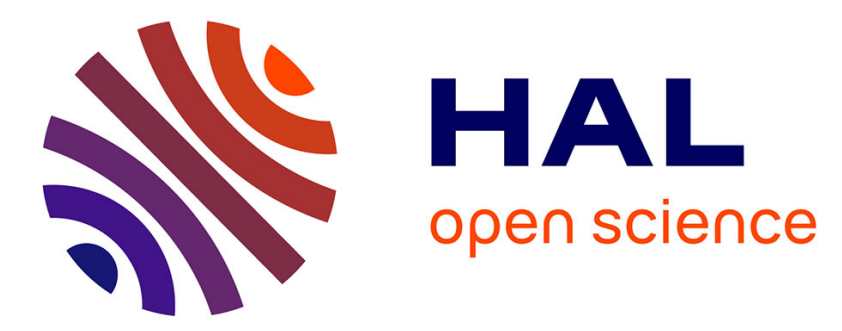

\title{
Annotated list of the entomophagous complex associated with pear psylla, Psylla pyri (L.) (Hom.: Psyllidae) in France
}

Franck Herard

\section{To cite this version:}

Franck Herard. Annotated list of the entomophagous complex associated with pear psylla, Psylla pyri (L.) (Hom.: Psyllidae) in France. Agronomie, 1986, 6 (1), pp.1-34. hal-00884845

\section{HAL Id: hal-00884845 \\ https://hal.science/hal-00884845}

Submitted on 1 Jan 1986

HAL is a multi-disciplinary open access archive for the deposit and dissemination of scientific research documents, whether they are published or not. The documents may come from teaching and research institutions in France or abroad, or from public or private research centers.
L'archive ouverte pluridisciplinaire HAL, est destinée au dépôt et à la diffusion de documents scientifiques de niveau recherche, publiés ou non, émanant des établissements d'enseignement et de recherche français ou étrangers, des laboratoires publics ou privés. 


\title{
Annotated list of the entomophagous complex associated with pear psylla, Psylla pyri (L.) (Hom. : Psyllidae) in France
}

Franck HERARD

European Parasite Laboratory, U.S.D.A., A.R.S., 13-17 rue de la Masse, Béhoust, F 78910 Orgerus

\begin{abstract}
Among the 56 beneficial insects collected and observed associated with pear psylla in France, 16 were abundant ; these arthropods included 2 parasitoids, Prionomitus mitratus (Dalman) and Trechnites psyllae (Ruschka) (Encyrtidae), and 14 predators, Anthocoris nemoralis (F.), A. nemorum (L.), Orius horvathi (Reuter), O. vicinus (Ribaut) (Het. : Anthocoridae) ; Heterotoma meriopterum (Scopoli), Campyloneura virgula (Herrich-Schäffer), Orthotylus nassatus (F.) (Het. : Miridae); Stethorus punctillum (Weise), Scymnus rubromaculatus (Goeze), S. subvillosus (Goeze), Coccinella septempunctata L. (Col. : Coccinellidae) ; Chrysoperla carnea (Stephens) (Neur : Chrysopidae) ; Coniopteryx borealis Tjeder (Neur. : Coniopterygidae) and the mite Allothrombium fuliginosum Hermann. All these species are polyphagous but only the first three are tied to pear psylla. It was shown that the environment of the orchards, comprising hawthorn and nettle, is a reservoir for the main pear psylla enemies. Other prey or hosts and host plants of these beneficial arthropods are cited from recent literature.
\end{abstract}

Additional key words : Pear trees, parasitoids, predators, worldwide literature review on the hosts and prey of the P. pyri natural enemies. (Hom. : Psyllidae) en France.

Parmi les 56 auxiliaires inventoriés dans le complexe biologique du psylle du poirier en France, 16 sont relativement abondants; ce sont 2 parasites, Prionomitus mitratus (Dalman) et Trechnites psyllae (Ruschka) (Encyrtidae), et 14 prédateurs, Anthrocoris nemoralis (F.), A. nemorum (L.), Orius horvathi (Reuter), O. vicinus (Ribaut) (Het.: Anthocoridae); Heterotoma meriopterum (Scopoli), Campyloneura virgula (Herrich-Schäffer), Orthotylus nassatus (F.) (Het. : Miridae) ; Stethorus punctillum (Weise), Scymnus rubromaculatus (Goeze), S. subvillosus (Goeze), Coccinella septempunctata L. (Col. : Coccinellidae) ; Chrysoperla carnea (Stephens) (Neur. : Chrysopidae) ; Coniopteryx borealis Tjeder (Neur. : Coniopterygidae) et l'acarien Allothrombium fuliginosum Hermann. Toutes ces espèces sont polyphages; seules les 3 premières citées sont étroitement liées au psylle du poirier. L'environnement immédiat des vergers, contenant aubépines et orties, s'est révélé être un réservoir des principaux ennemis du psylle du poirier. D'autres proies, hôtes et plante-hôtes de ces auxiliaires sont signalés d'après la littérature.

Mots clés additionnels : Poiriers, parasites, prédateurs, revue bibliographique mondiale sur les hôtes et les proies des ennemis naturels de $\mathbf{P}$. pyri.

\section{INTRODUCTION}

Psylla pyri (L.) (Hom. : Psyllidae) has long been known as the main pest of pear trees in France (BONNEMAISON \& MISSONNIER, 1956 ; GEOFFRION, 1981). Two other pear psyllids, Psylla pyrisuga Foerster and Psylla pyricola Foerster, are sporadically distributed in France and their damage is not significant (BONNEMAISON \& MisSONNIER, 1956 ; ATGER, 1978 ; GEOFFRION, 1981).
ATGER (1977) emphasized that the general upsurge of $P$. pyri populations was closely related to the increase in number of chemical applications made to control it. These treatments both induced increased resistance in the pest and also contributed to reduction of antagonistic fauna (ATGER, 1977, 1978, $1979 a, 1979 b$; ATGER et al., 1979). Failure of chemical control of $P$. pyri forced growers to reconsider theirmethods. Better knowledge of biology of the pest and of climatic, agricultural, ecological 
and human factors for regulation of its populations, led to use of an integrated control strategy. In France, it is mainly based on use of soft pesticides applied during low activity of predators and in such a manner as to protect the orchard's environment, which is an excellent reservoir for beneficial insects (ATGER et al., 1979).

Possibility of control of pear psylla by its natural enemies was noted in early studies on this pest in Europe (WILle, 1950 ; BONNEMAISON \& MisSONNIER, 1956; OVERMEER, 1961). The major natural enemies of pear psylla recorded in the literature in Europe are listed in table 1 , which completes and updates the inventory of PHILOGENE \& CHANG (1978).

In France, most authorities agree that only 3 species, Anthocoris nemoralis (F.) (Het. : Anthocoridae), Prionomitus mitratus (Dalman) and Trechnites psyllae (Ruschka) (Hym. : Encyrtidae) are closely tied to pear psylla and locally very effective in reducing it (FAUVEL \& ATGER, 1981 ; NGUYEN et al., 1981). However, when natural control of the psylla occurs, it cannot be done without the aid of many other species (Bouyjou et al., 1984 ; NGuYen \& Delvare, 1984) and we do not precisely know their relationship and impact on $P$. pyri (FAUVEL \& ATGER, 1981).

Our objective was to inventory parasitoids and predators of pear psylla in 3 orchards in France. By recording abundance of each species, we attempted to determine the most appropriate species for use in biological control.

\section{MATERIALS AND METHODS}

\section{A. The orchards}

We collected insects in a 7-hectare commercial orchard near Toulouse (Haute-Garonne) Southwestern France, in a 2-hectare abandoned plot in an orchard near Avignon (Vaucluse) Southeastern France, and in three $5000 \mathrm{~m}^{2}$ plots at Chanteloup-les-Vignes (Yvelines), Paris region.

At Avignon, the climate was mediterranean, moderated by the Rhone vailey. The climate was more humid at Toulouse and much more humid at Chanteloup-les-Vignes. In the orchards visited, pear varieties were "Yellow Williams" at Avignon, and "Red Williams", "Beurré-Hardy" and "Dr. Guyot" at Toulouse and at Chanteloup-les-Vignes. The environment of the orchards was especially rich in the 3 regions. At Avignon, the orchard was surrounded by rows of poplar and hedges of various shrubs, with hawthorn dominating. At Toulouse, the orchard was also surrounded by hawthorn hedges and was close to several groves of deciduous trees (Quercus, Carpinus, Ulmus). At Chanteloup-les-Vignes, the pear plots were situated in a polyculture truck farming plain, the irrigation canals of which are hedged with nettle, Urtica dioica $\mathrm{L}$. In southern France, hawthorn was mainly attacked by 2 psyllids, Psylla melanoneura Foerster and Psylla crataegi (Schrank); in northern France, it was also attacked by a third species Psylla peregrina Foerster. Nettle mainly was attacked by a psyllid, Trioza urticae L., by an aphid Microlophium evansi (Theobald) and by cicadellids, the most frequent of which were Eupteryx urticae (F.) and Eupteryx aurata (L.). We regularly explored the spontaneous vegetation surrounding the orchards to determine if it harbored alternate hosts and prey for pear psylla enemies.

\section{B. Methods}

Adult psyllids and larvae and adults of predators were collected by beating branches over a $0.5 \mathrm{~m}^{2}$ tray. Pear psylla nymphs and mummies were collected by cutting twigs bearing them. In the Iaboratory, mummies were isolated until parasites emerged. Living larvae were transferred to fresh ligneous pear twigs bearing tender leaves. The twigs, standing in aerated water, were placed in an incubator with 16 hour photoperiod and rather low constant temperature $\left(16{ }^{\circ} \mathrm{C}\right)$ to avoid wilting. Mummies which formed on these twigs were also isolated.

\section{RESULTS : ANNOTATED LIST OF SPECIES}

Species inventoried, their hosts or prey, host plants, abundance and localities of collections are listed in table 2.

\section{A. Parasitoids}

The polyphagous encyrtid, $P$. mitratus was one of the most frequent primary parasitoids found in our pear psylla and hawthorn psylla samples (table 2). This confirmed the high attraction of the latter plant as a reservoir for beneficial insects for natural control of pear psylla. $P$. mitratus hibernated as an adult (LAL, 1934) and attacked 4th and 5th instar psylla nymphs (NGUYEN et al., 1981). It occurred early in the year on the most precocious psyllae, $P$. melanoneura on hawthorn and $P$. pyrisuga on pear.

In Europe $P$. mitratus has often been noted on pear psylla (table 1), as sometimes being very efficacious against various psyllids (LAL, 1934; CARL \& ZWÖLFER, 1965 ; TALITSKII, 1966), and especially against $P$. pyri (NGUYEN et al., 1981 ; DELVARE et al., 1981). P. mitratus was recently redescribed by DELVARE et al. (1981) and its development and ethology studied in detail by Delvare (1977). It is holarctic in distribution (KROMBEIN et al., 1979) and has been noted from Canada (PHILOGENE \& CHANG, 1978), and in several states in the USA (JENSEN, 1957) on many species of psyllids.

According to FERRIERE (1961), Prionomitus tiliaris (Dalman) has rarely been noted in Europe ; HELLEN (1949) collected it in Finland from an unknown host. FERRIERE (1961) noted its strong affinity to $P$. peregrina. However, ARZONE (1979) and GIUNCHI (1980) mentioned $P$. tiliaris as a very efficacious parasitoid of $P$. pyri at Pimerolo, Italy. We personnally found it abundant on $P$. peregrina in the Paris region but also at Avignon on other hawthorn psyllids (table 2).

In abundance $T$. psyllae was the second primary parasitoid in our samples (table 2). It has been noted several times in Europe on pear psylla (table 1) as being responsible for a high rate of parasitism 


\section{TABLE 1}

Biocomplex of pear psylla in Europe (Literature review).

Complexe biologique des psylles du poirier en Europe (Revue bibliographique).

\begin{tabular}{cccc}
\hline \hline Order \& Family & Species or Genus & Location & References \\
\hline
\end{tabular}

\section{PARASITOIDS}

HYMENOPTERA

Encyrtidae

\section{DIPTERA}

Cecidomyiidae

\section{HYPERPARASITOIDS HYMENOPTERA}

Encyrtidae

Pteromalidae

Ceraphronoidea

\section{PREDATORS}

\section{HETEROPTERA}

Anthocoridae
Prionomitus mitratus (Dalman)

Psyllaephagus sp.

$\begin{array}{ll}\text { Aphidencyrtus cantabricus (Mercet) } & \text { Italy } \\ \text { Aphidencyrtus mamitus (Walker) } & \text { France } \\ \text { Aphidencyrtus taeniatus (Foerster) } & \text { Russia } \\ \text { Aphidencyrtus sp. } & \text { France } \\ \text { Marietta picta (André) } & \text { Russia } \\ \text { Encyrtus } \text { sp. } & \text { Russia } \\ \text { Pachyneuron aphidis } \text { Bouché } & \text { Russia } \\ & \text { France } \\ \text { Pachyneuron concolor } \text { (Foerster) } & \text { Italy } \\ & \text { France } \\ \text { Pachyneuron solitarium } \text { (Hartig) } & \text { Russia } \\ \text { Pachyneuron } \text { sp. } & \text { Scotland } \\ & \text { Italy } \\ & \text { France } \\ \text { Asaphes vulgaris Walker } & \text { Scotland } \\ \text { Lygocerus semiramosus } \text { Kieffer } & \text { Scotland } \\ \text { Lygocerus } \text { sp. } & \text { England } \\ & \text { France }\end{array}$

Endopsylla agilis de Meijere

Endopsylla sp.

Scotland
Switzerland
France

Prionomitus tiliaris (Dalman)

Trechnites psyllae (Ruschka)

Anthocoris gallarum-ulmi (DeGeer) Anthocoris nemoralis (F.)

\begin{tabular}{|c|c|}
\hline $\begin{array}{l}\text { Poland } \\
\text { Italy }\end{array}$ & $\begin{array}{l}\text { WOJNAROWSKA (1962). } \\
\text { VIDANO et al. }(1977-1978) \text {, AR } \\
\text { (1980). }\end{array}$ \\
\hline Italy & ARZONE (1979), GIUNCHI (1980 \\
\hline Germany & RUSCHKA (1923). \\
\hline France & $\begin{array}{l}\text { BONNEMAISON \& MISSONNIER } \\
\text { (1981). }\end{array}$ \\
\hline England & GEORGALA (1957). \\
\hline Russia & TALITSKII (1966). \\
\hline Italy & ARZONE (1979), GIUNCHI (1980 \\
\hline Italy & GolfFari (1937), GRANDI (1951 \\
\hline England & GEORGALA (1957) \\
\hline England & BAGNALL \& HARRISON (1924). \\
\hline Scotland & BARNES (1930), LAL (1934). \\
\hline Holland & BARNES $(1930)$ \\
\hline Switzerland & CARL (1969). \\
\hline Austria & CARL (1969). \\
\hline Germany & CARL (1969). \\
\hline France & CARL (1969). \\
\hline Italy & CARL (1969). \\
\hline Scotland & LAL (1934). \\
\hline
\end{tabular}

LAL (1934).

WILLE (1950).

Bonnemaison \& Missonnier (1956), Atger (1979b), Atger et al. (1979), NGuYen et al. (1981), Delvare (1977), Delvare et al. (1981), Ferriere (1926,

VidANo et al. (1977-1978), ARzone (1979), GiUNCHI

RUSCHKA (1923). (1981).

ARZONE (1979), GIUNCHI (1980) GolFARI (1937), GRANDI (1951).

Bagnall \& Harrison (1924).

(1930), LAL (1934).

CARL (1969).

\begin{tabular}{|c|c|}
\hline Yugoslavia & VRaBL \& Matis (1977). \\
\hline England & BRoNNIMANN (1964), Cranham (1980). \\
\hline Europe & CARL \& ZWOLFER (1965), IOBC (1980). \\
\hline Switzerland & $\begin{array}{l}\text { FiELDS \& BEIRNE (1973), KeIMER (1983), BAGGIOLINI } \\
\text { et al. (1979). }\end{array}$ \\
\hline Italy & $\begin{array}{l}\text { VIDANO et al. (1977-1978), ARZONE (1979), PEZZI } \\
\text { (1982). }\end{array}$ \\
\hline France & $\begin{array}{l}\text { ATGER (1979b), ATGER et al. (1979), NGUYen et al. } \\
\text { (1981), FaUvel \& ATGER (1981), GEOFFrion (1981). }\end{array}$ \\
\hline England & GEORGALA (1957), BRONNIMANN (1964). \\
\hline Poland & WOJNAROWSKA et al. (1960). \\
\hline Europe & CARL \& ZWOLFER (1965). \\
\hline France & $\begin{array}{l}\text { BONNEMAISON \& MISSONNIER (1956), NGUYEN et al. } \\
\text { (1981). }\end{array}$ \\
\hline Switzerland & SCHEURER et al. (1975). \\
\hline
\end{tabular}

Arzone (1979), Giunchi (1980).

NGUYEN et al. (1981).

TALITSKII (1966).

BONNEMAISON \& MisSONNIER (1956).

TALITSKII (1966)

YAKHONTOV (1929).

ARZONE (1979), GIUNCHI (1980).

TALITSKII (1966).

LAL (1934).

Golfari (1937), GRANDi (1951).

BONNEMAISON \& MisSONNIER (1956).

LAL (1934).

LAL (1934)

GEORGALA (1957).

BonNemaison \& Missonnier (1956). 
Table 1 (continued)

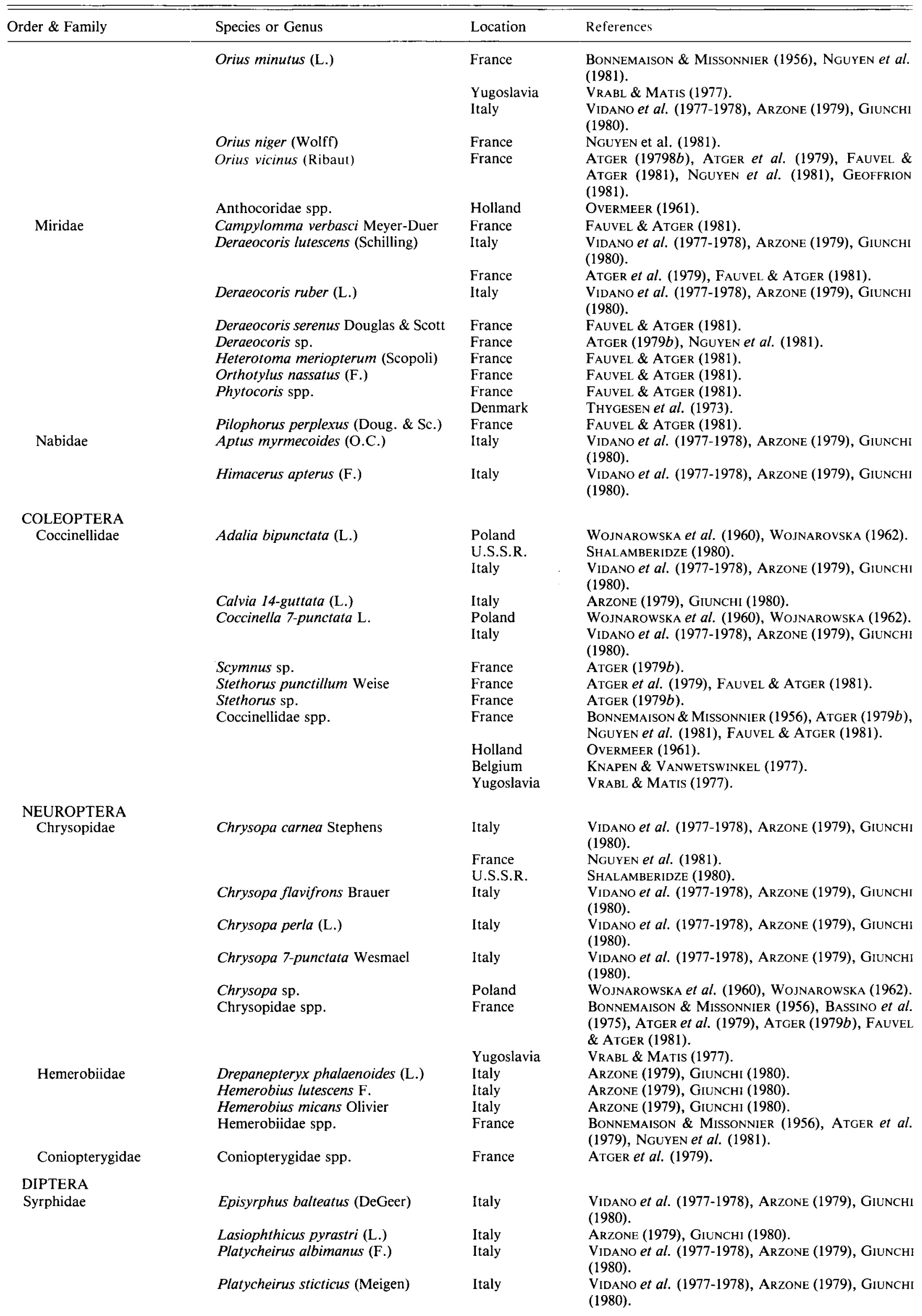


Table 1 (continued)

\begin{tabular}{|c|c|c|c|}
\hline Order \& Family & Species or Genus & Location & References \\
\hline & Sphaerophoria scripta (L.) & Italy & $\begin{array}{l}\text { VIDANO et al. (1977-1978), ARZONE (1979), GIUNCHI } \\
(1980) \text {. }\end{array}$ \\
\hline & Syrphidae spp. & France & $\begin{array}{l}\text { BONNEMAISON \& MiSSONNIER (1956), BASSINO et al. } \\
\text { (1975), ATGER et al. (1979), ATGER (1979b), NGUYEN } \\
\text { et al. (1981). }\end{array}$ \\
\hline & & Yugoslavia & VRABL \& MATIS (1977) \\
\hline \multicolumn{4}{|l|}{ ORTHOPTERA } \\
\hline Tettigoniidae & Meconema thalassinum (DeGeer) & Italy & ARZONE (1979), GIUNCHI (1980). \\
\hline Gryllidae & Oecanthus pellucens (Scopoli) & Italy & $\begin{array}{l}\text { VIDANO et al. (1977-1978), ARZONE (1979), GIUNCHI } \\
(1980) \text {. }\end{array}$ \\
\hline \multicolumn{4}{|l|}{ HYMENOPTERA } \\
\hline Formicidae & Formicidae spp. & France & NGUYEN et al. (1981). \\
\hline ARACHNIDA & & & \\
\hline Araneidae & Araneidae spp. & France & Fauvel \& Atger (1981). \\
\hline \multicolumn{4}{|l|}{ PATHOGEN } \\
\hline Entomophthoraceae & Entomophthora sp. & France & BONNEMAISON \& MisSONNIER (1956). \\
\hline & & Italy & $\begin{array}{l}\text { VIDANo et al. (1977-1978), Picco (1978), ARZONE } \\
\text { (1979), GiUnCHI (1980). }\end{array}$ \\
\hline
\end{tabular}

TABLE 2

Biocomplex of Psylla spp. on pear trees, hawthorn and nettle in France, by F. HERARD

Complexe biologique des psylles du poirier, aubépine et ortie en France, par F. HERARD

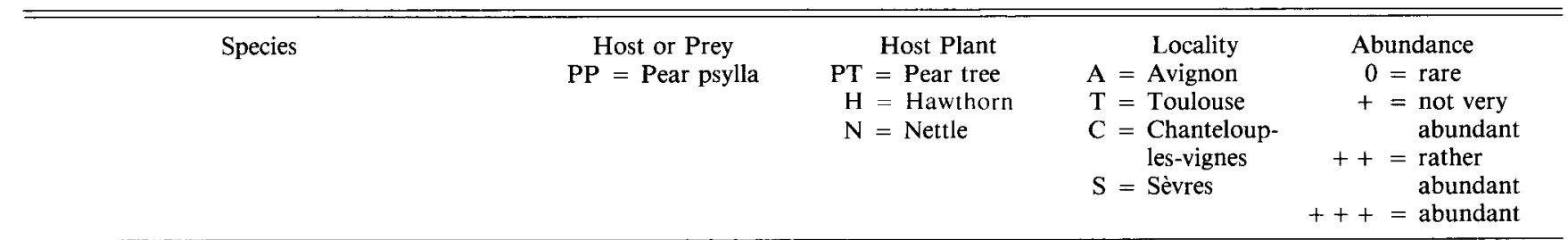

\section{PARASITOIDS}

HYMENOPTERA

Encyrtidae

Prionomitus mitratus (Dalman)

Prionomitus tiliaris (Dalman)

Trechnites psyllae (Ruschka)

Coccophagus? obscurus Westwood

\section{HYPERPARASITOIDS}

HYMENOPTERA

Encyrtidae

Aphidencyrtus mamitus (Walker)

Psylla pyri $(\mathrm{L}$.
Psylla pyrisuga Foerster
Psylla melanoneura
Foerster
Psylla peregrina
Foerster
Psylla crataegi
(Schrank)
P. melanoneura
P. peregrina
P. crataegi
P. pyri
P. pyrisuga
P. crataegi
P. peregrina

PT

PT

$\mathbf{H}$

H

$\mathrm{H}$

$\mathrm{H}$

$\mathrm{H}$

PT

PT

$\mathrm{H}$

$\mathrm{H}$

$\begin{array}{ll}\text { A, T } & ++ \\ \text { A, T } & 0 \\ \text { A } & + \\ \text { S } & ++ \\ & \\ \text { A } & +++ \\ \text { A } & + \\ \text { S } & +++ \\ \text { A } & + \\ \text { A, T, C } & ++ \\ \text { A, T } & 0 \\ \text { A } & + \\ \text { S } & 0\end{array}$

$P$. mitratus
in $P$. pyri
in $P$. pyrisuga
in $P$. peregrina
in $P$. crataegi
$P$. tiliaris
in $P$. peregrina
$T$. psyllae
in $P$. pyri
in $P$. pyrisuga
$P$. mitratus in $P$. pyri
$P$. tiliaris
in $P$. peregrina

PT

PT

$\mathrm{H}$

$\mathrm{H}$

$\mathrm{H}$

PT

PT

PT

H
A, T

A, $T$

$\mathrm{S}$

A

S

A, T, C

A, $T$

A

S

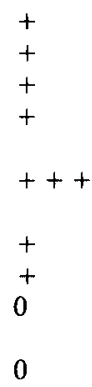


Table 2 (continued)

\begin{tabular}{|c|c|c|c|c|}
\hline Species & $\begin{array}{c}\text { Host or Prey } \\
\mathrm{PP}=\text { Pear psylla }\end{array}$ & $\begin{aligned} & \text { Host Plant } \\
\text { PT } & =\text { Pear tree } \\
\mathrm{H} & =\text { Hawihorn } \\
\mathrm{N} & =\text { Nettle }\end{aligned}$ & $\begin{aligned} & \text { Locality } \\
\mathrm{A} & =\text { Avignon } \\
\mathrm{T} & =\text { Toulouse } \\
\mathrm{C} & =\text { Chanteloup- } \\
& \text { les-vignes } \\
\mathrm{S} & =\text { Sèvres }\end{aligned}$ & $\begin{array}{cc}\text { Abundance } \\
0=\text { rare } \\
+=\text { not very } \\
\text { abundant } \\
++=\begin{array}{l}\text { rather } \\
\text { abundant }\end{array} \\
++=\text { abundant }\end{array}$ \\
\hline
\end{tabular}

Pteromalidae

Pachyneuron concolor (Foerster)

(= muscarum (L.))

Hyperimerus pusillus (Walker)*

Coruna clavata Walker

Cynipoidea

Alloxystidae

Dilyta subclavata Foerster

Ceraphronoidea

Megaspilidae

Dendrocerus psyllarum Dessart**

P. tiliaris

in $P$. peregrina

P. mitratus

in $P$. peregrina

in $P$. crataeg

in $P$. pyri

$P$. tiliaris

in $P$. peregrina

P. tiliaris

in $P$. peregrina
P. mitratus in $P$. pyri

$\mathrm{H}$

H

PT

$\mathrm{H}$

$\mathrm{H}$

PT

PT

PP

$P$. peregrina

P. crataegi

PP

Trioza urticae $\mathrm{L}$.

$\mathrm{PP}$

PP

$\mathrm{PP}$

$P$. peregrina

PP

P. peregrina

$\mathrm{PP}$

T. urticae

PP

PP

Orius majusculus (Reuter)

Temnostethus pusillus

(Herrich-Schäffer)

Cardiastethus fasciiventris (Garb.)

Miridae

Heterotoma meriopterum (Scopoli)

Campyloneura virgula (Herrich-Schäffer)

Orthotylus nassatus (F.)

Deraeocoris lutescens (Schilling)

Deraeocoris ruber (L.)

Pilophorus perplexus

(Douglas \& Scott)

Pilophorus gallicus Remane

Pilophorus clavatus (L.)

Mimocoris rugicollis (Costa)

Psallus ambiguus (Fallen)

Phytocoris longipennis Flor

Phytocoris ulmi (L.)

Nabidae

Himacerus apterus (L.)

Nabis ferus (L.)

Nabis punctatus Costa
PP

Psocidae, Psylla?

PP

P. crataegi

P. peregrina

T. urticae

PP

$P$. peregrina

P. crataegi

PP

P. crataegi

PP

P. crataegi

PP

PP

PP

PP

PP

PP

P. peregrina

PP

PP

PP

PP

PP

$\begin{array}{ll}\text { S } & 0 \\ \text { A } ~ & 0 \\ \text { A, T, C } & + \\ \text { S } & 0 \\ \text { S } & \end{array}$

A, $T$

0

S

0

$\begin{array}{ll}\text { A, T, C } & +++ \\ \text { S } & ++ \\ \text { A } & + \\ \text { C } & ++ \\ \text { C, S } & + \\ \text { C } & 0 \\ \text { A, T, C } & +++ \\ \text { A, T, C } & ++ \\ \text { S } & + \\ \text { A, T, C } & + \\ \text { S } & + \\ \text { T, C } & + \\ \text { T, C } & + \\ \text { A, T, C } & 0 \\ \text { A, C } & 0 \\ \text { T } & \\ \text { A, T } & 0 \\ \text { S } & 0\end{array}$

$\begin{array}{ll}\mathrm{A}, \mathrm{T}, \mathrm{C} & +++ \\ \mathrm{A} & ++ \\ \mathrm{S} & + \\ \mathrm{S} & ++\end{array}$

$\begin{array}{ll}\text { A, T, C } & +++ \\ \text { S } & + \\ \text { A } & + \\ \text { A, T } & +++ \\ \text { A } & + \\ \text { A, T } & + \\ \text { A } & 0 \\ \text { C } & 0\end{array}$

$\begin{array}{ll}\text { A, T } & + \\ \text { A } & 0 \\ \text { T } & + \\ \text { A } & 0 \\ \text { T } & 0 \\ \text { S } & 0 \\ \text { T, C } & 0 \\ \text { T } & 0 \\ & \\ \text { T, C } & 0 \\ \text { T } & 0 \\ \text { T } & 0\end{array}$

* First host record ; ** New species ; ? Species = means that the identification is not certain, because the specimen is aberrant, usually too small, with unevident characters. 
Table 2 (continued)

\begin{tabular}{|c|c|c|c|c|}
\hline Species & $\begin{array}{c}\text { Host or Prey } \\
\text { PP = Pear psylla }\end{array}$ & $\begin{aligned} & \text { Host Plant } \\
\text { PT } & =\text { Pear tree } \\
\mathrm{H} & =\text { Hawthorn } \\
\mathrm{N} & =\text { Nettle }\end{aligned}$ & $\begin{aligned} & \text { Locality } \\
\mathrm{A} & =\text { Avignon } \\
\mathrm{T} & =\text { Toulouse } \\
\mathrm{C} & =\text { Chanteloup- } \\
& \text { les-vignes } \\
\mathrm{S} & =\text { Sèvres }\end{aligned}$ & $\begin{array}{c}\text { Abundance } \\
0=\text { rare } \\
+=\text { not very } \\
\text { abundant } \\
++=\begin{array}{l}\text { rather } \\
\text { abundant }\end{array} \\
+++=\text { abundant }\end{array}$ \\
\hline \multicolumn{5}{|l|}{ COLEOPTERA } \\
\hline \multicolumn{5}{|l|}{ Coccinellidae } \\
\hline Stethorus punctillum (Weise) & Mites, Psylla? & PT & A & $+t+$ \\
\hline Scymnus rubromaculatus (Goeze) & $\begin{array}{l}\text { PP } \\
\text { P. crataegi }\end{array}$ & $\begin{array}{l}\mathrm{PT} \\
\mathrm{H}\end{array}$ & $\begin{array}{l}\mathrm{A}, \mathrm{T} \\
\mathrm{A}\end{array}$ & $\begin{array}{l}+++ \\
+\end{array}$ \\
\hline Scymnus subvillosus (Goeze) & PP & $\mathrm{PT}$ & A & +++ \\
\hline Scymnus interruptus (Goeze) & PP & $\mathrm{PT}$ & A & 0 \\
\hline \multirow[t]{2}{*}{ Rhyzobius chrysomeloides (Herbst) } & $\mathrm{PP}$ & $\mathbf{P T}$ & A & 0 \\
\hline & P. peregrina & $\mathrm{H}$ & $\mathrm{S}$ & 0 \\
\hline \multirow[t]{2}{*}{ Clitostethus arcuatus (Rossi) } & White flies & $\mathbf{H}$ & S & + \\
\hline & $P$. peregrina & $\mathrm{H}$ & $\mathrm{S}$ & 0 \\
\hline Adalia bipunctata (L.) & $\mathrm{PP}$ & PT & $\mathrm{A}, \mathrm{T}, \mathrm{C}$ & + \\
\hline Synharmonia conglobata (L.) & PP & PT & A, $\mathrm{T}$ & 0 \\
\hline Synharmonia lyncea Olivier & PP & PT & $\mathrm{T}$ & 0 \\
\hline Propylea quattuordecimpunctata (L.) & PP & PT & $\mathrm{A}, \mathrm{T}$ & 0 \\
\hline Coccinella septempunctata $\mathrm{L}$. & PP & PT & $\mathrm{A}, \mathrm{T}$ & ++ \\
\hline Chilocorus renipustulatus (Scriba) & PP & PT & $\mathrm{T}$ & 0 \\
\hline Coccinula quatuordecimpustulata (L.) & PP & PT & $\mathrm{T}$ & 0 \\
\hline Thea vigintiduopunctata (L.) & PP & PT & A & + \\
\hline \multicolumn{5}{|l|}{ Carabidae } \\
\hline Demetrias atricapillus (L.) & $\mathrm{PP}$ & PT & $\mathrm{A}, \mathrm{T}$ & + \\
\hline \multicolumn{5}{|l|}{ NEUROPTERA } \\
\hline \multicolumn{5}{|l|}{ Chrysopidae } \\
\hline Chrysoperla carnea (Stephens) & PP & PT & A, T, C & +++ \\
\hline Anisochrysa prasina (Burmeister) & PP & $\mathbf{P T}$ & A & 0 \\
\hline Anisochrysa picteti (McLachlan) & PP & $\mathrm{PT}$ & A & 0 \\
\hline \multicolumn{5}{|l|}{$\begin{array}{l}\text { Hemerobiidae } \\
\text { Hen }\end{array}$} \\
\hline \multirow[t]{2}{*}{ Hemerobius humulinus $\mathrm{L}$. } & PP & PT & A, $\mathrm{T}$ & + \\
\hline & P. crataegi & $\mathrm{H}$ & A & + \\
\hline Wesmaelius subnebulosa (Stephens) & PP & PT & A & 0 \\
\hline Sympherobius pygmaeus (Rambur) & PP & PT & A & 0 \\
\hline \multicolumn{5}{|l|}{ Coniopterygidae } \\
\hline \multirow[t]{3}{*}{ Coniopteryx borealis Tjeder } & PP & PT & A, T & ++ \\
\hline & $P$. peregrina & $\mathrm{H}$ & $\mathrm{S}$ & + \\
\hline & $P$. crataegi & $\mathbf{H}$ & A & + \\
\hline \multicolumn{5}{|l|}{ DIPTERA } \\
\hline \multicolumn{5}{|l|}{ Syrphidae } \\
\hline Meliscaeva auricollis (Meigen) & PP & PT & $\mathbf{T}$ & + \\
\hline Syrphus vitripennis (Meigen) & PP & PT & $\mathrm{T}$ & + \\
\hline Episyrphus balteatus (De Geer) & PP & PT & $\mathrm{T}$ & + \\
\hline \multicolumn{5}{|l|}{ ACARI } \\
\hline Anystis sp. & PP & PT & $\mathrm{A}, \mathrm{T}$ & + \\
\hline Allothrombium fuliginosum Hermann & PP & PT & A, $\mathrm{T}$ & ++ \\
\hline \multicolumn{5}{|l|}{ PATHOGEN } \\
\hline Entomophthora sp. & $P \cdot$ peregrina & $\mathrm{H}$ & $\mathrm{S}$ & 0 \\
\hline
\end{tabular}

(TALITSKII, 1966). We also obtained it from $P$. crataegi nymphs at Avignon in 1981. In contrast to P. mitratus, T. psyllae generally were abundant in late summer and in autumn. It hibernated in the larval stage inside its mummified host. In early winter, we observed that $P$. pyri nymphs parasitized by T. psyllae moved downward on pear trees, 2 to 3 meters from the crown. There they stopped in crevices of the bark and mummified. We trapped them in large numbers using undulated cardboard traps placed at the base of the tree. This implies that the parasitoid can influence the behavior of its host in autumn thus affording it a favorable hibernating site at the moment of host mummification. In contrast, we found that in autumn unparasitized 5th instar nymphs abandoned leaves which were going to fall and come to rest on twigs 10 to $30 \mathrm{~cm}$ from their original feeding site. There they moult to become adults and to overwinter. Interestingly, in summer, the parasitized nymphs of pear psylla did not mummify further than $30 \mathrm{~cm}$ from their feeding site.

T. psyllae was introduced several times in California between 1965 and 1968 (CLAUSEN, 1978) to contribute to the control of $P$. pyricola. This encyrtid has also been found in Ontario, Canada, where its introduction probably was fortuitous.

Specimens of Coccophagus (?) obscurus Westwood which we obtained from $P$. peregrina were considered by Dr. BOUCEK (pers. com.), who identified them, most probably as primary parasitoids of this psyllid. 
This encyrtid has been recorded as a primary parasitoid of the coccid, Euphilippia olivina Berl. \& Silv., on olive in Italy (SCALTRITI, 1982).

\section{B. Hyperparasitoids}

In our samples of pear and hawthorn psyllid mummies, the encyrtids, $P$. mitratus, $P$. tiliaris and T. psyllae, were sometimes parasitized by Aphidencyrtus mamitus (Walker) (table 2). According to NGUYEN et al. (1981), this encyrtid can attack 2nd and 5 th instar larvae and prepupae of $P$. mitratus and $T$. psyllae inside $P$. pyri. STARY (1970) obtained A. mamitus from the sycamore aphid Drepanosiphum platanoides (Schrank) in Czechoslovakia.

We obtained Aphidencyrtus (?) taeniatus (Foerster) from $P$. pyri nymphs parasitized by $P$. mitratus. In the USSR, TALITSKII (1966) noted $A$. taeniatus as a primary and occasionally a secondary parasitoid of P. pyri.

We reared Aphidencyrtus (?) aphidivorus (Mayr) from $P$. peregrina parasitized by $P$. tiliaris. From references recorded in table $3, A$. aphidivorus is holarctic in distribution and generally collected from aphids, sometimes as a primary parasitoid but most often as a hyperparasitoid.
Among the pteromalid hyperparasitoids found in our pear and hawthorn psyllid samples, Pachyneuron concolor (Foerster) (= muscarum (L.)) was the commonest (table 2). It was recorded in 1939 from $P$. peregrina (GRAHAM, 1969), very probably as a hyperparasitoid of this psyllid. NGUYEN et al. (1981) observed it as an ectoparasitoid of 5th instar larvae, prepupae and pupae of $P$. mitratus and $T$. psyllae inside $P$. pyri mummies. $P$. concolor is polyphagous and was sometimes mentioned as a primary parasitoid (table 4). More often it has been a hyperparasitoid and sometimes as a tertiary parasitoid on members of its own species, as well as on various other chalcidoids that have developed as secondary parasitoids in an encyrtid host (ROSEN \& KFIR, 1983).

We obtained Hyperimerus pusillus (Walker) from $P$. peregrina nymphs parasitized by $P$. tiliaris. According to Dr. BOUCEK (pers. com.) who identified this Pteromalid, it is a first host record. Biology of H. pusillus is unknown (GRAHAM, 1969), but it was collected in Britain, Sweden, Czechoslovakia, Yugoslavia, and now in France. A related nearctic species, Hyperimerus corvus Girault, was mentioned as a parasitoid of Chrysopa sp., Hemerobius sp. and Sympherobius sp., closely associated with Pseudococcus in its native environment (KROMBEIN et al., 1979).

\section{TABLE 3}

Host of Aphidencyrtus aphidivorus (Mayr) noted in recent literature.

Hôtes d'A. aphidivorus signalés récemment dans la littérature.

\begin{tabular}{|c|c|c|c|c|}
\hline Primary host & Secondary host & Host plant & Location & References \\
\hline \multicolumn{5}{|l|}{ Aphids } \\
\hline Aphis gossypii Glover & $\ldots \ldots \ldots \ldots, \ldots, \ldots$ & cotton & $\begin{array}{l}\text { Bulgaria } \\
\text { India }\end{array}$ & $\begin{array}{l}\text { Radev (1968). } \\
\text { Palaniswami \& Pillai } \\
\text { (1980). }\end{array}$ \\
\hline Aphis fabae Scopoli & & broad bean & Iraq & SELIM (1977). \\
\hline Aphis pomi De Geer & $\ldots \ldots \ldots \ldots \ldots \ldots \ldots$ & apple & India & НАYАT $(1981)$ \\
\hline Aphis craccivora Koch & $\ldots \ldots \ldots \ldots \ldots \ldots \ldots \ldots \ldots \ldots \ldots \ldots$ & leguminous crops & Pakistan & HAMID et al. (1977). \\
\hline Uroleucon compositae (Theobald) & & safflower & India & $\begin{array}{l}\text { THONTADARYA et al. } \\
\text { (1976). }\end{array}$ \\
\hline Rhopalosiphum maidis (Fitch) & $\cdots \cdots$ & sorghum & India & RADKE \& BARWAD (1978). \\
\hline Hymenoptera & Aphids & & & \\
\hline$?$ & $\begin{array}{l}\text { Toxoptera aurantii } \\
\text { Boyer de Fonscolombe }\end{array}$ & citrus & Greece & SANTAS (1979). \\
\hline ? & Diuraphis noxia (Mordvilko) & barley, wheat & U.S.S.R. & BEREST $(1980 a)$. \\
\hline ? & Schizaphis graminum (Rondani) & barley, wheat & U.S.S.R. & BEREST $(1980 a)$. \\
\hline$?$ & A. gossypii & cotton & China & SHI (1982). \\
\hline Aphelinus flavus Thomson & $\begin{array}{l}\text { Drepanosiphum platanoides } \\
\text { (Schrank) }\end{array}$ & sycamore & Scotland & HAMILTON (1973). \\
\hline Aphelinus abdominalis (Dalman) & Metopolophium dirhodum (Walker) & Phalaris sp. & Argentina & BotTo (1981). \\
\hline Aphelinus nigritus Howard & R. maidis & sorghum & U.S.A. & $\begin{array}{l}\text { SUMMY et al. (1979), } \\
\text { ARCHER et al. (1974), } \\
\text { JACKSON et al. (1970). }\end{array}$ \\
\hline Aphelinus varipes (Foerster) & R. maidis & sorghum & U.S.A. & $\begin{array}{l}\text { ARCHER et al. (1974), } \\
\text { JACKSON et al. (1970). }\end{array}$ \\
\hline $\begin{array}{l}\text { Aphidius colemani Viereck } \\
\text { Aphidius smithi }\end{array}$ & S. graminum & sorghum & Brazil & GRAVENA (1982). \\
\hline Sharma \& Subba Rao & Acyrthosiphon pisum (Harris) & lucerne, red clover & U.S.A. & PASS \& PARR (1971). \\
\hline Diaeretiella rapae (Mc Intosh) & S. graminum & sorghum & $\begin{array}{l}\text { Brazil } \\
\text { U.S.A. }\end{array}$ & $\begin{array}{l}\text { GRAVENA (1979). } \\
\text { WALKER et al. (1973). }\end{array}$ \\
\hline Lysiphlebus testaceipes (Cresson) & S. graminum & sorghum & U.S.A. & $\begin{array}{l}\text { JACKSON et al. (1970), } \\
\text { WALKER et al. (1973), } \\
\text { ARCHER et al. (1974), } \\
\text { SuMMY et al. (1979), }\end{array}$ \\
\hline
\end{tabular}


TABLE 4

Hosts of Pachyneuron concolor (Foerster) noted in recent literature.

Hôtes de $\mathrm{P}$. concolor signalés récemment dans la littérature.

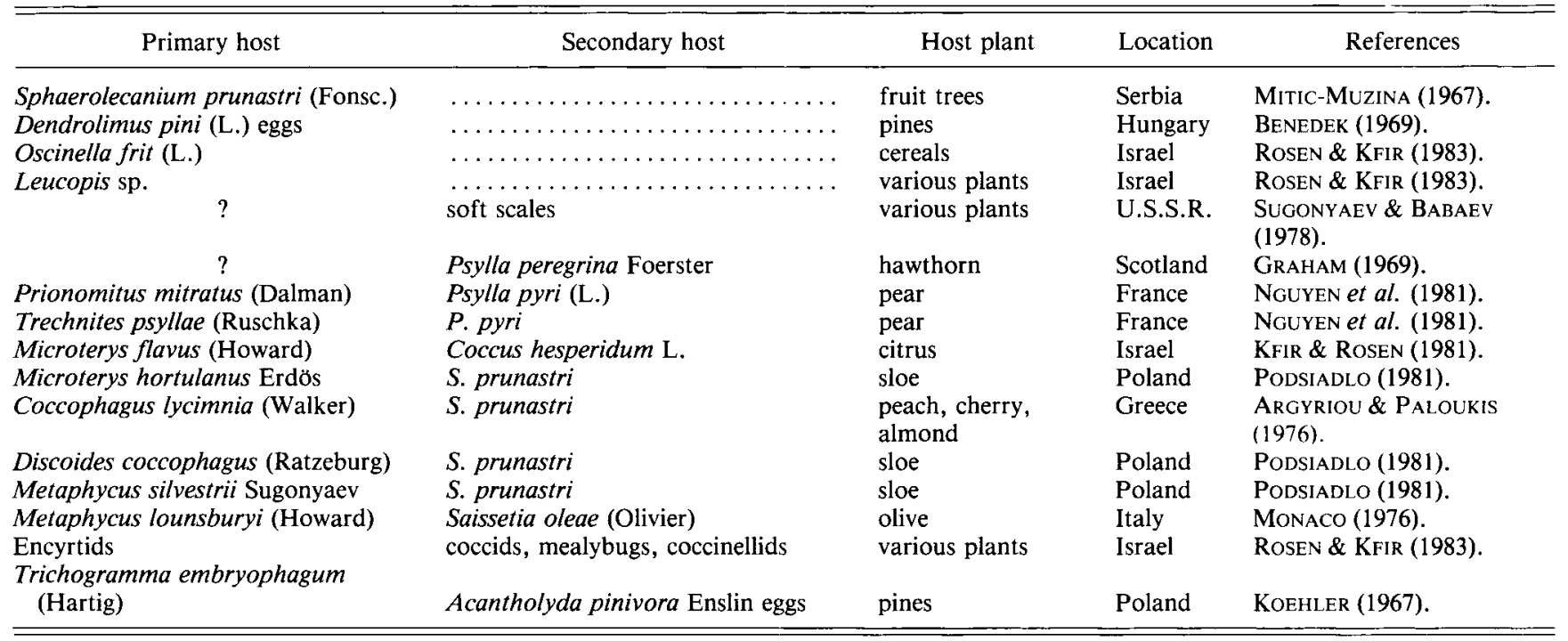

We found Coruna clavata Walker as a hyperparasite of $P$. peregrina (parasitized by $P$. tiliaris) in the Paris region. According to GRAHAM (1969), this Pteromalid is widely distributed in Europe, USSR and North America. It generally has been noted as a hyperparasite of aphids through various species of Aphidiidae (Shands et al., 1965 ; GraHAM, 1969 ; DEAN, 1974 ; HAMILTON, 1973 ; JONES, 1979 ; KROMBEIN et al., 1979).

We found Dilyta subclavata Foerster as a hyperparasite of $P$. pyri through $P$. mitratus in Southern France. Nothing is known on this species. Other species belonging to the same family Alloxystidae parasitize braconid or chalcidoid primary parasites of aphids or other Homoptera (KROMBEIN et al., 1979).

From some of the $P$. peregrina nymphs (parasitized by $P$. tiliaris) collected in the Paris region, a new species of Ceraphronoidea (Megaspilidae) emerged which DESSART described and named Dendrocerus psyllarum (DESSART, 1983). Specimens previously obtained from $P$. pyri mummies at Versailles by BONNEMAISON \& MisSONNIER in 1956, were also used by DESSART for describing the species. Other Dendrocerus were already mentioned as hyperparasitoids of psyllids ; in Britain, Lygocerus ( = Dendrocerus) semiramosus Kieffer (LAL, 1934), a hyperparasitoid of $P$. peregrina through $P$. mitratus and Lygocerus $\mathrm{sp}$. was obtained from 5 th instar nymphs of $P$. pyricola (GEORGALA, 1957). In France, BONNEMAISON \& MISSONNIER (1956) recorded Lygocerus sp. from $P$. pyri mummies.

\section{Predators}

\section{Heteroptera}

\section{a) Anthocoridae}

The anthocorid $A$. nemoralis was the most abundant predator in all the orchards infested with
$P$. pyri which we examined and the most efficacious enemy of this pest. A literature review (table 1) showed that $A$. nemoralis is a permanent component of the biocomplex of pear psylla in Europe. It is a very polyphagous predator, but its most common prey are psyllids (ANDERSON, 1962a). It preferably frequents the tree and shrub stratum and a few conifers, but over all, it prefers deciduous species, mainly fruit trees (PERICART, 1972). Its distribution includes Europe and the mediterranean countries (PERICART, 1972). Its main prey other than pear psylla, based on recent literature, are listed in table 5. A. nemoralis was introduced in 1963 in North America in a pear orchard infested with $P$. pyricola near Summerland, British Columbia, where its establishment was successful (McMULLEN \& JONG, 1967b; FIELDS \& BEIRNE, 1973; ClausEN, 1978). Release in other locations resulted in establishment as well, i.e. Ontario (KeLtON, 1978 ; HAGLEY \& SiMPSON, 1983). $A$. nemoralis has dispersed and replaced the native predators, Anthocoris antevolens White and Anthocoris melanocerus Reuter as the most common anthocorid predator in some orchards (FIELDS \& BEIRNE, 1973).

We did not observed Anthocoris nemorum (L.) in pear orchards in southern France, but it was abundant in the Paris region, especially in autumn. Otherwise, we found it abundantly in spring and summer in the herbaceous stratum, especially on nettle close to orchards. That led us to study some components of its ecology and ethology to evaluate its relationship to pear psylla and its potential as a biological control agent against this pest. These results were presented in another paper (HERARD \& CHEN, 1985) and complete information already furnished by HILL (1957), ANDERSON (1962a, $b, c)$, COLLYER (1967), RUSSEL (1970, 1972), PARKER (1975), EVANS (1976a), CAMPBELL (1977), LAUENSTEIN $(1976,1977,1980)$ on this predator. 
TABLE 5

Prey of Anthocoris nemoralis (F.), other than pear psylla, noted in recent literature.

Proies d'A. nemoralis (sauf les psylles du poirier), signalées récemment dans la littérature.

\begin{tabular}{|c|c|c|c|}
\hline Prey & Host plants & Location & References \\
\hline \multicolumn{4}{|l|}{ Aphids } \\
\hline Phorodon humuli (Schrank) & hops & England & $\begin{array}{l}\text { AVELING }(1981 a, 1981 b) \text {, CAMPBELl } \\
(1977,1978) .\end{array}$ \\
\hline Eriosoma ulmi (L.) & elm & Poland & JANISZEWSKA-CICHOCKA (1971). \\
\hline Brevicoryne brassicae (L.) & cabbage & Bulgaria & TSACHEV (1972). \\
\hline \multicolumn{4}{|l|}{ Cecidomyiids } \\
\hline Dasineura mali (Kieffer) & apple & Germany & CARL (1980). \\
\hline Macrolabis sp. & apple & Germany & CARL (1980). \\
\hline \multicolumn{4}{|l|}{ Aleurodids } \\
\hline Siphoninus phillyreae (Haliday) & pear & Bulgaria & Pelov \& Trenchev (1973). \\
\hline & hawthorn & Bulgaria & Pelov \& Trenchev (1973). \\
\hline \multicolumn{4}{|l|}{ Lepidoptera } \\
\hline Leucoptera scitella (Zeller) & apple & Bulgaria & IVANOV (1978). \\
\hline Phyllonorycter blancardella $(\mathrm{F})$. & apple & Bulgaria & IVANOV (1978). \\
\hline Phyllonorycter corylifoliella (Herbst) & apple & Bulgaria & IVANOV (1978). \\
\hline Stigmella malella (Sainton) & apple & Bulgaria & IVANOV (1978). \\
\hline \multirow[t]{2}{*}{ Cydia pomonella (L.) } & apple & England & GLEN (1975). \\
\hline & & Bulgaria & KARADZHOV (1973a). \\
\hline \multicolumn{4}{|l|}{ Mites } \\
\hline \multirow[t]{3}{*}{ Panonychus ulmi (Koch) } & apple & England & SOLOMON (1982). \\
\hline & & Bulgaria & KARADZHOV $(1973 b)$. \\
\hline & & Poland & KorCz (1971). \\
\hline Bryobia rubrioculus (Scheuten) & apple & Poland & Korcz (1971). \\
\hline Tetranychus urticae Koch & apple & Poland & KorCz (1971). \\
\hline Tetranychus viennensis Zacher & apple & Poland & KORCZ (1971). \\
\hline Tetranychids & various plants & Bulgaria & BALEVSKI (1977). \\
\hline \multicolumn{4}{|l|}{ Various prey } \\
\hline aphids, psyllids, thrips, noctuid larvae, mites & apple & Sweden & NORDLANDER (1977). \\
\hline & various plants & Turkey & ONDER (1982). \\
\hline
\end{tabular}

A. nemorum is distributed throughout Europe, Russia, Siberia (except the steppes regions), and China. However, it is rare in the mediterranean region (PERICART, 1972). It is an ubiquitous species and very eclectic in the choice of its prey (PERICART, 1972). Although it accepts many prey, there are great differences among them in nutritive value for the predator (HERARD \& CHEN, 1985). A. nemorum has sometimes been noted on pear (table 1), and a long list of its prey was prepared by COLLYER (1967). Table 6 presents a list of prey besides pear psylla, as noted in the literature since 1965. Unsuccessful attempts to introduce $A$. nemorum into North America for control of $P$. pyricola were made in 1962 (CLAUSEN, 1978). New attempts were made in 1982 and 1983 in the state of Washington (USA), using predators reared and supplied by us. Results of these U.S. releases to control the pest are yet unknown, but our observations on this predator lead us to believe that it cannot be an efficient species against pear psylla (HERARD \& CHEN, 1985).

We collected very small numbers of the predator Anthocoris confusus Reuter on pear trees in the Paris region (table 2 ). This anthocorid has been noted from Europe, Siberia and Japan, but in France, it is most common in the northern half of the country, occurring on deciduous and fruit trees (PERICART, 1972). It was observed mainly as a predator of aphids, notably of $D$. platanoides on sycamore in Scotland (RUSSEL, 1970 ; DIXON \& RUSSEL, 1972 ; HAMILTON,
1973) ; in England, as a predator of Acyrtosiphon pisum (Harris) (ELLIOTT, 1970) and of Aulacorthum circumflexum (Buckton) (EvANS, 1976b,c, $d, e)$ on broad bean, and of Phorodon humuli (Schrank) on hops (AvELING, 1981b). In France, it has been listed as a predator of various prey on apple (FAUVEL, $1974 a$ ).

Among the 6 species of Orius inventoried in pear orchards, 3 were abundant, Orius horvathi (Reuter), Orius vicinus (Ribaut), Orius minutus (L.), and 3 were rare, Orius niger (Wolff), Orius laevigatus (Fieber) and Orius majusculus (Reuter).

We observed $O$. horvathi in high numbers in the pear psylla infested orchards we examined (table 2). According to FAUVEL (1974a), this anthocorid seems more tied to phytophagous mites than to psyllids and aphids in orchards. However, it has been noted as a predator of Aphis pomi De Geer (STRAWINSKI, in PERICART, 1972), and of aphids, psyllids, thrips, noctuid larvae, and mites in Turkey (ONDER, 1982). Distribution of $O$. horvathi is throughout the western and eastern palearctic regions (PERICART, 1972) to China (ZHENG, 1982).

We found $O$. vicinus associated with $P$. pyri in all orchards examined and with $P$. peregrina in the Paris region, as well (table 2). This anthocorid was previously mentioned as being associated with pear psylla (table 1), but it accepts many other prey, from many plants (PERICART, 1972). O. vicinus and A. nemoralis are the most common predator of 
TABLE 6

Prey of Anthocoris nemorum (L.) other than pear psylla, noted in the literature since 1965.

Proies d'A. nemorum (sauf les psylles du poirier), signalées dans la littérature depuis 1965.

\begin{tabular}{|c|c|c|c|}
\hline Prey & Host plants & Location & References \\
\hline \multicolumn{4}{|l|}{ Aphids } \\
\hline Drepanosiphum platanoides (Schrank) & sycamore & Scotland & $\begin{array}{l}\text { Russel (1970), DixON \& Russel (1972), } \\
\text { HAMilton (1973). }\end{array}$ \\
\hline Phorodon humuli (Schrank) & hops & England & $\begin{array}{l}\text { CAMPBell }(1977,1978) \text { Aveling } \\
(1981 b), \text { PARKER }(1981)\end{array}$ \\
\hline Aphis pomi DeGeer & apple & Germany & ASCARI (1966). \\
\hline \multirow[t]{2}{*}{ Aphids spp. } & apple & France & FAUVEL $(1974 a)$ \\
\hline & fruit trees & Poland & WIACKOWSKI \& WIACKOWSKA (1968). \\
\hline \multirow[t]{2}{*}{ Acyrtosiphon pisum (Harris) } & broad bean & England & ELLIOTT (1970). \\
\hline & pea & England & Evans $(1976 a)$ \\
\hline \multirow[t]{2}{*}{ Aphids spp. } & Brussels sprouts & England & Sмiтн (1976). \\
\hline & 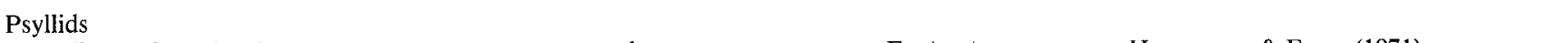 & France & BONNEMAISON (1971). \\
\hline Psyllopsis fraxini (L.) & ash & England & HodKINSON \& FLINT (1971). \\
\hline \multicolumn{4}{|l|}{ Aleurodids } \\
\hline Trialeurodes vaporariorum (Westwood) & tomato, cucumber & Sweden & EKBOM (1981). \\
\hline \multicolumn{4}{|l|}{ Diptera } \\
\hline Thomasiniana theobaldi Barnes & raspberry & U.S.S.R. & BolDYREV $(1968 b)$ \\
\hline Dasineura tetensi (Rübsaamen) & black currant & U.S.S.R. & $\begin{array}{l}\text { GoNCHAROVA (1968), GonCHAROVA \& } \\
\text { SAMOSUDOV (1979). }\end{array}$ \\
\hline Dasineura mali (Kieffer) & apple & Germany & CARL (1980). \\
\hline Macrolabis sp. & apple & Germany & CARL $(1980)$ \\
\hline Oscinella frit (L.) & cats & England & JONES (1969). \\
\hline \multicolumn{4}{|l|}{ Coleoptera } \\
\hline Coccinella septempunctata $\mathrm{L}$. & $\begin{array}{l}\text { hibernating site } \\
\text { various plants }\end{array}$ & $\begin{array}{l}\text { U.S.S.R. } \\
\text { U.S.S.R. }\end{array}$ & $\begin{array}{l}\text { LIPA \& SEM'YANOV (1967). } \\
\text { SEM'YANOV (1981). }\end{array}$ \\
\hline Coccinella quinquepunctata $\mathrm{L}$. & hibernating site & U.S.S.R. & LiPA \& SEM'YANOV (1967). \\
\hline Adalia bipunctata $(\mathrm{L.})$ & hibernating site & U.S.S.R. & LIPA \& SEM'YANOV (1967). \\
\hline Coccinellids & various plants & Bulgaria & GRIGOROV (1983). \\
\hline Byturus tomentosus (DeGeer) & raspberry & U.S.S.R. & BATASHEVA (1979). \\
\hline Gastrophysa viridula (DeGeer) & Rumex & England & SMITH \& WHITTAKER (1980). \\
\hline \multicolumn{4}{|l|}{ Lepidoptera } \\
\hline Orthotaenia undulana (Denis \& Schiff.) & raspberry & U.S.S.R. & BATASHEVA (1981). \\
\hline Choristoneura diversana (Hübner) & raspberry & U.S.S.R. & BATASHEVA (1981). \\
\hline Archips rosanus (L.) & raspberry & U.S.S.R. & BATASHEVA (1981). \\
\hline Archips xylosteanus (L.) & raspberry & U.S.S.R. & BATASHEVA (1981). \\
\hline Archips podanus (Scopoli) & raspberry & U.S.S.R. & BATASHEVA (1981). \\
\hline Ptycholoma lecheanum (L.) & raspberry & U.S.S.R. & BATASHEVA (1981). \\
\hline Pandemis cerasana (Hübner) & raspberry & U.S.S.R. & BATASHEVA (1981). \\
\hline Hedya nubiferana (Haworth) & raspberry & U.S.S.R. & BATASHEVA (1981). \\
\hline Syndemis musculana (Hübner) & raspberry & U.S.S.R. & BATASHEVA (1981). \\
\hline Eulia ministrans (L.) & raspberry & U.S.S.R. & BATASHEVA (1981). \\
\hline Cnephasia sp. & raspberry & U.S.S.R. & BATASHEVA (1981). \\
\hline Cydia funebrana (Treitschke) & plum & U.S.S.R. & GOLUBENKo (1969). \\
\hline Cydia pomonella $(\mathrm{L})$. & apple & England & GLEN (1975). \\
\hline Phyllonorycter pyrifoliella (Gerasimov) & apple & U.S.S.R. & BOLDHYREV $(1968 a, 1975)$. \\
\hline Sitotroga cerealella (Olivier) & laboratory & Poland & NiEMCZYK (1970). \\
\hline \multicolumn{4}{|l|}{ Mites } \\
\hline \multirow[t]{6}{*}{ Panonychus ulmi (Koch) } & apple & U.S.S.R. & SidLYAREVICH (1965). \\
\hline & & Poland & KoRCZ (1971). \\
\hline & & Bulgaria & KARADZHOV $(1973 a, 1973 b)$. \\
\hline & & France & FAUVEL $(1974 a)$ \\
\hline & & England & SOLOMON (1982). \\
\hline & orchards & U.S.S.R. & SidlyareVich (1968). \\
\hline Bryobia rubrioculus (Scheuten) & apple & Poland & KorCZ (1971). \\
\hline Tetranychus urticae Koch & apple & Poland & KORCZ (1971). \\
\hline Tetranychus viennensis Zacher & apple & Poland & KORCZ (1971). \\
\hline Tetranychids spp. & various plants & Bulgaria & BALEVSKI (1977). \\
\hline \multicolumn{4}{|l|}{ Various prey } \\
\hline & apple & East Germany & ZELETZKI \& RINNHOFER (1966). \\
\hline & & Poland & KorCZ (1967), NiEMCZYK $(1969,1978 b)$. \\
\hline & & Sweden & NORDLANDER (1977). \\
\hline & & Norway & $\begin{array}{l}\text { AUSTRENG \& SOMME (1980), SKANLAND } \\
\text { (1981). }\end{array}$ \\
\hline & various plants & Yugoslavia & GOLLNER-SCHEIDING (1978). \\
\hline & & Germany & LAUENSTEIN $(1977,1980)$ \\
\hline
\end{tabular}


$P$. pyri in southeastern France (ATGER, 1979b). It generally shows a degree of specificity for a prey in a particular habitat, for example in apple orchards, for Panonychus ulmi (Koch) (FAUVEL, 1974a), Thrips major Uzel, and Thrips flavus Schrank (FAUVEL et al., 1980) and in pear orchards, for P. ulmi (FAUVEL \& ATGER, 1981). It prefers the phytophagous mite, Aceria fraxinivora (Nal.), and the predacious cecidomyiid, Arthrocnodax fraxinella (Meade), in ash spangle galls (FAUVEL et al., 1978), Coryihucha ciliata (Say) on plane trees (D'AgulLAR et al., 1977), Aphis gossypii Glover, Thrips tabaci Lindemann, and spider mites on cucurbitaceous crops and egg plant (AKRAMOVSKAYA, 1978). In some cases, $O$. vicinus was noted as a pollen feeder (FAUVEL, 1974b). The distribution of $O$. vicinus is not completely known ; it seems widely distributed in Europe south of the 60th parallel, and we have very little information on its distribution in Asia (PERICART, 1972). It has been noted recently from China (ZHENG, 1982).

We observed $O$. minutus associated with pear and hawthorn psyllids in the south of France and in the Paris region (table 2). $O$. minutus has already been reported several times as a predator of eggs and larvae of pear psylla (table 1). Apparently it is a very polyphagous predator, encountered on many species of plants in Europe, Siberia, Turkestan and China; it seems rare in the mediterranean region, but it has been noted from North Africa (PERICART, 1972). Its prey, besides pear psylla, as listed in recent literature are listed in table 7 .

We collected $O$. niger on pear trees, where it attacks eggs and larvae of $P$. pyri, but overall it was most common on nettle infested with $T$. urticae

TABLE 7

Prey of Orius minutus (L.) (other than pear psylla) noted in recent literature.

Proies d'O. minutus (sauf les psylles du poirier) signalées récemment dans la littérature.

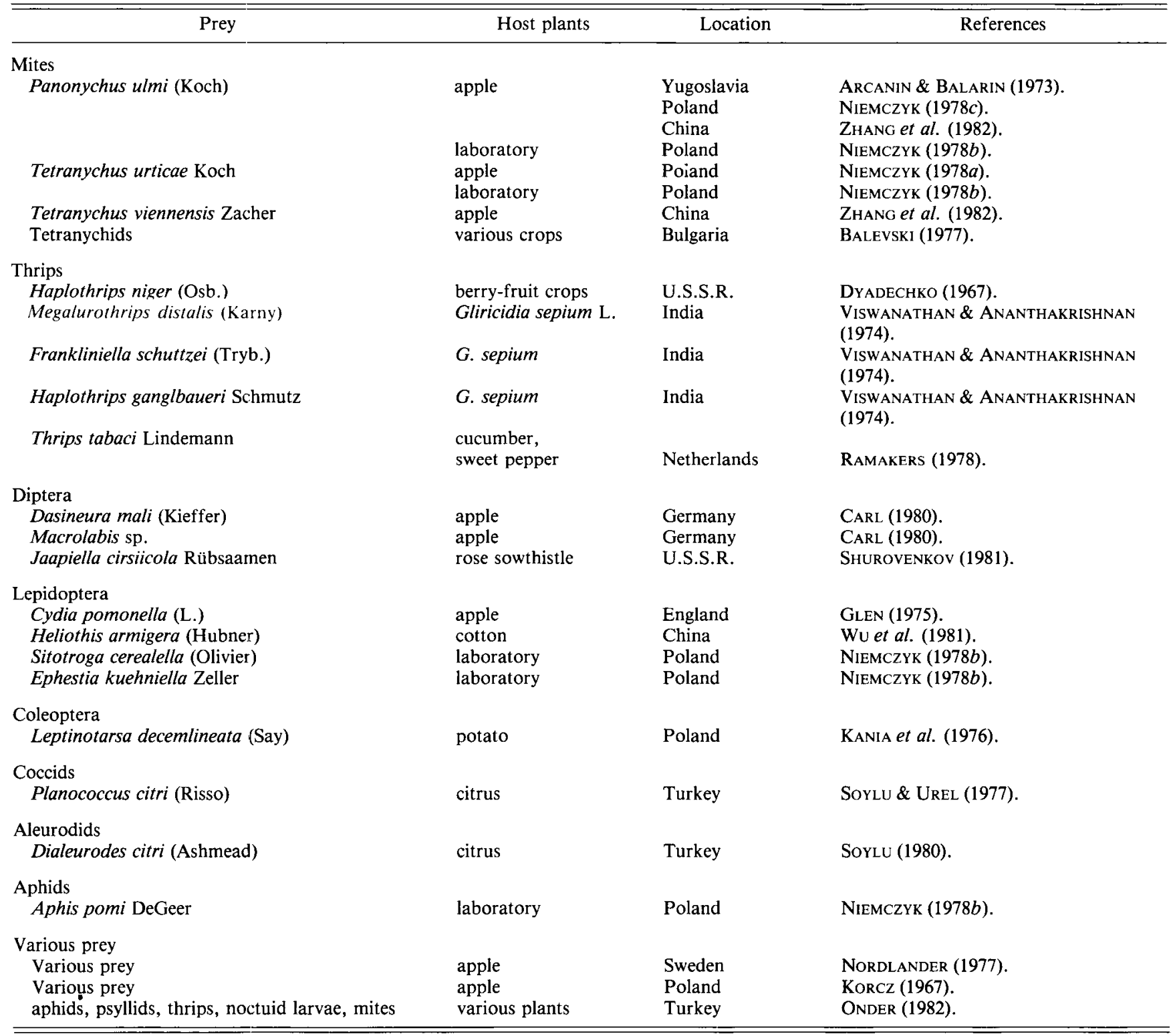


surrounding the orchards (table 2). It had been noted once previously, associated with $P$. pyri (NGUYEN et al., 1981). It is distributed over most of the western palearctic region (PERICART, 1972), and it has been also noted from China (ZHENG, 1982). Its prey, besides $P$. pyri, noted in recent literature, are listed in table 8 .

We found $O$. laevigatus in small numbers in pear orchards of southern France and in the Paris region, as well (table 2). According to PERICART (1972), this Orius is characteristic of the western palearctic region under seaboard influence ; it is common in the mediterranean basin. It was observed on many host plants, mostly shrubs and herbaceous plants (PERICART, 1972). It has been collected several times in Egypt, where it is abundant and widespread (TAWFIK \& ATA, 1974). It was observed there, as a predator of various insect species in fields of clover and cotton (HAFEZ et al., 1975), mainly as a predator of $A$. gossypii and T. tabaci (AFIFI et al., 1980). It also belongs to fauna of apple trees in Egypt, essentially as a predator of Tetranychus turkestani (Ugar. \& Nik.) (ABDELSALAM, 1967).

We rarely encountered $O$. majusculus in orchards attacked by $P$. pyri in Avignon and in the Paris region, although this species is mentioned by PERICART (1972) as common and ubiquitous in France. $O$. majusculus is known to feed on many species of trees and herbaceous plants, mainly consuming aphids and mites (PERICART, 1972). It was recently noted as a predator of the aphids, Diuraphis noxia (Mordvilko) and Schizaphis graminum (Rondani), in barley and wheat in the USSR (BEREST, 1980a). It was already known as a predator of Trialeurodes vaporariorum (Westwood) on greenhouse crops in Italy (ARZONE, 1976) and as a predator of various prey in apple orchards in Poland (KoRCZ, 1967) and of P. ulmi and Tetranychus sp. in apple orchards in France (FAUVEL, 1974a).

Although these species of Orius showed some food preferences in particular habitats, they were essentially polyphagous. They were from the same geographical region, but we observed some differences in their distribution, namely in $O$. minutus, which was more northerly than $O$. vicinus.

Temnostethus pusillus (Herrich-Schaeffer) was very rare in our samples of pear tree fauna (table 2). Although it is known to feed on aphids, psyllids and coccids, its occurrence in fruit trees seems to be related to the presence of lichens; it is known all over Europe and in western USSR (PERICART, 1972).

The presence of Cardiastethus fasciiventris (Garbiglietti) in our samples probably was not exclusively related to the presence of $P$. pyri. In fact, this predator seems mainly to live at the expense of psocids (PERICART, 1972). Psocids feeding on fumagine were numerous on pear trees examined. The known distribution of $C$. fasciiventris is throughout western Europe and North Africa; it has also been observed in Egypt (PERICART, 1972).

TABLE 8

Prey of Orius niger (Wolff) (other than pear psylla), noted in recent literature.

Proies d'O. niger (sauf les psylles du poirier), signalées récemment dans la littérature.

\begin{tabular}{|c|c|c|c|}
\hline Prey & Host plants & Location & References \\
\hline \multicolumn{4}{|l|}{ Aphids } \\
\hline Aphis gossypii Glover & cotton & U.S.S.R. & $\begin{array}{l}\text { AKRAMOVSKAYA (1978), } \\
\text { SUKHORUCHENKO et al. (1981). }\end{array}$ \\
\hline Schizaphis graminum (Rondani) & wheat & U.S.S.R. & BEREST $(1980 b)$ \\
\hline Diuraphis noxia (Mordvilko) & & U.S.S.R. & MYRZIN \& LUK'YANCHIKOV (1981). \\
\hline Sitobion avenae (F.) & Wheat & U.S.S.R. & BEREST (19800). \\
\hline Acyrthosiphon gossypii Mordvilko & & & BEREST $(1980 b)$ \\
\hline \multirow{2}{*}{\multicolumn{4}{|c|}{ Thrips }} \\
\hline & & & \\
\hline Thrips tabaci Lindemann & cucurbits, eggplant & U.S.S.R. & AKRAMOVSKAYA (1978). \\
\hline T. tabaci & tobacco & Bulgaria & Dimitrov (1975). \\
\hline Thrips spp. & berry-fruit crops & U.S.S.R. & DYADEChKO (1967). \\
\hline \multicolumn{4}{|l|}{ Aleurodids } \\
\hline Trialeurodes vaporariorum (Westwood) & greenhouse crops & Italy & ARZONE (1976). \\
\hline \multicolumn{4}{|l|}{ Diptera } \\
\hline Jaapiella cirsiicola Rübsaamen & rose sowthistle & U.S.S.R. & SHUROVENKOV (1981). \\
\hline \multicolumn{4}{|l|}{ Lepidoptera } \\
\hline Heliothis armigera (Hübner) & cotton & U.S.S.R. & SUKHORUCHENKO et al. (1981). \\
\hline \multicolumn{4}{|l|}{ Mites } \\
\hline Panonychus ulmi (Koch) & apple & Yugoslavia & ARCANIN \& BALARIN (1973). \\
\hline Tetranychus urticae Koch & cotton & U.S.S.R. & SUKHORUCHENKO et al. (1981). \\
\hline mites & cucurbits, eggplant & U.S.S.R. & AKRAMOVSKAYA (1978). \\
\hline \multicolumn{4}{|l|}{ Various prey } \\
\hline aphids, psyllids, thrips, noctuid larvae, mites & various plants & Turkey & ONDER (1982). \\
\hline
\end{tabular}




\section{b) Miridae}

Heterotoma meriopterum (Scopoli) was not only one of the most common mirids in the pear orchards we visited but also on hawthorn and nettle, where it feeds mainly on psyllids and aphids. It has one generation per year, the egg overwintering (FAUVEL, $1974 a$ ). On pear trees, eggs are laid in young twigs. We cut these twigs in autumn, obtained many individuals and placed them in a refrigerator. Normal and unavoidable pruning of pear trees in winter intensely depressed predator populations in the orchard. Consequently, plants such as hawthorn were very useful for survival of this pear psylla enemy and to retain them near the orchards. Its abundance in orchards is not constant since FAUVEL \& ATGER (1981) found it in low numbers. It has also been noted as a predator of aphids and of the mite, Bryobia rubrioculus (Scheuten), on apple (FAUVEL, 1974a). It sometimes feeds on plant sap (WAGNER \& WEBER, 1964 ; FaUvel \& GrivaUt, 1976). It is widely distributed in Europe and North Africa (WAGNER \& WEBER, 1964).

Campyloneura virgula (Herrich-Schaeffer) was the second most common mirid found in our samples from pear orchards, being as abundant in southern France as in the Paris region, where it also occurred on hawthorn (table 2). This polyphagous predator, already observed on various deciduous trees, Fraxinus, Tilia, Alnus, Fagus (WAGNER \& WEBER, 1964), has not been reported in orchards before. It is a poorly known species. We verified that it is exclusively represented by females; its reproduction very probably is parthenogenetic (WAGNER \& WEBER, 1964). It is distributed throughout Europe, North Africa and the Near East (WAGNER \& WEBER, 1964).

Orthotylus nassatus (F.) was the third most abundant mirid collected in pear orchards in southern France (table 2). It is a polyphagous predator encountered notably on Quercus, Tilia, Fraxinus and Salix and known throughout Europe (WAGNER \& WEBER, 1964). It has already been noted on pear (FAUVEl \& ATGER, 1981) but seems more tied to locuses of infestation of the mite $P$. ulmi than of pear psylla. O. nassatus was fortuitously, and successfully, introduced in North America, probably in nursery stock. It has been found in Pennsylvania on pear (HENRY, 1977) and on maple (HENRY \& WHEELER, 1979). It has been found in Canada on maple, walnut, and lime infested with aphids and on pear infested with $P$. pyricola (KELTON, 1982).

All other mirids cited below were rare in pear orchards examined.

Deraeocoris lutescens (Schilling) has already been reported as a predator associated with pear psylla (table 2), mainly as a predator of its eggs (FAUVEL \& ATGER, 1981), of aphids on lime and oak (WAGNER \& WEBER, 1964), and above all as a predator of $P$. ulmi in apple orchards (ARCANIN \& BALARIN, 1973) and in pear orchards (FAUVEL \& ATGER, 1981). D. lutescens is a mediterranean species also found in central Europe (WAGNeR \& WeBER, 1964) and in Poland (NIEMCZYK et al., 1972).

Deraeocoris ruber (L.) has been known as an occasional predator of $P$. pyri in Italy (table 1), of aphids, young caterpillars, mites, and various small insects on apple (FAUVEL, 1974a), on Rubus and Urtica (WAGNER \& WEBER, 1964) and on Corylus (VIGGIANI, 1971). The most commonly observed aphids, which served as prey on hazel in Italy, were Myzocallis coryli (Goeze) and Corylobium avellanae (Schrank) (VIGGIANI, 1971). It is distributed everywhere in Europe, but is more common in the south. It was recorded for the first time in the US on egg plant at Newark, New Jersey, in 1979 (USDA, 1980).

Pilophorus perplexus (Douglas \& Scott) has already been noted as a predator of $P$. pyri in France (FAUVEL \& ATGER, 1981), though not very abundant in orchards. In apple orchards it has been also known as a predator of $A$. pomi and $B$. rubrioculus in France (FAUVEL, 1974a) and of $P$. ulmi in Russia (SidlyareVich, 1968) and in Canada (LoRD, 1968, 1971). P. perplexus has been found on various other deciduous trees, Fraxinus, Alnus, Tilia, Acer, Quercus, and Salix (WAGNER \& WEBER, 1964).

Pilophorus gallicus Remane was very rare in our samples of predators collected on pear trees near Avignon. Formerly, it was only known on Populus and Salix in southern France (WAGNER \& WEBER, 1964).

Pilophorus clavatus (L.) was rare on pear trees near Toulouse. It has been recorded from Salix, Tilia, Quercus and Populus in Europe and North America (WAGNER \& WEBER, 1964).

Mimocoris rugicollis (Costa) was also very rare on pear trees in Avignon. This mediterranean species has already been observed on Quercus ilex (WAGNER \& WEBER, 1964).

We observed Psallus ambiguus (Fallen) in low numbers on pear and hawthorn (table 2). According to WAGNER \& WEBER (1964), this polyphagous predator, which is occasionally phytophagous, is known throughout Europe. It has been observed on Pirus, Alnus and Salix and especially on apple in France (FAUVEL, 1974a), in England (MORRIS, 1968), in Yugoslavia (ARCANIN \& BALARIN, 1973), in Poland (KoRCZ, 1967 ; NIEMCZYK, 1967, 1968) and in Norway (Austreng \& Somme, 1980 ; Skanland, 1981). Its most common prey are $P$. ulmi, Bryobia spp., Psylla mali Schmidberger, A. pomi, and Brachycaudus helichrysi (Kaltenbach) (NIEMCZYK, 1968).

We encountered some specimens of Phytocoris longipennis Flor in pear orchards at Toulouse and in the Paris region (table 2). This predator has already been recorded feeding on small insects in apple orchards (FAUVEL, 1974a) and on Acer, Corylus, Quercus and Fagus (WAGNER \& WEBER, 1964). According to these authors, it is distributed throughout Europe but is more common in northern and central Europe. It was noted recently in Turkey (ERKIN, 1983).

Phytocoris ulmi (L.) was found in very low numbers in the pear orchard visited at Toulouse. It had previously been noted in France on apple (FAUVEL, 1974a) and as a possible vector of fireblight on the shoots of pear in Denmark (THYGESEN et al., 1973). Moreover, it is known on Ulmus, Acer, Prunus, Fagus, Corylus, Salix and Cistus (WAGNER \& WEBER, 1964). These authors indicated that its 
distribution is throughout Europe, North Africa, Asia Minor and Caucasia.

\section{c) Nabidae}

Nabid predators were very rare in the examined orchards and were represented by only 3 species (table 2). Himacerus apterus (L.) has previously been noted on apple in Poland (KoRCZ, 1967) and in France (FAUVEL, 1974a), but has been encountered most frequently on herbaceous plants and bushes as a predator of aphids and young caterpillars. It occurs throughout Europe (FAUVEL, 1974a). It has also been noted as a predator of aphids in pine plantations grown for seed in Russia (SMETANIN, 1970).

Nabis ferus (L.) has been noted in apple orchards in France (FAUVEL, 1974a) and the USA (WHALON \& PARKER, 1978), but it mainly occurs in grass and bushes. The list of its main prey is presented in table 9 .

Nabis punctatus Costa was previously observed on apple in France (FAUVEL, 1974a) and in the USSR as a predator of aphids on various plants (PUCHKOV, 1980) and as one of the main predators of cereal aphids, D. noxia, S. graminum and Sitobion avenae (F.) (BEREST, 1980b).

\section{Coleoptera}

\section{a) Coccinellidae}

Small ladybird beetles of the Scymnini tribe were represented in our samples by 4 species, 3 of which, Stethorus punctillum (Weise), Scymnus rubromaculatus (Goeze) and Scymnus subvillosus (Goeze), were abundant on pear trees at Avignon (table 2). According to IPERTI (1974), Gourreau (1974), FAUVEL \& ATGER (1981), S. punctillum shows a degree of specificity for fruit tree mites, notably for $P$. ulmi and Tetranychus urticae Koch. It probably is an occasional predator of pear psylla. Its main prey are listed in table 10.

The coccinellid, S. rubromaculatus, very common in France and in the major part of the palearctic region, has been known as a predator of aphids on oak, willow, hazel, peach, juniper, box and various cereals, mainly maize (Gourreau, 1974). Since aphids did not proliferate in the orchard visited at Avignon, presence of this predator is most probably related only to pear psylla.

Previously, S. subvillosus had been often observed on various fruit trees, orange, peach, plum (GouR REAU, 1974) and apple (IPERTI, 1974), and on many other host plants, oak, juniper, hazel, laurel, tamarisk, pine, maize (GOURREAU, 1974). S. subvillosus has generally been noted as a predator of aphids, of Brevicoryne brassicae (L.) on cultivated crucifers in Rumania (CONSTANTINESCU, 1972), cereal aphids on wheat, oats and barley in the USSR (ABDULKHAIROVA, 1979), Aphis craccivora Koch on liquorice in the USSR (KESTEN, 1975), Brachycaudus amygdalinus (Schouteden) and B. helichrysi on almond, and of some coccids, Planococcus citri (Risso) on grape vine, citrus and pomegranate in the USSR, and Saissetia oleae (Olivier) on olive in Greece (ARGYRIOU \& KATSOYANNOS, 1977).

Scymnus interruptus (Goeze) was very rare on pear trees attacked by $P$. pyri at Avignon, probably due to its high preference for aphids. In fact, TAWFIK et al. $(1974 a)$ found that its development and reproduction are possible only when aphids are available as prey.

$S$. interruptus is known in the major part of the palearctic region from many plants (GoURREAU, 1974), but it is especially efficacious against $A$. gossypii on cotton in Egypt (HASSANEIN et al., 1968 ; REZK et al., 1975 ; НАВІB et al., 1980). In Egypt, $S$. interruptus was also found preying on Aphis nerii

TABLE 9

Prey of Nabis ferus (L.), noted in recent literature.

Proies de $\mathrm{N}$. ferus, signalées récemment dans la littérature.

\begin{tabular}{|c|c|c|c|}
\hline Prey & Host plants & Location & References \\
\hline \multicolumn{4}{|l|}{ Mirids } \\
\hline $\begin{array}{l}\text { Lygus lineolaris (Palisot de Beauvois) } \\
\text { Lygus rugulipennis Poppius }\end{array}$ & $\begin{array}{l}\text { apple } \\
\text { strawberry }\end{array}$ & $\begin{array}{l}\text { U.S.A. } \\
\text { Sweden }\end{array}$ & $\begin{array}{l}\text { WHALON \& PARKER (1978). } \\
\text { GERTSSON (1980). }\end{array}$ \\
\hline Aphids & $\begin{array}{l}\text { various plants } \\
\text { pine }\end{array}$ & $\begin{array}{l}\text { U.S.S.R. } \\
\text { U.S.S.R. }\end{array}$ & $\begin{array}{l}\text { Puchkov (1980). } \\
\text { Smetanin (1970). }\end{array}$ \\
\hline \multicolumn{4}{|l|}{ Lepidoptera } \\
\hline $\begin{array}{l}\text { Pectinophora gossypiella (Saunders) } \\
\text { Heliothis zea (Boddie) }\end{array}$ & $\begin{array}{l}\text { cotton } \\
\text { cotton }\end{array}$ & $\begin{array}{l}\text { Mexico } \\
\text { Mexico }\end{array}$ & $\begin{array}{l}\text { Estrada \& CARrillo (1971). } \\
\text { Estrada \& CARRILlo (1971). }\end{array}$ \\
\hline \multicolumn{4}{|l|}{ Coleoptera } \\
\hline Leptinotarsa decemlineata (Say) & potato & Poland & ZIARKIEWICZ (1976). \\
\hline \multicolumn{4}{|l|}{ Diptera } \\
\hline Jaapiella cirsiicola Rübsaamen & rose sowthistle & U.S.S.R. & SHUROVENKOV (1981). \\
\hline \multicolumn{4}{|l|}{ Thrips } \\
\hline Thrips tabaci Lindemann & tobacco & Bulgaria & Dimitrov (1975). \\
\hline
\end{tabular}




\section{TABLE 10}

Prey of Stethorus punctillum (Weise) (other than pear psylla), noted in recent literature.

Proies de S. punctillum (sauf les psylles du poirier), signalées récemment dans la littérature.

\begin{tabular}{|c|c|c|c|}
\hline Prey & Host plants & Location & References \\
\hline \multicolumn{4}{|l|}{ Mites } \\
\hline \multirow[t]{2}{*}{ Panonychus ulmi (Koch) } & apple & $\begin{array}{l}\text { France } \\
\text { Italy }\end{array}$ & $\begin{array}{l}\text { Audemard (1973). } \\
\text { Pasqualini (1979), Papaioannou- } \\
\text { Soulioti (1980), Mori \& Vianelo } \\
\text { (1980), PasQualini } \text { et al. (1982). } \\
\text { VereshCHAGiNa (1981). }\end{array}$ \\
\hline & strawberry & Italy & PaPaloannou-SOULIOTI (1980). \\
\hline \multirow{3}{*}{$\begin{array}{l}\text { Panonychus citri (McGeer) } \\
\text { Eotetranychus pruni (Oudm.) }\end{array}$} & citrus & Spain & GARCIA MARI \& RIV̀ERO (1982). \\
\hline & grapevine & Bulgaria & BAYAN (1981). \\
\hline & various orchards & U.S.S.R. & KARTASHEVA \& LESTEVA (1979). \\
\hline \multirow{4}{*}{$\begin{array}{l}\text { Eotetranychus carpini vitis (Boisd.) } \\
\text { Tetranychid \& Eriophyid mites } \\
\text { various mites }\end{array}$} & grapevine & Italy & LAFFI (1982). \\
\hline & various plants & Bulgaria & BALEVSKI (1977). \\
\hline & apple & France & IPERTI (1974). \\
\hline & various orchards & U.S.S.R. & LiVSHITS \& MitRofaNOV $(1981 b)$ \\
\hline \multicolumn{4}{|l|}{ Aphids } \\
\hline Aphis craccivora Koch & liquorice & U.S.S.R. & KESTEN (1975). \\
\hline \multicolumn{4}{|l|}{ Coccids } \\
\hline Saissetia oleae Olivier & olive & Greece & Argyriou \& Katsoyannos (1977). \\
\hline \multirow{2}{*}{$\begin{array}{l}\text { Various prey } \\
\text { mites, aphids }\end{array}$} & & & \\
\hline & $\begin{array}{l}\text { lime, citrus, apple, } \\
\text { hazel, plum, peach, } \\
\text { oak, pine, cypress, } \\
\text { raspberry, ivy, maize, } \\
\text { Pittosporum, tobacco, } \\
\text { rose, moss. }\end{array}$ & $\begin{array}{l}\text { Paleartic } \\
\text { region }\end{array}$ & Gourreau (1974). \\
\hline
\end{tabular}

Boyer on Nerium oleander L., on Aphis verbasci Schrank on Buddleia asiatica Lour., on Aphis punicae Passerini on Duranta sp. and on Rhopalosiphum maidis (Fitch) on maize (TAWFIK et al., 1974b). It can feed on nectar and secretions from the leaves. CONSTANTINESCU (1972) observed $S$. interruptus as a predator of $B$. brassicae on cultivated crucifers in Rumania.

Rhyzobius chrysomeloides (Herbst) was also rare in our samples and we did not find it noted as a predator of any pest of economic importance in the literature.

Clitostethus arcuatus (Rossi) was collected on hawthorn, but its presence was probably tied more to the presence of aleurodids than to psyllids on this host plant. C. arcuatus has been noted as the main natural enemy of Dialeurodes citri (Ashmead) on citrus in Italy (PRIORE, 1969 ; LiOTTA \& MANIGLiA, 1975 ; LOI, 1979 ; DELRIO et al., 1981 ; LIOTTA, 1981), in Turkey (SOYLU, 1980), and in the USSR (AGEKYAN, 1977). It has also been observed as a predator of Aleurothrixus floccosus (Mask.) (Aleurodidae) on Citrus in Italy (LIOTTA, 1982) and in Portugal (MagalhaEs, 1980). On apple and pear, C. arcuatus has been noted as a predator of the aleurodid, Siphoninus phillyreae (Haliday), in Greece (MENTZElos, 1967) and in Italy (TREMblay, 1969). $C$. arcuatus has been found preying on $T$. vaporariorum on tobacco in the USSR (AGEKYAN, 1977). However, it seemed to be capable of attacking prey other than aleurodids; it has been noted in wooded areas and occasionally was observed preying on aphids (AGEKYAN, 1977).
We observed Adalia bipunctata (L.) in low numbers in all pear orchards infested with pear psylla (table 2). This coccinellid was already noted as an enemy of $P$. pyri in Poland and in the USSR (table 1). However, its main prey are aphids of trees of the family of Rosaceae (IPERTI, 1978a, b). Its main prey from recent literature are listed in table 11. A. bipunctata has been reared and released in pear orchards for control of $P$. pyricola in central Washington (USA) without apparent establishment (FYE, 1981).

Synharmonia conglobata (L.) was very rare in pear orchards examined (table 2). This coccinellid has already been collected in Israel as a predator of $P$. pyricola (SWIRSKI, 1954). Its main prey were aphids (table 12). It has been reared and released against $P$. pyricola in central Washington (USA), without apparent establishment (FYE, 1981).

Synharmonia lyncea Olivier was found in very small numbers on pear trees at Toulouse (table 2). This coccinellid generally was rare in the field. It has been collected on oak and lime infested with aphids in East Germany (WITSACK, 1971). According to this author it accepts Aphis fabae Scopoli and Myzus persicae (Sulzer) as prey in the laboratory. Its known prey in the field are Dysaphis sorbi (Kaltenbach) and Eucallipterus tiliae (L.) (WITSACK, 1971).

Propylea quattuordecimpunctata (L.) was present in very small numbers in pear orchards at Avignon and Toulouse. It is essentially a predator of aphids (table 13). It has been reared and released in pear orchards in central Washington (USA) without apparent establishment (FYE, 1981). 
TABLE 11

Prey of Adalia bipunctata (L.) (other than pear psylla), noted in recent literature.

Proies d'A. bipunctata (sauf les psylles du poirier), signalées récemment dans la littérature.

\begin{tabular}{|c|c|c|c|}
\hline Prey & Host plants & Location & References \\
\hline \multicolumn{4}{|l|}{ Aphids } \\
\hline \multirow[t]{2}{*}{ Microlophium carnosum (Buckton) } & $\begin{array}{l}\text { oats, wheat, barley, } \\
\text { rye, maize }\end{array}$ & Argentina & $\begin{array}{l}\text { SERANTES dE GonZaLEZ \& SierRa de } \\
\text { NunEZ (1976). }\end{array}$ \\
\hline & Urtica dioica $\mathrm{L}$ & Czechoslovakia & HONEK (1978). \\
\hline Macrosiphoniella artemisiae (Boyer) & Artemisia vulgaris L. & Czechoslovakia & HONEK (1978). \\
\hline Myzus cerasi $(\mathrm{F})$. & cherry & France & IPERTI $(1978 a)$ \\
\hline \multirow[t]{2}{*}{ Aphis fabae Scopoli } & sugar beet & England & НEATHCOTE (1978). \\
\hline & $\begin{array}{l}\text { Euonymus alatus } \\
\text { (Thunb.) }\end{array}$ & U.S.A. & WHEELER \& STIMMEL (1979). \\
\hline Eucallipterus tiliae (L.) & lime & England & DiXON \& BARLOW (1979), Mills (1982). \\
\hline Brevicoryne brassicae (L.) & cabbage & U.S.S.R. & YASTREBOV (1979). \\
\hline \multirow[t]{2}{*}{ Metopolophium dirhodum (Walker) } & wheat, Bromus unio- & & \\
\hline & loides (Willd.) & Argentina & Botтo et al. (1979). \\
\hline \multirow{6}{*}{$\begin{array}{l}\text { Lachnus roboris (L.) } \\
\text { Rhopalosiphum padi (L.) } \\
\text { aphids }\end{array}$} & Quercus robur L. & U.S.S.R. & BLAZHIEVSKAYA (1980). \\
\hline & Prunus padus L. & West Germany & BODE $(1980 a)$ \\
\hline & apple & France & IPERTI (1974). \\
\hline & cereals & U.S.S.R. & ABdulKhairova (1979). \\
\hline & $\begin{array}{l}\text { wheat } \\
\text { pome \& stone fruit }\end{array}$ & England & DEAN (1982). \\
\hline & trees & Turkey & ERKIN (1983). \\
\hline \multicolumn{4}{|l|}{ Coleoptera } \\
\hline Chrysomela populi L. & poplar & Romania & TEODORESCU $(1980)$ \\
\hline Chrysomela saliceti (Weise) & poplar & Romania & TEODORESCU $(1980)$. \\
\hline Chrysomela tremula $\mathrm{F}$ & poplar & Romania & TEODORESCU $(1980)$. \\
\hline \multicolumn{4}{|l|}{ Lepidoptera } \\
\hline Colias lesbia $(\mathrm{F})$. & lucerne & Argentina & BotTo \& CRouzel (1981). \\
\hline \multicolumn{4}{|l|}{ Coccids } \\
\hline Pseudaulacaspis pentagona (Targioni-Tozzetti) & Kwanzan cherry & U.S.A. & STIMMEL (1982). \\
\hline \multirow[t]{3}{*}{ Various prey } & apple & $\begin{array}{l}\text { Sweden } \\
\text { Hungary }\end{array}$ & NORDLANDER (1977). \\
\hline & orchards & U.S.S.R. & LiVSHITZ \& MiTROFANOV $(1981 b)$. \\
\hline & various trees & England & MiLls (1979). \\
\hline
\end{tabular}

Among the species of large coccinellids, Coccinella septempunctata $\mathrm{L}$. was the most abundant on pear trees examined at Avignon and Toulouse (table 2). It has already been noted as a predator of $P$. pyri in Europe (table 1) and of $P$. pyricola in Israel (SWIRSKI, 1954). It has been reared and released against $P$. pyricola in central Washington (USA); it survived the mild winter there but without lasting establishment in pear orchards (FYE, 1981). C. septempunctata is a very polyphagous predator ; its main prey are listed in table 14.

We collected some specimens of Chilocorus renipustulatus (Scriba) on pear trees at Toulouse (table 2). This coccinellid has been recognized as a predator of coccids, but it has also been noted as a predator of mites. C. renipustulatus is considered in the USSR to be one of the main predators of the coccid, Quadraspidiotus perniciosus (Comstock), on fruit trees (PANTYUKHov, 1968 ; MURASHEVSKAYA, 1969 ; PoPova, 1971, 1974). In Bulgaria, TSACHEV (1978) observed it on apple and willow as a predator of Lepidosaphes ulmi (L.). In France, BAYLAC (1980) observed it as a predator of Cryptococcus fagi (Baerensprung) on beech, and IPERTI (1974) as a predator of various coccids on apple. GoKSU \& ATAK (1969) observed $C$. renipustulatus as a predator of the mite $P$. ulmi on a wide variety of fruit trees and also vines and hazel in Turkey.

We found Coccinula quatuordecimpustulata (L.) in very low numbers on pear trees at Toulouse (table 2). This coccinellid has been recorded in the literature most often as a predator of aphids. In the USSR, it attacks $A$. pisum on leguminous crops (KANTERINA, 1974) and various aphids on cereal crops and alfalfa (Fedosimov \& TSEDEV, 1970). It was observed as a predator of aphids in Poland on alfalfa (PRUSZYNSKI \& LIPA, 1971) and on potato (KACZMAREK, 1973), and in Bulgaria on herbaceous crops (GRIGOROV, 1977a).

Some specimens of Thea vigintiduopunctata (L.) were collected on pear trees at Avignon (table 2). This coccinellid has already been noted several times in orchards, as a predator of coccids in Turkey (ALTAY et al., 1973) and in Iran on apple trees infested with Lepidosaphes malicola Borkhs. (MOSTAAN et al., 1972). T. vigintiduopunctata also was noted as predator of the two-spotted spider mite T. urticae on bean (Phaseolus) in Turkey (ONGOREN et al., 1975). It was noted in the USSR as a predator of cereal aphids on wheat, oats and barley (ABDULKHAIROVA, 1979), as a predator of $S$. graminum on rice (MYRZIN \& LUK'YANCHIKOV, 1981) and of $A$. pisum on alfalfa 
TABLE 12

Prey of Synharmonia conglobata (L.) (other than pear psylla), noted in recent literature.

Proies de S. conglobata (sauf les psylles du poirier), signalées récemment dans la littérature.

\begin{tabular}{|c|c|c|c|}
\hline Prey & Host plants & Location & References \\
\hline \multicolumn{4}{|l|}{ Aphids } \\
\hline $\begin{array}{l}\text { Aphis gossypii Glover } \\
\text { Aphis craccivora Koch } \\
\text { Brachycaudus amygdalinus (Schouteden) } \\
\text { Brachycaudus helichrysi (Kaltenbach) } \\
\text { Toxoptera aurantii (Boyer) } \\
\text { Myzus persicae (Sulzer) } \\
\text { aphids }\end{array}$ & $\begin{array}{l}\text { cotton } \\
\text { citrus } \\
\text { liquorice } \\
\text { almond } \\
\text { almond } \\
\text { citrus } \\
\text { citrus } \\
\text { apple } \\
\text { trees, shrubs } \\
\text { wheat, oats, barley } \\
\text { pome \& stone fruit } \\
\text { trees }\end{array}$ & $\begin{array}{l}\text { U.S.S.R. } \\
\text { Greece } \\
\text { U.S.S.R. } \\
\text { Lebanon } \\
\text { Lebanon } \\
\text { Greece } \\
\text { Greece } \\
\text { France } \\
\text { Bulgaria } \\
\text { U.S.S.R. } \\
\text { Turkey }\end{array}$ & $\begin{array}{l}\text { ALEKSEEV \& NiYAZOV (1975). } \\
\text { ARGYRIOU (1970). } \\
\text { KESTEN (1975). } \\
\text { TALHOUK (1977). } \\
\text { TALHOUK (1977). } \\
\text { ARGYRIOU (1970). } \\
\text { ARGYRIOU (1970). } \\
\text { IPERTI (1974). } \\
\text { GRIGOROV (1977a). } \\
\text { ABDULKHAIROVA (1979). } \\
\text { ERKIN (1983). }\end{array}$ \\
\hline \multicolumn{4}{|l|}{ Coccids } \\
\hline $\begin{array}{l}\text { Quadraspidiotus perniciosus (Comstock) } \\
\text { Pseudaulacaspis pentagona (Targioni-Tozzetti) } \\
\text { Parlatoria spp. } \\
\text { Eulecanium prunastri (Fonscolombe) } \\
\text { Parthenolecanium corni (L.) } \\
\text { Ceroplastes sinensis Del G. } \\
\text { Lepidosaphes ulmi (L.) }\end{array}$ & $\begin{array}{l}\text { orchards } \\
\text { orchards } \\
\text { orchards } \\
\text { orchards } \\
\text { orchards } \\
\text { orchards } \\
\text { orchards }\end{array}$ & $\begin{array}{l}\text { Turkey } \\
\text { Turkey } \\
\text { Turkey } \\
\text { Turkey } \\
\text { Turkey } \\
\text { Turkey } \\
\text { Turkey }\end{array}$ & $\begin{array}{l}\text { ALTAY et al. (1973). } \\
\text { ALTAY et al. (1973). } \\
\text { ALTAY et al. (1973). } \\
\text { ALTAY et al. }(1973) . \\
\text { ALTAY et al. }(1973) \text {. } \\
\text { ALTAY et al. }(1973) . \\
\text { ALTAY et al. }(1973) .\end{array}$ \\
\hline \multicolumn{4}{|l|}{ Coleoptera } \\
\hline $\begin{array}{l}\text { Altica quercetorum Foudr. } \\
\text { Altica sp. }\end{array}$ & $\begin{array}{l}\text { oak } \\
\text { Elaeagnus angustifo- } \\
\text { lia (Nakai) }\end{array}$ & $\begin{array}{l}\text { U.S.S.R. } \\
\text { China }\end{array}$ & $\begin{array}{l}\text { Plugaru (1969). } \\
\text { Chen (1982). }\end{array}$ \\
\hline
\end{tabular}

TABLE 13

Prey of Propylea quattuordecimpunctata (L.), noted in recent literafure.

Proies de P. quattuordecimpunctata, signalées récemment dans la littérature.

\begin{tabular}{|c|c|c|c|}
\hline Prey & Host plants & Location & References \\
\hline \multicolumn{4}{|l|}{ Aphids } \\
\hline $\begin{array}{l}\text { Aphis fabae Scopoli } \\
\text { Aphis gossypii Glover } \\
\text { Metopolophium dirhodum (Walker) } \\
\text { Metopolophium festucae (Theobald) } \\
\text { Sitobion avenae (F.) } \\
\text { Rhopalosiphum maidis (Fitch) } \\
\text { Rhopalosiphum padi (L.) } \\
\text { Brachycaudus helichrysi (Kaltenbach) } \\
\text { aphids }\end{array}$ & $\begin{array}{l}\text { sugar-beet } \\
\text { cucumber } \\
\text { wheat } \\
\text { wheat } \\
\text { wheat } \\
\text { maize } \\
\text { Prunus padus } \mathrm{L} \text {. } \\
\text { sunflower } \\
\text { cultivated bushes } \\
\text { wheat, oats, barley } \\
\text { lucerne, clover, cereals }\end{array}$ & $\begin{array}{l}\text { England } \\
\text { U.S.S.R. } \\
\text { U.S.S.R. } \\
\text { England } \\
\text { England } \\
\text { England } \\
\text { France } \\
\text { West Germany } \\
\text { Yugoslavia } \\
\text { France } \\
\text { U.S.S.R. } \\
\text { Czechoslovakia }\end{array}$ & $\begin{array}{l}\text { HEATHCOTE (1978). } \\
\text { GUMOVSKAYA (1982). } \\
\text { YARKULOV (1978). } \\
\text { CHAMBERS et al. (1982). } \\
\text { CHAMBERS et al. (1982). } \\
\text { CHAMBERS et al. (1982). } \\
\text { IPERTI }(1978 a) . \\
\text { BODE }(1980 a) . \\
\text { THALJI (1981). } \\
\text { IPERTI }(1978 b) . \\
\text { ABDULKHAIROVA (1979). } \\
\text { HONEK }(1982) .\end{array}$ \\
\hline \multicolumn{4}{|l|}{ Lepidoptera } \\
\hline $\begin{array}{l}\text { Plutella xylostella (L.) } \\
\text { Artogeia rapae (L.) } \\
\text { Mamestra brassicae (L.) }\end{array}$ & $\begin{array}{l}\text { cabbage } \\
\text { cabbage } \\
\text { cabbage }\end{array}$ & $\begin{array}{l}\text { U.S.S.R. } \\
\text { U.S.S.R. } \\
\text { U.S.S.R. }\end{array}$ & $\begin{array}{l}\text { SLABOSPITSKII }(1980) . \\
\text { SLABOSPITSKII }(1980) . \\
\text { SLABOSPITSKII }(1980) .\end{array}$ \\
\hline \multicolumn{4}{|l|}{ Aleurodids } \\
\hline Trialeurodes vaporariorum (Westwood) & cucurbits & U.S.S.R. & LYASHOVA (1981). \\
\hline Various prey & pine & U.S.S.R. & Molchanov (1981). \\
\hline
\end{tabular}

(LAKHIDOV, 1970). T. vigintiduopunctata is not only a predator; it feeds on the spores and mycelium of various injurious fungi, mainly on powdery mildew, Erysiphe graminis $f$. tritici, infesting wheat in Bulgaria (KUNOVSKI, 1969).

\section{b) Carabidae}

Only one Carabid predator was occasionally encountered on pear trees at Toulouse and Avignon, Demetrias atricapillus (L.). This species has been 
TABLE 14

Prey of Coccinella septempunctata $L$. (other than pear psylla), noted in recent literature.

Proies de $\mathrm{C}$. septempunctata (sauf les psylles du poirier), signalées récemment dans la littérature.

\begin{tabular}{|c|c|c|c|}
\hline Prey & Host plants & Location & References \\
\hline \multicolumn{4}{|l|}{ Aphids } \\
\hline \multirow[t]{4}{*}{ Aphis craccivora Koch } & groundnut & India & $\begin{array}{l}\text { Talati \& Butani (1979), BakHetia \& } \\
\text { SidHU (1977). }\end{array}$ \\
\hline & liquorice & U.S.S.R. & KESTEN (1975). \\
\hline & leguminous crops & Pakistan & HAMID et al. (1977). \\
\hline & vetch & U.S.A. & TEDders \& ANGALET (1981). \\
\hline \multirow[t]{3}{*}{ Aphis gossypii Glover } & citrus & Italy & Barbagallo \& Patti (1983). \\
\hline & cucumber & U.S.S.R. & YARKULOV (1978). \\
\hline & cotton & China & Wu et al. (1981). \\
\hline Aphis gossypii complex & chilli & India & AGARWALA \& RAYCHAUDHURI (1981). \\
\hline \multirow[t]{3}{*}{ Aphis fabae Scopoli } & sugar-beet & England & HEATHCOTE (1978). \\
\hline & & U.S.S.R. & GuMOVSKAYA (1982). \\
\hline & broad bean & Spain & NOTARIO et al. (1978). \\
\hline Aphis pomi DeGeer & apple & Hungary & Meszleny \& Szalay-Marzso (1979). \\
\hline Aphis citricola v. d. Goot & citrus & Italy & Barbagallo \& Patti (1983). \\
\hline Aphis sp. & potato & India & WADHI \& PARSHAD (1980). \\
\hline \multirow[t]{3}{*}{ Metopolophium dirhodum (Walker) } & wheat & England & Chambers \& Sunderland (1983). \\
\hline & & Spain & CASTANERA (1983). \\
\hline & oats, wheat & West Germany & BASEDOW (1982) \\
\hline Metopolophium festucae (Theobald) & wheat & England & CHAMBERS \& SUNDERLAND (1983). \\
\hline \multirow[t]{3}{*}{ Schizaphis graminum (Rondani) } & wheat & U.S.S.R. & $\begin{array}{l}\text { NOVOKHATKA et al. (1980), BABENKO } \\
\text { (1980). }\end{array}$ \\
\hline & & Romania & VARVARA et al. (1982). \\
\hline & rice & U.S.S.R. & MYRZIN \& LUK'YANCHIKOV (1981). \\
\hline \multirow[t]{4}{*}{ Rhopalosiphum padi (L.) } & Prunus padus $\mathrm{L}$. & West Germany & BODE $(1980 a)$ \\
\hline & wheat & Spain & CASTANERA (1983). \\
\hline & oats, wheat & West Germany & BASEDOW (1982) \\
\hline & oats & U.S.S.R. & Pukinskaya et al. (1981). \\
\hline Rhopalosiphum insertum (Walker) & apple & Hungary & MEsZleny \& Szalay-Marzso (1979). \\
\hline \multirow{3}{*}{ Acyrthosiphon pisum (Harris) } & broad bean & West Germany & GAUDCHAU (1979). \\
\hline & vetch & U.S.A. & Tedders \& Angalet (1981). \\
\hline & potato & U.S.A. & OBRYCKI et al. (1982). \\
\hline \multirow[t]{4}{*}{ Sitobion avenae $(\mathrm{F})}$. & wheat & U.S.S.R. & BABENKO (1980). \\
\hline & & England & Chambers \& Sunderland (1983). \\
\hline & & Spain & CASTANERA (1983). \\
\hline & oats, wheat & West Germany & BASEDOW (1982). \\
\hline \multirow[t]{2}{*}{ Myzus persicae (Sulzer) } & tobacco, pepper, potato & Bulgaria & GRIGOROV (1978). \\
\hline & potato & U.S.A. & ОвRускі et al. (1982). \\
\hline Brachycaudus amygdalinus (Schouteden) & peach & Iraq & MAHMOUD et al. (1981). \\
\hline Brachycaudus helichrysi (Kaltenbach) & sunflower & Yugoslavia & THALJI (1981). \\
\hline \multirow[t]{2}{*}{ Hyalopterus pruni Geoffroy } & peach & Iraq & MaHMOUd et al. (1981). \\
\hline & fruit trees & Romania & VARVARA et al. (1982). \\
\hline Dysaphis plantaginea (Passerini) & apple & Hungary & MESZleny \& Szalay-MarzSo (1979). \\
\hline Eriosoma lanigerum Hausmann & apple & Hungary & MESzleny \& Szalay-Marzso (1979). \\
\hline Diuraphis noxia (Mordvilko) & wheat & U.S.S.R. & BABENKO (1980). \\
\hline Uroleucon carthami (H.R.L.) & safflower & India & UPADHYAY et al. (1981). \\
\hline Toxoptera aurantii (Boyer) & citrus & Italy & Barbagallo \& Patti (1983). \\
\hline Brevicoryne brassicae (L.) & cabbage & U.S.S.R. & YASTREBOV (1979). \\
\hline Lipaphis erysimi (Kaltenbach) & mustard & India & SinHA et al. (1982). \\
\hline Macrosiphum euphorbiae (Thomson) & potato & U.S.A. & OBRYCKI et al. (1982). \\
\hline \multirow[t]{6}{*}{ aphids } & cereals & France & IPERTI $(1978 a)$ \\
\hline & wheat, oats, barley & U.S.S.R. & ABDULKHAIROVA (1979). \\
\hline & cotton & U.S.S.R. & ADASHKEVICH et al. (1981). \\
\hline & lucerne, clover & Czechoslovakia & HONEK (1982). \\
\hline & low-growing plants & France & IPERTI $(1978 b)$ \\
\hline & & Czechoslovakia & ZELENY (1978). \\
\hline \multicolumn{4}{|l|}{ Lepidoptera } \\
\hline Plutella xylostella (L.) & cabbage & U.S.S.R. & SLABOSPITSKII (1980). \\
\hline Artogeia rapae (L.) & cabbage & U.S.S.R. & SLABOSPITSKII (1980). \\
\hline Mamestra brassicae (L.) & cabbage & U.S.S.R. & SLABOSPITSKII (1980). \\
\hline Heliothis armigera (Hubner) & cotton & U.S.S.R. & Rustamova (1981). \\
\hline leafrollers & raspberry & U.S.S.R. & BATASHEVA (1981). \\
\hline Diptera & & & \\
\hline Contarinia sorghicola (Coquillett) & sorghum & India & THONTADARYA et al. (1979). \\
\hline Coleoptera & & & \\
\hline Sitona spp. & beet & U.S.S.R. & RYBCHIN (1982). \\
\hline Various prey & apple & Norway & SKANLAND (1981). \\
\hline & & Hungary & RADWAN \& Lovei (1982). \\
\hline & & Sweden & NORDLANDER (1977). \\
\hline & lucerne & Iraq & KHALIL et al. (1979). \\
\hline
\end{tabular}


recorded as a general predator on small insects in orchards, (STEINER, 1974 ; LivSHITS \& MitrofANOV, $1981 b$ ). It was also recorded in England as a predator of cereal aphids (SUNDERLAND, 1975 ; SUNDERLAND $\&$ VICKERMAN, 1980) and of the chrysomelid Gastrophysa polygoni (L.) on knot grass (Polygonum aviculare L.) and black bindweed ( $P$. convolvulus L.) in cereal fields (SOTHERTON, 1982). In Italy, it was noted as a predator of the curculionid Ceuthorrhynchus rapae Gyllenhal on hemp (Cannabis sativa) (TREMBLAY, 1968).

\section{Neuroptera}

\section{a) Chrysopidae}

Chrysoperla carnea (Stephens) was abundant in all pear orchards examined (table 2). Larvae of this chrysopid have already been noted as predator of pear psylla in Europe (table 1), in the U.S.A. and in Canada, and as predator on many other pests in many other countries as well (table 15).

Anisochrysa prasina (Burmeister) was captured in very small numbers on pear trees at Avignon. This chrysopid was already recorded from southeastern France as predator of olive pests (ALROUECHDi et al., $1981 b$ ) and as predator of eggs of Tortrix viridana (L.) (Lep. : Tortricidae) on Quercus ilex L. and Quercus pubescens Willd. (DU MERLE, 1983).

Anisochrysa picteti (Mc Lachlan) was also very rare in orchards at Avignon. It is definitely a mediterranean specics, exclusively xerophilous, limited to warm habitats of dense vegetation (CANARD, pers. com.).

\section{b) Hemerobiidae}

Hemerobius humulinus L. was present on pear and hawthorn surrounding the orchards at Avignon and Toulouse (table 2). This very polyphagous predator is widely distributed all over the world. In apple orchards, it attacks aphids and $P$. ulmi (PRINCIPI \& CANARD, 1974 ; SZABO \& SZENTKIRALYI, 1981; ZELENY, 1978), and in the U.S.A., it attacks Cydia pomonella (L.), and Anuraphis plantaginea (Passerini) (HoldsworTH, 1970 $a, b$ ). It has also been noted in grape vineyards in the U.S.A. (JUBB \& MASTELLER, 1977), in windbreaks in the U.S.S.R. (TSYBUL'SKAYA et al., 1977) and in cotton fields in China (CHAO \& CHANG, 1978).

Wesmaelius subnebulosa (Stephens) was very rare on pear trees at Avignon. This hemerobiid has previously been noted in apple orchards in Hungary (SZABO \& SZENTKIRALYI, 1981).

Sympherobius pygmaeus (Rambur) was also very rare in pear orchards at Avignon. This hemerobiid was already known as a predator of the coccid, Trabutina leonardii Silvestri, infesting Tamarix africana Webb. in Italy (MONACO, 1977).

\section{c) Coniopterygidae}

Coniopteryx borealis Tjeder was the one coniopterygid found on pear trees at Avignon and Toulouse. It was also collected on hawthorn infested with psyllids (table 2). Coniopterygids are known as predators of aleurodids, aphids, coccids and mites on many plants, especially on apple (PRINCIPI \& CANARD, 1974).

\section{Diptera}

The syrphid Meliscaeva auricollis (Meigen) was found in small numbers on pear trees at Toulouse. This species has already been recorded as a predator of aphids on pome and stone fruit trees in Turkey (ERKIN, 1982) and of A. pomi, Dysaphis plantaginea (Passerini) and Eriosoma lanigerum Haussmann in apple orchards in Italy (SETTI, 1973).

Syrphus vitripennis (Meigen) was found in low numbers on pear trees at Toulouse. According to LYON \& GoldLin DE TIEFENAU (1974), it is a very polyphagous predator, mostly aphidiphagous, as the list of its prey from the literature shows (table 16). PEK (1975) believed it to be a predator of general occurrence and not associated with a particular environment.

Some specimens of Episyrphus balteatus (DeGeer) were collected on pear trees infested with $P$. pyri at Toulouse. Rareness of the syrphid in these orchards was due to the fact that it is essentially a predator of aphids, as indicated by the list of its prey from the literature (table 17). However, it has already been noted several times in Italy as a predator of $P$. pyri (table 1).

\section{Acari}

A predacious mite of the genus Anystis was observed several times on pear trees at Avignon and Toulouse. Psyllids have previously been cited as prey of these mites, especially Psyllopsis distinguenda Edw. on ash trees and Trioza chenopodii Reut. on beet and spinach, as prey of Anystis baccarum (L.) in Czechoslovakia (LAUTERER, 1982). In orchards, $A$. baccarum was also noted as a predator of various pests in the U.S.S.R. (LIVSHITS \& MiTROFANOV, 1981a), of tortricids on apple trees in New Zealand (BAKER, 1983), and of the mite Panonychus citri (McG.) on Citrus in South Korea (KIM et al., 1978). An unidentified species of Anystis was noted as predator of the phytophagous mites, P. ulmi, B. rubrioculus and Tetranychus viennensis Zacher on fruit trees in the U.S.S.R. (PAURIEnE, 1970), and another species of Anystis, as predator of Scirtothrips aurantii Faure on citrus, in South Africa (MILNE, 1977). The genus Anystis contains very polyphagous species ; $A$. baccarum was also recorded as predator of Oulema melanopus L. on cereal crops in Sweden (BORG, 1983), and various Anystis as predators of aphids on non-crop plants in Canada (Frazer \& Nelson, 1981). Anystis species were also found on conifers in forests, as predators of Adelges spp. in India (RAO \& GHANI, 1972), and of Matsucoccus matsumurae Kuw. on pine in China (CHENG \& MING, 1979). In ornamental hedges of Euonymus japonicus Thunb. in England, Unaspis euonymi (Comstock) was observed to be preyed upon by Anystis sp. (DENNIS, 1969). 
TABLE 15

Prey of Chrysoperla carnea (Stephens) (other than pear psylla in Europe) noted in recent literature.

Proies de C. carnea (sauf les psylles du poirier en Europe), signalées récemment dans la littérature.

\begin{tabular}{|c|c|c|c|}
\hline Prey & Host plants & Location & References \\
\hline \multicolumn{4}{|l|}{ Psyllids } \\
\hline \multirow[t]{2}{*}{ Psylla pyricola (Foerster) } & pear & U.S.A. & $\begin{array}{l}\text { NickEL } \text { et al. }(1965), \text { WESTIGARD } \text { et al. } \\
\text { (1968), BURTS (1970), WESTIGARD } \\
\text { (1979). }\end{array}$ \\
\hline & & Canada & $\begin{array}{l}\text { McMulLEN \& JONG }(1967 a, 1967 b) \text {, } \\
\text { WILDE (1962). }\end{array}$ \\
\hline \multicolumn{4}{|l|}{ Aphids } \\
\hline \multirow[t]{5}{*}{ Rhopalosiphum padi (L.) } & Prunus padus L. & West Germany & BODE $(1980 a)$ \\
\hline & maize & France & Moreau (1983). \\
\hline & oats & Finland & RAUTAPAA (1977). \\
\hline & wheat & West Germany & Hellpap (1982). \\
\hline & & Spain & CASTANERA (1983). \\
\hline \multirow{2}{*}{ Schizaphis graminum (Rondani) } & cereals & U.S.S.R. & BEREST $(1980 b)$ \\
\hline & rice & U.S.S.R. & MYRZIN \& LUK'YANCHIKOV (1981). \\
\hline \multirow[t]{4}{*}{ Sitobion avenae $(\mathrm{F})}$. & cereals & U.S.S.R. & BEREST $(1980 b)$ \\
\hline & wheat & West Germany & HELLPAP (1982). \\
\hline & & Spain & Castanera (1983). \\
\hline & & England & DEAN (1982). \\
\hline \multirow[t]{2}{*}{ Metopolophium dirhodum (Walker) } & wheat & West Germany & HeLLPAP (1982). \\
\hline & & Spain & Castanera (1983). \\
\hline \multirow{6}{*}{$\begin{array}{l}\text { Diuraphis noxia (Mordvilko) } \\
\text { Aphis craccivora Koch } \\
\text { Aphis gossypii Glover }\end{array}$} & cereals & U.S.S.R. & BEREST $(1980 b)$ \\
\hline & liquorice & U.S.S.R. & KESTEN (1975). \\
\hline & cotton & Egypt & HABIB et al. (1980). \\
\hline & & Pakistan & AfZAL \& KHAN (1978). \\
\hline & & U.S.S.R. & $\begin{array}{l}\text { RADZIVILOVSKAYA (1980), ISHANKULIEVA } \\
\text { (1979). }\end{array}$ \\
\hline & clover & Egypt & AfIFI et al. $(1980)$ \\
\hline \multirow[t]{2}{*}{ Brevicoryne brassicae (L.) } & cabbage & England & AKINLOSOTU (1978). \\
\hline & & U.S.S.R. & YASTREBOV (1979). \\
\hline Acyrthosiphon pisum (Harris) & lucerne & U.S.A. & BAUMGAERTNER et al. (1981). \\
\hline Myzus persicae (Sulzer) & potato & U.S.A. & MACK \& SMILOWITZ (1979). \\
\hline Illinoia pepperi (Mac Gillivray) & blueberry & U.S.A. & WHALON \& ELSNER (1982). \\
\hline Hyalopterus pruni (Geoffroy) & peach & Iraq & MAHMOUD et al. (1981). \\
\hline Brachycaudus amygdalinus (Schouteden) & peach & Iraq & MAHMOUD et al. (1981). \\
\hline \multicolumn{4}{|l|}{ Coccids } \\
\hline \multirow{3}{*}{$\begin{array}{l}\text { Saissetia oleae (Olivier) } \\
\text { Aspidiotus nerii Bouché }\end{array}$} & olive & France & ALROUECHDi et al. (1980). \\
\hline & olive & Greece & ARGYRIOU \& KoURMADAS (1980). \\
\hline & & Chile & MATTA (1979). \\
\hline Hemiberlesia lataniae (Signoret) & olive & Chile & MATTA (1979). \\
\hline Planococcus citri (Risso) & grapefruit & Israel & BERLINGER et al. (1979). \\
\hline \multirow{2}{*}{$\begin{array}{l}\text { Pulvinaria innumerabilis (Rathvon) } \\
\text { coccids spp. }\end{array}$} & urban shade trees & U.S.A. & ANONYMOUS (1982). \\
\hline & citrus & France & PANIS (1980). \\
\hline \multicolumn{4}{|l|}{ Aleurodids } \\
\hline Bemisia tabaci (Gennadius) & cotton & Egypt & HAFEz et al. (1983). \\
\hline Lepidoptera & & & \\
\hline Prays oleae (Bernard) & olive & France & AlROUECHDI et al. (1981a). \\
\hline & & Syria & ALROUECHDI (1981). \\
\hline Heliothis armigera (Hubner) & cotton & U.S.S.R. & $\begin{array}{l}\text { RUSTAMOVA (1981), SUKHORUCHENKO et } \\
\text { al. (1981). }\end{array}$ \\
\hline & & Israel & BAR et al. (1979). \\
\hline & & Egypt & ISMAIL \& SWAILEM (1976). \\
\hline Heliothis zea (Boddie) & cotton & U.S.A. & WiLSON \& GuTIERREZ (1980). \\
\hline & & Turkey & KISMIR \& SENGONCA (1981). \\
\hline Heliothis virescens $(\mathrm{F})$. & cotton & Turkey & KISMIR \& SENGONCA (1981). \\
\hline Heliothis spp. & cotton & U.S.A. & SмIтH et al. (1978). \\
\hline Pectinophora gossypiella (Saunders) & cotton & Egypt & ABUL-NASR et al. (1978). \\
\hline Trichoplusia ni (Hubner) & cotton & U.S.A. & WILSON \& GUTIERREZ (1980). \\
\hline Spodoptera littoralis (Boisduval) & cotton & Egypt & $\begin{array}{l}\text { MAHER-Al.l et al. (1983), НАВIB et al. } \\
(1980) \text {. }\end{array}$ \\
\hline Spodoptera praefica (Grote) & lucerne & U.S.A. & BISABRI-ERSHADI \& EHLER (1981). \\
\hline Gymnoscelis rufifasciata Haworth & artichoke & Egypt & SADDIK \& EL-MINIAWI (1978). \\
\hline Tortrix viridana $(\mathrm{L})$. & Quercus ilex $\mathrm{L}$. & France & Du MERLE (1983). \\
\hline Coleoptera & & & \\
\hline Leptinotarsa decemlineata (Say) & potato, egg plant & U.S.S.R. & FiLIPPOV (1982). \\
\hline Hypera brunneipennis (Boheman) & tomato & Egypt & AfrFi et al. (1980). \\
\hline Diptera & & & \\
\hline Pegomya hyoscyami (Panzer) & sugar-beet & West Germany & GROH \& TANKE (1980). \\
\hline
\end{tabular}


Table 15 (continued)

\begin{tabular}{|c|c|c|c|}
\hline Prey & Host plants & Location & References \\
\hline \multicolumn{4}{|l|}{ Thrips } \\
\hline \multirow[t]{2}{*}{ Thrips tabaci Lindemann } & cotton & Egypt & НАВIB et al. (1980). \\
\hline & clover & Egypt & AFIFI et al. (1980). \\
\hline \multicolumn{4}{|l|}{ Acari } \\
\hline Tetranychus urticae Koch & cotton & U.S.S.R. & ISHANKULIEVA (1979). \\
\hline Eotetranychus pruni (Oudm.) & orchards & U.S.S.R. & KaRTASHEVA \& Lesteva (1979). \\
\hline
\end{tabular}

TABLE 16

Prey of Syrphus vitripennis (Meigen), noted in recent literature.

Proies de $\mathrm{S}$. vitripennis, signalées récemment dans la littérature.

\begin{tabular}{|c|c|c|c|}
\hline Prey & Host plants & Location & References \\
\hline \multicolumn{4}{|l|}{ Aphids } \\
\hline Myzus persicae (Sulzer) & cucumber & U.S.S.R. & KARELIN (1980). \\
\hline Myzus humuli (Schrank) & $\begin{array}{l}\text { green vegetables } \\
\text { plum }\end{array}$ & $\begin{array}{l}\text { Bulgaria } \\
\text { Poland }\end{array}$ & $\begin{array}{l}\text { NATSKOVA (1977). } \\
\text { WIACKOWSKI \& WIACKOWSKA (1968). }\end{array}$ \\
\hline Myzus cerasi $(\mathrm{F})$. & $\begin{array}{l}\text { pium } \\
\text { cherry }\end{array}$ & Poland & $\begin{array}{l}\text { WIACKOWSKI \& WIACKOWSKA (1968). } \\
\text { WIACKOWSKI \& WIACKOWSKA (1968). }\end{array}$ \\
\hline Myzus cerasi pruniavium Börner & cherry & Poland & WIACKOWSKI \& WIACKOWSKA (1968). \\
\hline Capitophorus ribis (L.) & currants & Poland & WIACKOWSKI \& WIACKOWSKA (1968). \\
\hline Brachycaudus cardui (L.) & plum & Poland & WIACKOWSKI \& WIACKOWSKA (1968). \\
\hline Brachycaudus helichrysi (Kaltenbach) & plum & Poland & WIACKOWSKI \& WIACKOWSKA (1968). \\
\hline Rhopalosiphum oxyacanthae (Schrank) & apple & Poland & WIACKOWSKI \& WIACKOWSKA (1968). \\
\hline Rhopalosiphum nymphaeae (L.) & plum & Poland & WIACKOWSKI \& WIACKOWSKA (1968). \\
\hline Rhopalosiphum padi (L.) & Prunus padus $\mathrm{L}$. & U.S.S.R. & CHERKASHINA (1973). \\
\hline \multirow[t]{2}{*}{ Aphis pomi DeGeer } & apple & Italy & SETTI (1973). \\
\hline & & Poland & WIACKOWSKI \& WIACKOWSKA (1968). \\
\hline Aphis schneideri (Börner) & currants & Poland & WIACKOWSKI \& WIACKOWSKA (1968). \\
\hline \multirow{2}{*}{ Aphis gossypii Glover } & cucumber & U.S.S.R. & KARELIN (1980). \\
\hline & green vegetables & Bulgaria & NATSKOVA (1977). \\
\hline Aphis craccivora Koch & green vegetables & Bulgaria & NATSKOVA (1977). \\
\hline \multirow[t]{2}{*}{ Aphis fabae Scopoli } & green vegetables & Bulgaria & NATSKOVA (1977). \\
\hline & sugar-beet & France & LYON (1971). \\
\hline Aphis sambuci $\mathrm{L}$. & ornamental shrubs & Poland & ZIARKIEWICZ \& KoZLOWSKA (1973). \\
\hline Anoecia corni $(\mathrm{F})$. & ornamental shrubs & Poland & ZIARKIEWICZ \& KOZLOWSKA (1973). \\
\hline Macrosiphum rosae $(\mathrm{L})$. & ornamental shrubs & Poland & ZIARKIEWICZ \& KOZLOWSKA (1973). \\
\hline \multirow[t]{2}{*}{ Macrosiphum euphorbiae (Thomas) } & cucumber & U.S.S.R. & KARELIN (1980). \\
\hline & green vegetables & Bulgaria & Natskova (1977). \\
\hline Acyrthosiphon pisum (Harris) & green vegetables & Bulgaria & Natskova (1977). \\
\hline Eriosoma lanigerum (Hausmann) & apple & Italy & SETTI (1973). \\
\hline Eriosoma ulmi (L.) & $\mathrm{elm}$ & Poland & JANISZEWSKA-СICHOCKA (1971). \\
\hline \multirow{2}{*}{ Disaphis plantaginea (Passerini) } & apple & Italy & SETTI (1973). \\
\hline & & Poland & $\begin{array}{l}\text { WNUK (1972), WIACKOWSKI \& WIAC- } \\
\text { KOWSKA (1968). }\end{array}$ \\
\hline \multirow[t]{2}{*}{ Hyalopterus pruni (Geoffroy) } & peach & France & REMAUDIERE \& LECLANT (1971). \\
\hline & plum & Poland & SMOLARZ (1970) \\
\hline \multirow[t]{2}{*}{ Brevicoryne brassicae (L.) } & green vegetables & Bulgaria & NATSKOVA (1977). \\
\hline & cultivated crucifers & Rumania & CONSTANTINESCu (1972). \\
\hline \multirow[t]{3}{*}{ Amphorophora lactucae (L.) } & fruit trees, ornamen- & & \\
\hline & tal shrubs & Poland & KOZLOWSKA (1978), WNUK (1972). \\
\hline & currants & Poland & WIACKOWSKI \& WIACKOWSKA (1968). \\
\hline \multirow[t]{2}{*}{ aphids spp. } & cabbage & Czechoslovakia & DUSEK \& LASKA (1974). \\
\hline & $\begin{array}{l}\text { pome } \& \text { stone fruit } \\
\text { trees }\end{array}$ & Turkey & ERKIN (1983). \\
\hline \multicolumn{4}{|l|}{ Psyllids } \\
\hline \multirow{5}{*}{$\begin{array}{l}\text { Craspedolepta dorecinia sp. } \mathrm{n} \text {. } \\
\text { Craspedolepta chasanica sp. } \mathrm{n} \text {. } \\
\text { Calophya nigra Kuway. }\end{array}$} & Artemisia spp. & U.S.S.R. & KonOVALOVA (1978). \\
\hline & $\begin{array}{l}\text { Artemisia spp. } \\
\text { Phellodendron }\end{array}$ & U.S.S.R. & KonOVALOVA (1978). \\
\hline & $\begin{array}{l}\text { Phellodendron } \\
\text { sachalinense }\end{array}$ & & \\
\hline & $\begin{array}{l}\text { F. Schmidt., } \\
\text { Phellodendron }\end{array}$ & & \\
\hline & amurense Rupr. & U.S.S.R. & KonOVALOVA (1978). \\
\hline
\end{tabular}


TABLE 17

Prey of Episyrphus balteatus (DeGeer) (other than pear psylla), noted in recent literature.

Proies $d$ 'E. balteatus (sauf les psylles du poirier), signalées récemment dans la littérature.

\begin{tabular}{cccc}
\hline \hline Prey & Host plants & Location & References \\
\hline
\end{tabular}

Aphids

Acyrthosiphon pisum (Harris)

Anoecia corni (F.)

Aphis craccivora Koch

Aphis fabae Scopoli

Aphis gossypii Glover

Aphis pomi DeGeer

Aphis sambuci L.

Aphis spiraephaga Müller

Brachycaudus amygdalinus (Schouteden)

Brachycaudus helichrysi (Kaltenbach)

Brevicoryne brassicae (L.)

Cinara pilicornis (Hartig)

Dysaphis plantaginea (Passerini)

Eriosoma lanigerum (Haussmann)

Eriosoma ulmi (L.)

Hyalopterus pruni (Geoffroy)

Hysteroneura setariae (Thomas)

Lachnus tropicalis (v. d. Goot)

Lipaphis erysimi Kaltenbach

Macrosiphum euphorbiae (Thomas)

Macrosiphum rosae (L.)

Metopolophium dirhodum (Walker)

Metopolophium festucae (Theobald)

Myzus persicae (Sulzer)

Pemphigus fuscicornis (Koch)

Rhopalosiphum insertum (Walker)

Rhopalosiphum padi (L.)

Schizaphis graminum (Rondani)

Schizaphis hypersiphonata Basu

lucerne
green vegetables
broad bean
ornamental shrubs
green vegetables
broad bean
sugar-beet
ornamental shrubs
green vegetables
green vegetables
cucumber
apple

ornamental shrubs ornamental shrubs ornamental shrubs almond

almond

cabbage

brussels sprouts cultivated crucifers green vegetables

tobacco

spruce

apple

apple

elm

plum

peach

peach

chestnut

cabbage

Eruca sativa (Miller) green vegetables cucumber

roses

ornamental shrubs

cereals

wheat

wheat

tobacco

green vegetables

cucumber

cabbage

peach

E. sativa

sugar-beet

apple

wheat

maize

Prunus padus L.

maize

rice

pangola grass
Bulgaria

Bulgaria

West Germany

Poland

Bulgaria

England

France

Poland

Bulgaria

Bulgaria

U.S.S.R.

France

Italy

Poland

Poland

Poland

Poland

Lebanon

Lebanon

Czechoslovakia

Bulgaria

U.S.S.R.

England

Rumania

Bulgaria

Japan

Czechoslovakia

France

Italy

France

Italy

Poland

Poland

France

Taiwan

Japan

Pakistan

India

India

Bulgaria

U.S.S.R.

Bulgaria

Poland

England

Belgium

West Germany

England

Belgium

England

England

Japan

Bulgaria

Bulgaria

U.S.S.R.

India

Japan

France

Bulgaria

India

Bulgaria

France

Belgium

Poland

U.S.S.R.

West Germany

Poland

U.S.S.R.

Australia
ABdulmadzhid (1973).

NATSKOVA (1977).

TANKE (1976).

ZiARKIEWICZ \& KoZlowSKa (1973).

NATSKOVA (1977).

ChandLer (1968).

LYON (1971).

ZIARKIEWICZ \& KoZLOWSKa (1973).

NATSKOVA (1977).

NATSKOVA (1977).

KARELIN (1980).

Lyon \& Goldlin de TiefENAU (1974),

MARBOUTIE (1976).

SETTI (1973).

WNUK (1977).

ZIARKIEWICZ \& KOZLOWSKA (1973).

ZiARKIEWICZ \& KOZLOWSKA (1973).

ZIARKIEWICZ \& KOZIOWSKA (1973).

TALHOUK (1977).

TALHOUK (1977).

LASKA (1967).

TSACHeV (1972), StRaka (1976).

SHLYAKHOVOI \& BoBONICH (1975), YASTREBOV (1979).

Pollard (1969).

CONSTANTINESCU (1972).

NATSKOVA (1977).

TAKAOKA (1975).

KuLA (1982)

Lyon \& Goldlin de Tiefenau (1974).

SeTTI (1973).

Lyon \& GoldLin de Tiefenau (1974).

SETTI (1973).

JANISZEWSKA-CICHOCKA (1971).

SMOLARZ (1970).

Remaudiere \& Leclant (1971).

LEE \& Hsu (1979).

Togoshi (1976).

Khan \& Yunus (1970).

Roy \& Basu (1978), Agarwala \& Ray.

CHAUDHURI (1981).

BAKHETIA \& SHARMa (1979).

NATSKOVA (1977).

KARELIN (1980).

NATSKOVA (1971).

ZIARKIEWICZ \& KOZLOWSKa (1973).

DEAN (1974).

LATTEUR (1973).

BODE (1980b).

Chambers et al. (1982).

LATTEUR (1973).

Chambers et al. (1982).

ChAMBers et al. (1982).

TAKAOKA (1975).

Dirimanov \& Dimitrov (1975).

NATSKOVA (1977).

KARELIN (1980).

AGARWALA \& RAYCHAUDHURI (1981).

ITO \& IWAO (1977).

Renaudiere \& LeClant (1971).

GRIGOROV (1978).

BaKHETIA \& Sharma (1979).

GRIGOROV (1977b).

LyON \& GOLDLIN DE TIEFENAU (1974).

LATTEUR (1973).

JASIOLEK et al. (1974).

Cherkashina (1973).

BODE (1980b).

JASIOLEK et al. (1974).

MYRZIN \& LUK'YANCHIKOV (1981).

BROADLEY \& ROGERS (1978). 
Table 17 (continued)

\begin{tabular}{|c|c|c|c|}
\hline Prey & Host plants & Location & References \\
\hline \multirow[t]{5}{*}{ Sitobion avenae $(\mathrm{F})}$. & wheat & Belgium & LATTEUR (1973). \\
\hline & & West Germany & BodE $(1980 b)$ \\
\hline & & England & Chambers et al. (1982), DEAN (1982). \\
\hline & maize & Poland & JASIOLEK et al. (1974). \\
\hline & cereals & England & DEAN (1974). \\
\hline \multirow{7}{*}{$\begin{array}{l}\text { Toxoptera aurantii (Boyer) } \\
\text { aphids spp. }\end{array}$} & citrus & Greece & ARGYRIOU (1970). \\
\hline & $\begin{array}{l}\text { fruit trees, bushes } \\
\text { pome \& stone fruit }\end{array}$ & Poland & WNUK (1983). \\
\hline & trees & Turkey & ERKIN (1983). \\
\hline & pepper & Bulgaria & NATSKOVA (1973). \\
\hline & sorghum, maize, & & \\
\hline & mustard, cole & India & PATNAIK et al. (1977). \\
\hline & tea, fennel, Malus & Azores & Gomes (1980). \\
\hline Various prey & cotton & U.S.S.R. & NARZIKULOV \& UMAROV (1975). \\
\hline
\end{tabular}

Another predacious mite Allothrombium fuliginosum Hermann was common in the orchards at Toulouse and Avignon and observed as a predator of $P$. pyri. A. fuliginosum has been noted in the literature as predator of a large variety of prey. In orchards in Italy, it was observed preying upon winter eggs of the aphid, D. plantaginea, on apple (BARONIO, 1971) and upon the coccid Filippia follicularis Targioni, on olive (SCALTRITI, 1982). It was also observed in the U.S.S.R. as a predator of eggs of Leptinotarsa decemlineata (Say) (KOVAL, 1968) and of $A$. craccivora on liquorice (KESTEN, 1975). Also, it was observed attacking Pegomya betae (Curtis) on sugar beet in France (MISSONNIER, 1971) and B. brassicae on cultivated crucifers in Rumania (CONSTANTINESCU, 1972).

\section{Fungi}

We did not encounter $P$. pyri larvae infected with fungi, although some cases of attack by Entomophthora sp. are already known in France and Italy (table 1). On the other hand, we did find a few $P$. peregrina larvae parasitized by Entomophthora sp. in the Paris region.

\section{DISCUSSION \& CONCLUSION}

Among the 66 species inventoried, 56 had a useful role, to varying degrees, in limitating populations of pear psylla. Only 16 species were fairly abundant and seem to be especially appropriate for biological control. Among these are the 3 species traditionally well tied to pear psylla, $P$. mitratus, $T$. psyllae and $A$. nemoralis, plus 13 predators as follows :

$A$. nemorum, O. horvathi, O. vicinus, $H$. meriopterum, C. virgula, O. nassatus, S. punctillum, S. ru- bromaculatus, S. subvillosus, C. septempunctata, $C$. carnea, $C$. borealis and $A$. fuliginosum.

The main beneficial insects for biological control of pear psylla were also found on hawthorn where they also attack psyllids ; moreover, 2 predators common on pear trees, $A$. nemorum and $H$. meriopterum, abundantly frequented nettle attacked by $T$. urticae and aphids inside or surrounding the orchards. Not only hawthorn and nettle, but mainy other host plants serve as a reservoir for the beneficial insects occurring in pear orchards. The richness of the orchard's natural environment may have contributed to maintain and to increase the population of pear psylla natural enemies.

The main enemies mentioned above are not active during the total development of the 5 to 7 generations of $P$. pyri which occur in France. Some species occur early in the season and others later, in such a way that the limitating combined and complementary action of these enemies definitely covers almost the entire season (HERARD, 1985).

This literature review shows that the inventoried species are basically polyphagous. The parasites, $P$. mitratus and $T$. psyllae, attack various psyllids, and the main predators are either common in various kinds of orchards, or predaceous on insects of a particular taxonomic group, such as aphids, which have a wide spectrum of host plants.

This lack of specificity for the pear psylla among its enemies must be considered if using any of them in biological control. It remains to be seen whether any of these beneficial species could survive on a diet of largely pear psylla, would lead themselves to economical mass production in the laboratory, would disperse, too, rapidly considering their apparent need for diversity, to effect control of the pest and could be applied when and where needed in adequate quantity. 


\section{ACKNOWLEDGEMENTS}

We thank J.-P. MANGUIN and J.-R. ORTIZ who authorized insect collections in their orchards at Avignon and at Toulouse. We wish to express our heartiest gratitude to M.M. P. ATCER (I.N.R.A., St Marcel-les-Valences) and C. Al.AUzet (Université Paul Sabatier, Toulouse) for introducing us to scientists working on psyllids in France, NGuyen Thanh Xuan (C.N.R.S., Toulouse), B. Bouyjou (E.N.S.A.T.), R. Rieux, F. D'ARCIER (I.N.R.A., Montfavet) who gave us very useful information on the psylla biocomplex. Also, we very warmly thank G. Delvare (G.E.R.D.A.T., Montpellier), G. Fauvel (I.N.R.A., Montpellier), G. IPERTI (I.N.R.A., Valbonne), M. Canard (Université Paul Sabatier, Toulouse), J. CARAYON (Museum National d'Histoire Naturelle, Paris), P. DesSart (Institut Royal des Sciences Naturelles de Belgique), Z. BouceK, J. S. Noyes, J. Quinlan (British Museum, London), L. KNutson, M. E. Schauff, F. C. ThOmpson (S.E.L., IIBII, U.S.D.A.) for identification of pear psylla enemies. Finally, we thank R. RiEUX, G. Fauvel, P. Atger and B. D. Perkins (E.P.L., U.S.D.A., A.R.S., Béhoust), who reviewed our manuscript.

\section{REFERENCES}

Abdel-Salam F., 1967. Uber die Wirkung von Phosphorsäureestern auf einige Arthropoden innerhalb der Apfelbaum-Biozönose in Abhängigkeit von ihrer Dichte. Z. angew. Zool., 54 (2), 233-283.

Abdulkhairova S., 1979. The injuriousness of cereal aphids. Zashch. Rast., 10, 44 (in russian).

Abdulmadzhid A. A., 1973. Control of Acyrthosiphon pisum with natural enemies and insecticides. Rast. Zashch., 21 (7), 39-41 (in bulgarian)

Abul-Nasr S. E., Tawfik M. F. S., Ammar E. D., Farrag S. M., 1978. Occurrence and causes of mortality among active and resting larvae of Pectinophora gossypiella (Lep: Gelechiidae) in Giza, Egypt. Z. Angew. Entomol., 86 (4), 403-414.

Adashkevich B. P., Adylov Z. K., Rasulev F. K., 1981. The biomethod in action. Zashch. Rast., 9, 9-10 (in russian).

Afifi A. M., Farghali H. T., Rezk G. N., Ragab Z. A., 1980. Seasonal abundance of certain pests and predators in clover fields in Egypt. Bull. Entomol. Soc. Egypt., 60, 273-278.

Afzal M., Khan M. R., 1978. Life history and feeding behaviour of green lacewing, Chrysopa carnea Stephens (Neu : Chrysopidae). Pakistan J. Zool., 10 (1), 83-90.

Agarwala B. K., Raychaudhuri D. N., 1981. Note on some aphids affecting economically important plants in Sikkim. Indian J. Agr. Sci., 51 (9), 690-692.

Agekyan N. G., 1977. Clitostethus arcuatus Rossi (Col. Coccinellidae) - a predator of citrus whitefly in Adzharia. Entomol. Obozrenie, 56 (1), 31-33 (in russian).

Akinlosotu T. A., 1978. The inter-relationship of the cabbage aphid parasite, Diaereliella rapae McIntosh (Hym. : Aphididae) and the entomophagous predators of the aphid. Nigerian J. Entomol., 3 (1), $5-9$

Akramovskaya E. G., 1978. The biology of some predatory bugs of the family Anthocoridae in the conditions of the Ararat valley in Armenia. Biol. Z. Armenii, 31 (9), 959-964 (in russian).

Alekseev Y. I., Niyazov O. D., 1975. Composition and seasonal dynamics of numbers of predacious arthropods on cotton in the Murgab lowlands. Izvestiya Akademii Nauk Turkmenskoi SSR, Biologicheskikh Nauk, 5, 57-64 (in russian).

Alrouechdi K., 1981. Relations comportementales et trophiques entre Chrysoperla carnea (Stephens) (Neu. : Chrysopidae) et trois principaux ravageurs de l'olivier. I. La teigne de l'olivier Prays oleae Bern. (Lep. : Hyponomeutidae). Neuroptera International, 1 (3), 122-134

Alrouechdi K., Canard M., Pralavorio R., Arambourg Y., 1980. Répartition des adultes et des pontes de chrysopides (Neuroptera) récoltés dans une oliveraie de Provence. Neuroptera International, 1 (2), 65-74.

Alrouechdi K., Canard M., Pralavorio R., Arambourg Y., 1981a. Influence du complexe parasitaire sur les populations de Chrysopides (Neuroptera) dans un verger d'oliviers du Sud-Est de la France. Z. Angew. Entomol., 91 (4), 411-417.

Alrouechdi K., Pralavorio R., Canard M., Arambourg Y., $1981 \mathrm{~b}$. Coïncidence et relations prédatrices entre Chrysopa carnea (Stephens) (Neur. : Chrysopidae) et quelques ravageurs de l'olivier dans le Sud-Est de la France. Mitt. Schw. Entomol. Gesel., 54 (3), 281-290.

Altay M., Gurses A., Uyar K., 1973. Studies on scale insects (Coccoidea) in the Marmara region. Uzerinde calismalar, 29, 155.
Anderson N. H., 1962a. Growth and fecundity of Anthocoris spp. reared on various prey (Het. : Anthocoridae). Entomol. exp. appl., $5,40-52$.

Anderson N., H., 1962b. Studies on overwintering of Anthocoris (Hem. : Anthocoridae). Entomol. Mon. Mag., 98, 1-3.

Anderson N. H., 1962c. Bionomics of six species of Anthocoris (Het. : Anthocoridae) in England. Trans. R. entomol. Soc. Lond., $114(3), 67-95$

Anonymous, 1982. Biocontrol of cottony maple scale on urban shade trees. IPM Practitioner, 4 (10), 3.

Arcanin B., Balarin I., 1973. Predatory species of Heteroptera represented in the fauna of Croatian apple orchards. Acta Entomol. Jugoslavica, 8 (1/2), 11-21 (in yugoslavian).

Archer T. L., Cate R. K., Eikenbary R. D., Starks K. J., 1974. Parasitoids collected from greenbugs and corn leaf aphids in Oklahoma in 1972. Ann. Entomol. Soc. Am., 67 (1), 11-14.

Argyriou L. C., 1970. Les aphides nuisibles aux agrumes en Grèce et leurs ennemis naturels. Ann. Inst. Phytopathol. Benaki, 9 (2), 114-117.

Argyriou L. C., Katsoyannos P., 1977. Coccinellid species found in the olive groves of Greece. Ann. Inst. Phytopathol. Benaki, 11 (4), 331-345.

Argyriou L. C., Kourmadas A. L., 1980. The phenology and natural enemies of Aspidiotus nerii Bouché in central Greece. Fruits, 35 (10), 633-638.

Argyriou L. C., Paloukis S. S., 1976. Some data on biology and parasitism of Sphaerolecanium prunastri Fonscolombe (Hom. : Coccidae) in Greece. Ann. Inst. Phytopathol. Benaki, 11 (3), 230-240.

Arzone A., 1976. Indagini su Trialeurodes vaporariorum ed Encarsia tricolor in pien'aria. Inf. Fitopatol., 26 (11/12), 5-10.

Arzone A., 1979. Indagini sui limitatori naturali di Psylla pyri (L.) in Piemonte. Boll. Lab. Entomol. Agrar. Portici, 36, 131-149.

Asgari A., 1966. Untersuchungen über die im Raum StuttgartHohenheim als wichtigste Prädatoren der grünen Apfelblattlaus (Aphidula pomi Deg.) auftretenden Arthropoden. Z. angew. Zool., 53 (1), 35-93.

Atger P., 1977. Le psylle du poirier est-il un faux problème ? La défense des végétaux, 187, 1-7.

Atger P., 1978. La lutte contre le psylle du poirier. Aspects nouveaux. Arboriculture fruitière, 288, 33-36.

Atger P., 1979a. Aménagement de la lutte contre les psylles du poirier dans les basses vallées du Rhône et de la Durance. C.R. Journées Fruitières d'Avignon-Montfavet, 16-17 nov. 1978, 93-99.

Atger P., 1979b. Les psylles du poirier. Biologie et contrôle en verger. Phytoma, 311, 19-22.

Atger P., Feron M., Bassino J. P., 1979. La protection intégrée en vergers de poiriers et plus particulièrement la lutte contre les psylles. Symp. Int. OILB/SROP sur la lutte intégrée en agriculture et en forêt, Wien 8-12 Oct. 1979, 313-319.

Audemard H., 1973. L'aménagement de la lutte chimique contre le carpocapse (Laspeyresia pomonella $\mathbf{L}$.) en verger de pommiers. Un premier pas dans la lutte intégrée. Rev. Zool. Agric. Pathol. Vég., $72(2), 33-47$

Austreng M. P., Somme L., 1980. The fauna of predatory bugs (Het. : Miridae and Anthocoridae) in Norwegian apple orchards. Fauna Norvegica, B, 27 (1/2), 3-8. 
Aveling C., 1981a. The role of Anthocoris species (Hem. : Anthocoridae) in the integrated control of the damson-hop aphid (Phorodon humuli). Ann. Appl. Biol., 97 (2), 143-153.

Aveling C., $1981 b$. Action of mephosfolan on anthocorid predators of Phorodon humuli. Ann. Appl. Biol., 97 (2), 155-164.

Babenko V. A., 1980. A test on the rational control of aphids. Zashch. Rast., 6, 14-15 (in russian).

Baggiolini M., Schmid A., Jucker W., Frischknecht M., 1979. Applications pratiques des régulateurs de croissance des insectes, analogues de l'hormone juvénile, contre les psylles du poirier. Mitt. Schw. Entomol. Gesel., 52 (1), 3-11.

Bagnall R. S., Harrison H., 1924. New British Cecidomyiidae. V. Entomol. Rec. J. Var., 26, 38.

Baker R. T., 1983. Predation of leafroller larvae by spiders and mites. Weta, 6 (1), 22-23.

Bakhetia D. R., Sharma A. K., 1979. Preliminary observations on aphids infestation on Eruca sativa Mill. Indian J. Entomol., 41 (3), 288-289.

Bakhetia D. R., Sidhu A. S., 1977. Biology and seasonal activity of the groundnut aphid, Aphis craccivora Koch. J. Kes., Punjab Agr. Univ., 14 (3), 299-303.

Balevski A., 1977. Natural enemies of mites. Rast. Zashch., 25 (2), 11-14 (in bulgarian).

Bar D., Gerling D., Rossler Y., 1979. Bionomics of the principal natural enemies attacking Heliothis armigera in cotton fields in Israel. Environ. Entomol., 8 (3), 468-474.

Barbagallo S., Patti I., 1983. Citrus aphids and their entomophagous in Italy. In : Aphid antagonists. Proceedings of a meeting of the EC Experts' group, Portici, Italy, 23-24 Nov. 1982 (edited by Cavalloro R.), Rotterdam, Netherlands, A. A. Balkema, 116-669.

Barnes H. F., 1930. Gall midges (Cecidomyiidae) as enemies of the Tingidae, Psyllidae, Aleurodidae and Coccidae. Bull. Entomol. Res., 21, 319-329.

Baronio P., 1971. Ricerche su un metodo di campionamento per rilevare la densita e la distribuzione delle uova di Dysaphis plantaginea Pass. (Hom. : Aphididae) in un meloto. Nota preliminare. Boll. Oss. Mal. Piante, Bologna, 2, 1-13).

Basedow T., 1982. Untersuchungen zur Populationsdynamik des Siebenpunktmarienkäfers Coccinella septempunctata L. (Col. Coccinellidae) auf Getreidefeldern in Schleswig-Holstein von 19761979. Z. Angew. Entomol., 94 (1), 66-82.

Bassino J. P., Fort G., Gendrier J. P., Reboulet J. N., 1975. Lutte intégrée en vergers de poiriers. C. R. $5^{e}$ Symp. Lutte intégrée en vergers, OILB/SROP, 153-174.

Batasheva Z. N., 1979. The raspberry beetle in the Tula region. Zashch. Rast., 6, 30-31 (in russian).

Batasheva Z. N., 1981. Leafrollers on raspberry. Zashch. Rast., 6, 41 (in russian).

Baumgaertner J. U., Gutierrez A. P., Summers C. G., 1981. The influence of aphid prey consumption on searching behavior, weight increase, developmental time, and mortality of Chrysopa carnea (Neu : Chrysopidae) and Hippodamia convergens (Col. : Coccinellidae) larvae. Can. Entomol., 113 (11), 1007-1014.

Bayan A. K., 1981. Population dynamics of the harvest apple mite on grapevine and of some acarophages. Rast. Zashch., 29 (4), 24-29 (in bulgarian).

Baylac M., 1980. Faune associée à Cryptococcus fagi (Baer.) (Hom. : Coccoidea) dans quelques hêtraies du nord de la France. Acta Oecol., Oecol. Appl., 1 (2), 199-208.

Benedek P., 1969. Causes of the collapse of a Dendrolimus pini outbreak. A zoocenological study. Acta phytopathol. Acad. Sci. hung., 4 (4), 305-311.

Berest Z. L., 1980a. Parasites and predators of the aphids Brachycolus noxius and Schizaphis graminum in crops of barley and wheat in the Nikolaev and Odessa regions. Vestnik Zoologii, 2, 80-81 (in russian).

Berest Z. L., 1980b. Entomophagous insects controlling the numbers of cereal leaf aphids in wheat fields of the steppe zone of Pravoberezh'ya, Ukrainian S.S.R. Vestnik Zoologii, 5, $84-87$ (in russian).

Berlinger M. J., Tzahor J., Gol'berg A. M., 1979. Contribution to the phenology of Chilocorus bipustulatus L. (Coccinellidae) in citrus groves and the control of Planococcus citri (Pseudococcidae) in Israel, p. 49-54. In : XXXI International Symposium on Crop Protection. Mededelingen van de Faculteit Landbouwwetenschappen Rijksuniversiteit Gent, 44 (1, I ; 2, II), 1-476 ; 477-1007.

Bisabri-Ershadi B., Ehler L. E., 1981. Natural biological control of western yellow-striped armyworm, Spodoptera praefica (Grote), in hay alfalta in northern California. Hilgardia, 49 (5), 1-23.

Blazhievskaya A. P., 1980. The variegated oak aphid and ants. Zashch. Rast., 1, 37 (in russian).

Bode E., 1980a. Untersuchungen zum Auftreten der Haferblattlaus Rhopalosiphum padi (L.) (Hom. : Aphididae) an irhem Winterwirt Prunus padus L. I. Biologie der Haferblattlaus Rhopalosiphum padi (L.) am Winterwirt. Z. Angew. Entomol., 89 (4), 363-377.

Bode E., $1980 b$. Aphids in winter wheat : abundance and limiting factors from 1976 to 1979, p. 49-57. In : Ecologie des pucerons des céréales. Réunion du sous-groupe du Groupe de Travail « Lutte intégrée en Céréales ", Colmar (France) 14-15 Nov. 1979. Bulletin OILB/SROP, 3 (4), $119 \mathrm{p}$.

Boldyrev M. I., 1968a. The apple leaf-mining moth Lithocolletis pyrifoliella. Zashch. Rast., 13 (6), 26-27 (in russian).

Boldyrev M. I., 1968b. The raspberry cane midge. Zashch. Rast., 13 (10), 35-36 (in russian).

Boldyrev M. I., 1975. Insect enemies of the lower-surface mining moth. Zashch. Rast., 1, 25 (in russian).

Bonnemaison L., 1971. Observations sur les fluctuations des populations aphidiennes du chou, de la betterave et de la pomme de terre. Ann. Soc. Entomol. Fr., (N.S.) 7 (3), 505-551.

Bonnemaison L., Missonnier J., 1956. Le psylle du poirier (Psylla pyri L.). Morphologie et biologie. Méthodes de lutte. Ann. Epiphyties, 7 (2), 263-331.

Borg A., 1983. The cereal leaf beetle (Oulema melanopa L.), some observations and tests on control. Växtskyddsnotiser, 46 (4), 74-80 (in swedish).

Botto E. N., 1981. Aphelinus asychis Walker y Aphelinus abdominalis (Dalman), dos nuevos parasitos para los «pulgones verde y amarillo de los cereales", en la Argentina. Rev. Soc. Entomol. Argentina, 39 (3/4), 197-202.

Botto E. N., Crouzel I. S. de, 1981. Contribution al conocimiento de las causas de mortalidad de la "isoca de la alfalfa " Colias lesbia (F.) en Castelar, Buenos Aires. Rev. Soc. Entomol. Argentina, $40(1 / 4), 201-210$.

Botto E. N., Hernandez M. C., Boggiatto M. E., Crouzel I. S. de, 1979. Resultados preliminares de estudios bioecologicos sobre el «pulgon amarillo de los cereales" Metopolophium dirhodum (Walker), realizados en Castelar, Buenos Aires, durante 1976 a 1979. I. Estudios de campo. Rev. Soc. Entomol. Argentina, 38 (1/4), 37-46.

Bouyjou B., Canard M., Nguyen T. X., 1984. Analyse par frappage des principaux predateurs et proies potentrelles en verger de poiriers non traité, p. 148-166. In: Colloque international sur la lutte intégrée contre les psylles du poirier, Toulouse, 27-29 Sept. 1983, Bull. OILB/SROP, VII (5), $388 \mathrm{p}$.

Broadley R. H., Rogers D. J., 1978. Pests of pangola grass in north Queensland pastures. Queensland Agric. J., 104 (4), 320-324.

Bronnimann H., 1964. Rearing anthocorids on an artificial medium. Tech. Bull. Commonw. Inst. Biol. Contr., 4, 147-150.

Burts E. C., 1970. The pear psylla in central Washington. Washington Agric. Exp. Stn. Circ. 516, 13 p.

Campbell C. A. M., 1977. A laboratory evaluation of Anthocoris nemorum and $A$. nemoralis (Hem. : Anthocoridae) as predators of Phorodon humuli (Hom. : Aphididae). Entomophaga, 22 (3), 309314.

Campbell C. A. M., 1978. Regulation of the damson-hop aphid (Phorodon humuli (Schrank)) on hops (Humulus lupulus L.) by predators. J. Hort. Sci., 53 (3), 235-242.

Carl K. P., 1969. Observations on Endopsylla agilis de Meijere (Dipt. : Cecidomyiidae), an endoparasite of Psylla spp. (Hom. : Psyllidae). Tech. bull., C.I.B.C., 12, 147-156.

Carl K. P., 1980. Beobachtungen über die Apfelgallmücke, Dasineura mali Kieffer und eine neue Art aus Apfelblattgallen, Macrolabis sp. (Dipt. : Cecidomyiidae). Anz. Schädl. Pflanz. Umw., 53 (7), 99-102.

Carl K., Zwölfer H., 1965. Untersuchungen zur biologischen 
Bekämpfung einiger unkräuter und Schädlinge in Landwirtschaft und Obstbau. 2. Bericht über die Arbeiten der Europäischen Station des Commonwealth Institute of biological control, Delémont, Schweiz. I. Teil. Anz. Schädlingsk., 38 (6), 81-87.

Castanera P., 1983. The relative abundance of parasites and predators of cereal aphids in central Spain. In : Aphid antagonists. Proceedings of a meeting of the EC Experts' Group, Portici, Italy, 23 24 Nov. 1982 (Edited by Cavalloro R.), Rotterdam, Netherlands. A. A. Balkema, 76-82.

Chambers R. J., Sunderland K. D., 1983. The abundance and effectiveness of natural enemies of cereal aphids on two farms in southern England. In : Aphid antagonists. Proceedings of a meeting of the EC Experts' Group, Portici, Italy, 23-24 Nov. 1982. (Edited by Cavalloro R.), Rotterdam, Netherlands. A. A. Balkema, 83-87.

Chambers R. J., Sunderland K. D., Stacey D. L., Wyatt I. J., 1982. A survey of cereal aphids and their natural enemies in winter wheat in 1980. Ann. Appl. Biol., 101 (1), 175-178.

Chandler A. E. F., 1968. Height preferences for oviposition of aphidophagous Syrphidae (Diptera). Entomophaga, 13 (3), 187-195.

Chao C. C., Chang S. T., 1978. Population fluctuations of green lacewings in cotton fields. Acta Entomol. Sinica, 21 (3), 271-278 (in chinese).

Chen H. Q., 1982. A preliminary observation on Altica sp. Kunchong Zhishi, 19 (6), 21-23 (in chinese).

Cheng H. Y., Ming W. J., 1979. Population dynamics and biological control of Matsucoccus matsumurae Kuwana (Hom. : Margarodidae). Acta Entomol. Sinica, 22 (2), 149-155 (in chinese).

Cherkashina A. S., 1973. The biology of some entomophagous Syrphidae (Diptera) in the Maritime Territory, p. 135-139. In L. A. IVLIEV. Entomological researches in the Far East. Issue 2. Diptera of the Far East. Trudy Biologo-poch-vennogo Instituta, Dal'nevostochnyi Nauchnyi Tsentr, Akademiya Nauk S.S.S.R., 5, 192 p. (in russian).

Clausen C. P., 1978. Introduced parasites and predators of Arthropod pests and weeds. U.S.D.A. Agr. Handb., 480, Washington D.C., $545 \mathrm{p}$

Collyer E., 1967. On the ecology of Anthocoris nemorum (L.) (Hem. : Heteroptera). Proc. R. Entomol. Soc. Lond., (A), 42 (7-9), 107-118.

Constantinescu V., 1972. Factors limiting the multiplication of the grey cabbage aphid (Brevicoryne brassicae L.). Analele Inst. Cerc. Prot. Plant., 8, 103-110 (in rumanian).

Cranham J. E., 1980. Integrated pest control in orchards. Garden, $105(10), 406-409$.

D'Aguilar J., Pralavorio R., Rabasse J. M., Mouton R., 1977. Introduction en France du tigre du platane Corythuca ciliata (Say) (Het. : Tingidae). Bull. Soc, Entomol. Fr., 82 (1/2), 2-6.

Dean G. J., 1974. Effects of parasites and predators on the cereal aphids Metopolophium dirhodum WIk.) and Macrosiphum avenae (F.) (Hem. : Aphididae). Bull. Entomol. Res., 63 (3) 411-422.

Dean G. J., 1982. Phenology of aphidophagous predators. Ann. Appl. Biol., 101 (1), 182-184.

Delrio G., Ortu S., Prota R., 1981. Prospettive di lotta integrata nell'agrumicoltura sarda. Studi Sassaresi, 27, 205-232.

Delvare G., 1977. Etude de la reproduction et de la diapause de Prionomitus mitratus Dalm., Encyrtidae, parasite du psylle du poirier Psylla pyri (L.). Thèse, Toulouse, France, $76 \mathrm{p}$.

Delvare G., Mirkarimi A., Nguyen T. X., 1981. Redescription de Prionomitus mitratus Dalman (Hym. : Encyrtidae) endoparasite de psylles (Hom. : Psyllidae). Ann. Soc. Entomol. Fr., 17 (2), 171-178.

Dennis E. B., 1969. Control of euonymus scale. Plant Pathology, $18(2), 78-82$.

Dessart P., 1983. Dendrocerus psyllarum n. sp. (Hym. : Ceraphronoidea, Megaspilidae) parasite ou hyperparasite de psylles (Hom. . $\left.P_{s y l l i d a e}\right)$ en France et en Belgique. Bull. Ann. Soc. r. belge Entomol., 119, 222-226.

Dimitrov A., 1975. Forecasting of Thrips tabaci. Rast. Zashch., 23 (10), 19-22 (in bulgarian).

Dirimanov M., Dimitrov A., 1975. Role of useful insects in the control of Thrips tabaci Lind. and Myzodes persicae Sulz. on tobacco, p. 71-72. In : VIII International Plant Protection Congress, Mos cow 1975. Reports and informations. Section V. Biological and genetic control. Moscow, U.S.S.R., 225 p.
Dixon A. F. G., Barlow N. D., 1979. Population regulation in the lime aphid. Zool. J. Linnean Soc., 67 (3), 225-237.

Dixon A. F. G., Russel R. J., 1972. The effectiveness of Anthocoris nemorum and A. confusus (Hem. : Anthocoridae) as predators of the sycamore aphid Drepanosiphum platanoides. II. Searching behaviour and the incidence of predation in the field. Entomol. exp. appl., 15 (1), 35-50.

Du Merle P., 1983. Les facteurs de mortalité des cufs de Tortrix viridana L. (Lep.: Tortricidae). I. Le complexe des prédateurs (Hym. : Formicidae ; Derm. : Forficulidae; Orth. : Phaneropteridae; Neur. : Chrysopidae). Agronomie, 3 (3), 239-246.

Dusek J., Laska P., 1974. Overwintering and spring emergence of some common species of aphidophagous syrphids (Syrphidae). Folia Fac. Sci. Nat. Univ. Purkynianae Brunensis, 15 (1), 71-75.

Dyadechko N. P., 1967. Entomophagous insects and the causal agents of fungus diseases in phytophagous species of thrips. Zashch. Rast., 4, 149-151 (in russian).

Ekbom B. S., 1981. Efficiency of the predator Anthocoris nemortum (Het. : Anthocoridae) against the greenhouse whitefly Trialeurodes vaporariorum (Hom. : Aleurodidae). Z. Angew. Entomol., 92 (1), 26-34.

Elliot W. M., 1970. The action of some systemic aphicides on the nymphs of Anthocoris nemorum (L.) and A. contusum Reut. Ann. appl. Biol., 66 (2), 313-321.

Erkin E., 1983. Investigations on the hosts, distribution and efficiency of the natural enemies of the family Aphididae (Homoptera) harmful to pome and stone fruit trees in Izmir Province of Aegean Region. Türk. Bitki Koruma Dergisi, 7 (1), 29-49.

Estrada S. J., Carrillo S. J. L., 1971. Importancia de la fauna entomofaga del algodonero en la Comarca Lagunera. Agr. Tec. Mexico, 2 (12), 539-544.

Evans H. F., 1976a. The role of predator-prey size ratio in determining the efficiency of capture by Anthocoris nemorum and the scape reactions of its prey, Acyrtosiphon pisum. Ecol. Entomol., 1 (2), 85-90.

Evans H. F., 1976b. The effect of prey density and host plant characteristics on oviposition and the fertility in Anthocoris confusus (Reuter). Ecol. Entomol, 1 (3), 157-161.

Evans H. F., 1976c. The searching behaviour of Anthocoris confusus (Reuter) in relation to prey density and plant surface topography. Ecol. Entomol., 1 (3), 163-169.

Evans H. F., 1976d. Mutual interference between predatory anthocorids. Ecol. Entomol., 1 (4), 283-286.

Evans H. F., 1976e. The population dynamics of Anthocoris confusus in a laboratory ecosystem. J. Anim. Ecol., 45 (3), 773-789.

Fauvel G., 1974a. Les hétéroptères prédateurs en verger, p. 125-149. In : Les organismes auxiliaires en verger de pommiers, OILB/SROP, Groupe de travail pour la lutte intégrée en arboriculture, Broch. 3, 242 p.

Fauvel G., 1974b. Sur l'alimentation pollinique d'un anthocoride prédateur Orius (Heterorius) vicinus Rib. (Hémiptère). Ann. Zool. Ecol. Anim., 6 (2), 245-258.

Fauvel G., Atger P., 1981. Etude de l'évolution des insectes auxiliaires et de leurs relations avec le psylle du poirier (Psylla pyri L.) et l'acarien rouge (Panonychus ulmi Koch) dans deux vergers du Sud-Est de la France en 1979. Agronomie, 1 (9), 813-820.

Fauvel G., Grivaut G., 1976. Faut-il attribuer certains dégâts d'hétéroptères sur pommes à des Orius (Het. : Anthocoridae) ? Rev. Zool. Agr. Path. Vég., 75 (3), 81-92.

Fauvel G., Rambier A., Cotton D., 1978. Activité prédatrice et multiplication d'Orius (Heterorius) vicinus (Het. : Anthocoridae) in the galls of Eriophyes fraxinivorus (Acarina: Eryophyidae). Entomophaga, 23 (3), 261-270.

Fauvel G., Cotton D., Lefeuvre M., Lemoine J., 1980. La responsabilité des thrips dans la genèse des piqûres sur pommes. Arboriculture fruitière, 321, 40-42.

Fedosimov O. F., Tsedev D., 1970. The useful insects of Mongolia. Zashch. Rast., 15 (6), 51 (in russian).

Ferriere C., 1926. Un parasite de Psylla pyrisuga: Prionomitus mitratus Dalm. (Hym. : Encyrtidae). Ann. Soc. Entomol. Fr., 95 (2), 189-194.

Ferriere C., 1961. Encyrtides paléarctiques parasites des psylles. Entomophaga, 6 (1), 39-51. 
Fields C. J., Beirne B. P., 1973. Ecology of Anthocorid predators of the pear psylla in the Okanagan Valley, British Columbia. $J$. Entomol. Soc. Br. Columbia, 70 (1), 18-19.

Filippov N., 1982. Integrated control of pests of vegetable crops grown in the open in Moldavia. Acta Entomol. Fennica, 40, 6-9.

Frazer B. D., Nelson C., 1981. Note on the occurrence of predatory Anystis mites (Acari: Anystidae) in SW British Columbia. J. Entomol. Soc. Br. Columbia, 78, 46.

Fye R. E., 1981. Rearing and release of coccinellids for potential control of pear psylla. U.S.D.A., A.R.S., Adv. Agric. Tech., AAT$W-20,9 \mathrm{pp}$.

Garcia Mari F., Rivero J. M. Del, 1982. El acaro rojo Panonychus citri (McGregor), nueva plaga de los citricos en tspana. Bol. Serv. Def. Plagas Insp. Fitopatol., 7 (1/2), 65-77.

Gaudchau M., 1979. Vergleichende Untersuchungen zum Einfluss von Prädatoren auf die Populationsentwicklung der Erbsenblattlaus, Acyrthosiphon pisum (Harr.). Z. Angew. Entomol., 88 (5), 504-513.

Geoffrion R., 1981. Les psylles du poirier. Phytoma, 325, 5-6.

Georgala M. B., 1957. A contribution to the biology of the pear sucker Psylla pyricola. 44th Rep. E. Malling Res. Sta. 1955-1956, 135-141.

Gertsson C. A., 1980. The occurence of bugs in strawberry fields in southern Sweden. Entomol. Tids., 101 (2/3), $71-74$ (in swedish).

Giunchi P., 1980. Possibilities of biological control of pear insects, p. 48-49. In : Biological control in orchards, IOBC/WPRS Bull., III (6), $88 \mathrm{p}$.

Glen D. M., 1975. The effects of predators on the eggs of codling moth Cydia pomonella, in a cider-apple orchard in south-west England. Ann. Appl. Biol., 80 (1), 115-119.

Goksu M. E., Atak E. D., 1969. Investigations on the European red mite $(P . u l m i)$ in the region of Marmara and Thrace. Bitki Koruma Bült., 9 (1), 19-36.

Golfari L., 1937. Contributi a la conoscenza dell'entomofauna del pero (Pyrus communis L.). Bol. Istit. Entomol. Univ. Bologna, 9, 206-249.

Gollner-Scheiding U., 1978. Beitrag zur Kenntnis der Heteropterenfauna Mazedoniens. Acta Mus. Macedonici Sci. Nat., 15 (6), 145150

Golubenko N. N., 1969. A test of integrated control of the plum fruit moth Laspeyresia funebrana $\mathrm{Tr}$. (Lep. : Tortricidae). Ent. Obozr., 48 (3), 502-506 (in russian) ; Entomol. Rev., 48 (3), 318 321 .

Gomes A., 1980. Syrphids caught during the 2nd aphidological expedition to the Azores archipelago (Dipt. : Syrphidae). Bol. Soc. Port. Entomol., 9, 1-6 (in portuguese).

Goncharova N. G., 1968. Differentiated complex of control measures against the black-currant leaf gall midge. Izv. timiryazev. sel'. khoz. Akad., 1, 138-149 (in russian).

Goncharova N. G., Samosudov V. N., 1979. Protection of black currant from the leaf gall-midge. Zashch. Rast., 10, 38-39 (in russian).

Gourreau J. M., 1974. Systématique de la tribu des Scymnini (Coccinellidae). Ann. Zool. Ecol. anim., H.S., $211 \mathrm{p}$

Graham M. W. R. de V., 1969.The Pteromalidae of the North Western Europe (Hym. : Chalcidoidea). Bull. Brit. Mus. (Nat. Hist.), Entomol. Suppl. 16, London, $908 \mathrm{p}$

Grandi G., 1951. Introduzione allo studio dell'entomologia. Edizione Agricola Bologna, 1, 814-822.

Gravena S., 1979. Population dynamics of the greenbug, Schizaphis graminum (Rondani) (Hom. : Aphididae) and its natural enemies associated with grain sorghum in Jaboticabal, Sao Paulo, Brazil. Anais Soc. Entomol. Brasil, 8 (2), 325-334 (in portuguese).

Grigorov S., 1977a. Biological pecularities of some ladybird beetle species (Col. : Coccinellidae). Rast. Nauki, 14 (9), 133-142 (in bulgarian).

Grigorov S., 1977b. Study on the biology of the sugar beet roo aphid Pemphigus fuscicornis Koch (Hom.: Aphididae). Rast. Nauki, 14 (6), 120-128 (in bulgarian).

Grigorov S., 1978. A study of the biology of the peach aphid Myzus persicae'Sulz. (Hom. : Aphididae). Rast. Nauki, 15 (9/10), 184-193 (in bulgarian).
Grigorov S., 1983. Parasites and diseases of species of the family Coccinellidae. Rast. Nauki, 20 (2), 113-121 (in bulgarian).

Groh K., Tanke W., 1980. Untersuchungen zum Einfluss von Herbizidapplikationen aud die Fauna in Zuckerrüben-Anbauflächen, p. 493-497. In : Russ K. \& Berger H. edit., Proceedings International symposium of IOBC/WPRS on integrated control in agriculture and forestry, Vienna, 8th-2Ith Oct. 1979. Vienna, Austria., 393605 .

Gumovskaya G. N., 1982. The role of ladybirds in the suppression of the beet aphid. Zashch. Rast., 5, 29-30 (in russian).

Habib A., Rezk G. N., Farghaly H. T., Ragab Z. A., 1980. Seasonal abundance of some predators in cotton fields and its relation to certain pests. Bull. Entomol. Soc. Egypt., 60, 191-196.

Hafez M., Khalil F. M., Abd-El-Kawi A., 1975. Survey of predators occuring in clover and cotton fields at Assiut locality. Agr. Res. Rev., 53 (1), 43-45.

Hafez M., Tawfik M. F. S., Awadallah K. T., Sarham A. A., 1983. Natural enemies of the cotton whitefly, Bemisia tabaci (Gienn.), in the world and in Egypt. Bull. Soc. Entomol. Egypte, 62, 9-13.

Hagley E. A. C., Simpson C. M., 1983. Effect of insecticides on predators of the pear psylla Psylla pyricola (Hem. : Psyllidae), in Ontario. Can. Entomol., 115, 1409-1414.

Hamid S., Shah M. A., Anwar A. M., 1977. Some ecological and behavioural studies on Aphis craccivora Koch (Hem. : Aphididae). Tech. Bull. Commonwealth Inst. Biol. Contr., 18, 99-111.

Hamilton P. A., 1973. The biology of Aphelinus flavus (Hym. : Aphelinidae), a parasite of the sycamore aphid Drepanosiphum platanoides (Hem. : Aphididae). Entomophaga, 18 (4), 449-462.

Hassanein M. H., Afify A. M., Farghaly H. T., 1968. Daily and seasonal density of four entomophagous predators on cotton in Upper Egypt. Entomophaga, 13 (2), 143-150.

Hayat M., 1981. Taxonomic notes on Indian Encyrtidae (Hym. : Chalcidoidea), III. Colemania, 1 (1), 13-14.

Heathcote G. D., 1978. Coccinellid beetles on sugar beet in eastern England, 1961-1975. Plant Pathology, 27 (3), 103-109.

Hellen W., 1949. Zur Kenntnis der Encyrtiden Finnlands. Notulae Entomol., 29, 41-50.

Hellpap C., 1982. Untersuchungen zur Wirkung verschiedener Insektizide auf Prädatoren von Getreideblattläusen unter Freilandbedingungen. Anz. Schädl. Pflanz. Umw., 55 (9), 129-131.

Henry T. J., 1977. Orthotylus nassatus, a european plant bug new to North America (Het. : Miridae). Coop. Plant Pest Rep., 2 (31), 605-608.

Henry T. J., Wheeler A. G. Jr., 1979. Paleartic Miridae in North America : records of newly discovered and little-known species (Hem. : Heteroptera). Proc. Entomol. Soc. Washington, 81 (2), 257-268.

Herard F., 1985. Analysis of parasite and predator populations observed in pear orchards infested by Psylla pyri (L.) (Hom. Psyllidae) in France. Agronomie, 5 (9), 773-778.

Herard F., Chen K., 1985. Ecology of Anthocoris nemorum (L.) (Het. : Anthocoridae) and evaluation of its potential effectiveness for biological control of pear psylla. Agronomie, 5 (10), 855-864.

Hill A. R., 1957. The biology of Anthocoris nemorum in Scotland (Hem. : Anthocoridae). Trans. R. entomol. Soc. Lond., 109 (13), 379-394.

Hodkinson I. D., Flint P. W. H., 1971. Some predators from the galls of Psyllopsis fraxini L. (Hem. : Psyllidae). Entomol. Mon. Mag., 107 (1280/1282), 11-12.

Holdsworth R. P. Jr., 1970a. Codling moth as part of an integrated program in Ohio. J. econ. Entomol., 63 (3), 894-897.

Holdsworth R. P. Jr., 1970 b. Aphids and aphid enemies : effect of integrated control in an Ohio apple orchard. J. econ. Entomol., 63 (2), 530-535.

Honek A., 1978. Les facteurs qui déterminent la composition de l'ensemble des adultes de Coccinellidae et Chrysopidae sur trois espèces de mauvaises herbes, p. 357-358. In: Colloque FrancoTchécoslovaque sur la "Spécificité » des entomophages" (C.R. Antibes), 26 Sept.-Ier Oct. 1977, I.N.R.A. Ann. Zool. Ecol. Anim., 10 (3), 357-358.

Honek A., 1982. Factors which determine the composition of field communities of adult aphidophagous Coccinellidae (Coleoptera). $Z$. Angew. Entomol., 94 (2), 157-168. 
I.O.B.C., 1980. Biological control in orchards. Biology and control of codling moth. Wye (U.K.), 25-29 March 1980. Bull. SROP, 3 (6), $88 \mathrm{p}$.

Iperti G., 1974. Les coccinelles, p. 111-121. In : Les organismes auxiliaires en verger de pommiers, OILB/SROP, Broch. 3, $242 \mathrm{p}$. Iperti G., 1978a. Comportement alimentaire des coccinelles, p. 406406. In: Colloque Franco-Tchécoslovaque sur la Spécificité des entomophages (C.R. Antibes) (26 Sept. au Ier Oct. 1977) (I.N.R.A.). Ann. Zool. Ecol. Anim., 10 (3), 315-459.

Iperti G., 1978b. Coïncidence spatiale des coccinelles et des pucerons, p. 373-375. In: Colloque Franco-Tchécoslovaque sur la «Spécificité des entomophages" (C.R. Antibes) (26 Sept. au

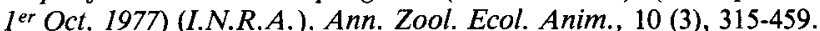

Ishankulieva T., 1979. The use of larvae of the common lacewing in the control of pests of cotton. Izv. Akad. Nauk Turkmenskoi S.S.R., Biol. Nauk, 1, 17-21 (in russian).

Ismail I. I., Swailem S. M., 1976. On the biology of the bollworm Heliothis armigera (Hubner) (Lep. : Noctuidae). Bull. Soc. Entomol. Egypte, 59, 207-216.

Ito K., Iwao S., 1977. Oviposition behavior of a syrphid, Episyrphus balteatus in relation to aphid density on the plant. Jap. J. Appl. Entomol. Zool., 21 (3), 130-134 (in japanese).

Ivanov S., 1978. A system for the control of leafmining moths on fruit trees. Rast. Zashch., 26 (4), 2-4 (in bulgarian).

Jackson H. B., Coles L. W., Wood Jr. E. A., Eikenbary R. D., 1970. Parasites reared from the greenbug and corn leaf aphid in Oklahoma in 1968 and 1969. J. econ. Entomol., 63 (3), 733-736.

Janiszewska-Cichocka E., 1971. The biology of the currant root aphid Eriosoma ulmi L. (Hom. : Aphidoidea). Rocz. Nauk Rolniczych, Ser. E, 1 (2), 25-55 (in polish).

Jasiolek Z., Kania C., Sobota G., 1974. Hover-flies (Dipt. : Syrphidae) destroying aphids on maize. Polskie Pismo Entomol., 44 (2), 425-430.

Jensen D. D., 1957. Parasites of the Psyllidae. Hilgardia, 27 (2), 71 99.

Jones M. G., 1969. The effect of weather on frit fly (Oscinella frit L.) and its predators. J. appl. Ecol., 6 (3), 425-441.

Jones M. G., 1979. Abundance of aphids on cereals from before 1973 to 1977. J. Appl. Ecol., 16 (1), 1-22.

Jubb G. L. Jr., Masteller E. C., 1977. Survey of arthropods in grape vineyards of Erie County, Pennsylvania : Neuroptera. Environ. Entomol., 6 (3), 419-428.

Kaczmarek S., 1973. Studies on the aphidophagous Coccinellidae of cultivated fields in the Koszalin administrative district. Ekologia Polska, 21 (26), 377-403.

Kania C., El-Fayoumi M., Kelm M., Koroluk L., 1976. Heteroptera in a potato agrocoenosis in Pawlowice Wielkie near Wroclaw in 1971-1974. Polskie Pismo Entomol., 46 (3), 595-605 (in polish).

Kanterina N. F., 1974. Beneficial insects in sowings of leguminous crops. Zashch. Rast., 2, 23 (in russian).

Karadzhov S., 1973a. The problem of harmful Acarina on apple. Rast. Zashch., 21 (11), 21-26 (in bulgarian).

Karadzhov S., 1973b. Dynamics of the phytophagous and predacious mites in a biological system of pest control on apple. Grad. Loz. Nauka, 10 (5), 51-62 (in bulgarian).

Karelin V. D., 1980. Conditions for the use of syrphids. Zashch. Rast., 11, 40-41 (in russian).

Kartasheva T. T., Lesteva E. E., 1979. The role of acarophages in the regulation of numbers of fruit spider mites in orchards in Kirgizia. Entomol. Issled. Kirgizii, 13, 82-85 (in russian).

Keimer C., 1983. La protection intégrée contre le spylle du poirier, exemple d'application pratique de la recherche entomologique. Mitt. Schw. Entomol. Ges., 56 (1-2), 182.

Kelton L. A., 1978. The insects and arachnids of Canada. Part 4. The Anthocoridae of Canada and Alaska (Het. : Anthocoridae). Canada Dept. Agr., Ottawa, Canada, 101 p.

Kelton L. A., 1982. New records of European Pilophorus and Orthotylus in Canada (Het. : Miridae). Can. Entomol. 114 (3), 283287

Kesten L. A., 1975. Insect enemies of the lucerne aphid. Zashch. Rast., 11, 28 (in russian)
Kfir R., Rosen D., 1981. Biology of the hyperparasite Pachyneuron concolor (Forster) (Hym. : Pteromalidae) reared on Microterys flavus (Howard) in brown soft scale. J. Entomol. Soc. South Africa, 44 (1) $151-163$.

Khalil F. M., Awadallah K. T., Mahmoud T. T., 1979. Seasonal abundance of natural enemies associated with alfalfa plants in Hamman Al-Alil. Deutsche Entomol. Z., 26 (4/5), 181-186.

Khan S., Yunus M., 1970. Biology of Syrphus balteatus DeGeer. Pakistan J. Zool., 2 (2), 215-217.

Kim H. S., Moon D. Y., Lippold P. C., Chang Y. D., Park J. S., 1978. Studies on the integrated control of citrus pests. I. Bionomics of citrus red mite and natural enemies. Korean J. Plant Prot., 17 (1), 7-13.

Kismir A., Sengonca C., 1981. Studies on the development of methods of mass-rearing Anisochrysa carnea (Neur. : Chrysopidae). Türkiye Bitki Koruma Dergisi, 5 (1) 35-41 (in turkish).

Knapen H., Vanwetswinkel G., 1977. Pear psylla (Psylla pyri) biology and control, p. 1315-1322. In : XXIX International Symposium on Phytopharmacy and Phytiatry, 1977. Mededelingen van de Faculteit Landbouwwetenschappen Rijksuniversiteit Gent, 42 (2, I ; 2, II), VII + 819-1290; VI + 1261-1847.

Koehler W., 1967. Considerations for the discussion on the use of Trichogramma sp. (Hym. : Chalcidoidea) in the biological method of forest protection, p. 587-596. In : IUFRO-Kongress, München 1967. Referate-Papers-Exposés. V. Section 24, ix $+888 \mathrm{p}$.

Konovalova Z. A., 1978. New and little-known species of psyllids (Hom : Psylloidea) of the Far East, p. 24-30. In : Krivolutskaya G. O. (edit.), New data on the insects of Sakhalin and the Kuril Islands. Trud. Biol.-pochv. Inst., Nov. Ser., 50 (153), 168 p. (in russian). Korcz A., 1967. The predator bug fauna on apple trees in the vicinity of Poznan. Polskie Pismo entomol., 37 (3), 581-586.

Korcz A., 1971. Predacious bugs of the order Heteroptera in orchards and their role in the control of mites (Tetranychidae). Prace Nauk. Inst. Ochr. Roslin, 12 (2), 3-77 (in polish).

Koval Y. V., 1968. Predators of the Colorado potato beetle. Zashch. Rast., 13 (4), 52 (in russian).

Kozlowska A., 1978. Hover flies (Dipt. : Syrphidae) feeding on aphids associated with fruit trees and berry shrubs in the environs of Lublin, Poland. Polskie Pismo Entomol., 48 (4), 677-686 (in polish).

Krombein K. V., Hurd P. D. Jr., Smith D. R., Burks B. D., 1979. Symphyta and Apocrita (Parasitica). In : Catalog of Hymenoptera in America North of Mexico, 1, 1198 p., Smithsonian Institution Press, Washington D. C.

Kula E., 1982. The syrphid flies (Dipt. : Syrphidae) of spruce forest. Folia Fac. Sci. Nat. Univ. Purkynianae Brunensis, Biol., 23 (7), 61-64.

Kunovski Z., 1969. The 22-spotted lemon-coloured ladybird. Rast. Zasch., 17 (11), 13-16 (in bulgarian).

Laffi F., 1982. Il ragnetto giallo della vite. Eotetranychus carpini Oud. f. vitis Dosse. Inf. Fitopatol., 32 (6), 31-34.

Lakhidov A. I., 1970. Aphidophagous Coccinellids on Leguminosae. Zashch. Rast., 15 (11), 48-49 (in russian).

Lal K. B., 1934. Insect parasites of Psyllidae. Parasitology, 26 (3), 325-334

Laska P., 1967. The effects of isolation cages on the injuriousness of the cabbage aphid (B. brassicae) to cabbage. Bull. vyzk. Ust. zelin. Olomouc, 11, 66-75.

Latteur G., 1973. Etude de la dynamique des populations des pucerons des céréales. Premières données relatives aux organismes aphidiphages en trois localités différentes. Parasitica, 29 (3), 134-151.

Lauenstein G., 1976. Untersuchungen zu Biologie und Verhaltensweisen der räuberischen Blumenwanze Anthocoris nemorum L. (Het. : Anthocoridae). Diss. Univ., Göttingen.

Lauenstein G., 1977. Untersuchungen zu Fruchtbarkeit und Eiablage der räuberischen Blumenwanze Anthocoris nemorum L. (Hem. : Heteroptera). Z. Angew. Entomol., 83 (4), 355-363.

Lauenstein G., 1980. Zum Suchverhalten von Anthocoris nemorum L. (Het. : Anthocoridae), Z. Angew. Entomol., 89 (5), 428-442.

Lauterer P., 1982. New data on the occurence, bionomics and taxo- 
nomy of some Czechoslovakian Psylloidea (Homoptera). Casopis Moravskeko Musea, Vedy Prirodni, 67, 133-162.

Lee P. P., Hsu T. C., 1979. Some additions to the aphid fauna of Taiwan. NTU Phytopathologist and Entomologist, 6, 23-37.

Liotta G., 1981. Osservazioni bio-etologiche su Clitostethus arcuatus (Rossi) (Col. : Coccinellidae) in Sicilia. Redia, 64, 173-185.

Liotta G., 1982. La mosca bianca fioccosa degli agrumi. Inf. Fitopatol., 32 (12), 11-15.

Liotta G., Maniglia G., 1975. Action des huiles blanches contre les stades hivernants de Dialeurodes citri (Ashm.) (Hom. : Aleurodidae) sur citronnier, p. 323-327. In : XXVII International Symposium on Phytopharmacy and Phytiatry, 1975. Mededelingen van de Faculteit Landbouwwetenschapen Rijksuniversiteit Gent, 40 (2, I ; 2, II), $(12+)$ 203-705; $(6+) 751-1247$.

Lipa E. Y., Sem'yanov V. P., 1967. Parasites of coccinellids (Col. : Coccinellidae) in the Leningrad region. Entomol. Obozr., 46 (1), 75-80 (in russian).

Livshits I. Z., Mitrofanov V. I., 1981a. Beneficial insects and mites in fruit orchards. Zashch. Rast., 6, 49-52 (in russian).

Livshits I. Z., Mitrofanov V. I., 1981b. Beneficial insects and mites in fruit orchards. Zashch. Rast., 9, 56-58 (in russian).

Loi G., 1979. Osservazioni eco-etologiche sul coleottero coccinellide scimnino Clitostethus arcuatus (Rossi), predatore di Dialeurodes citri (Ashm.) in Toscana. Frustula Entomol., 1, 123-125.

Lord F. T., 1968. Influence of the proportion of fruiting to nonfruiting clusters on the distribution of insect predators on apple trees. Can. Entomol., 100 (3), 308-312.

Lord F. T., 1971. Laboratory tests to compare the predatory value of six Mirid species in each stage of development against the winter eggs of the European red mite, Panonychus ulmi (Acari : Tetranychidae). Can. Entomol., 103 (12), 1663-1669.

Lovei G. L., 1981. Coccinellid community in an apple orchard bordering a deciduous forest. Acta Phytopathol. Acad. Sci. Hungaricae, $16(1 / 2), 143-150$.

Lyashova L. V., 1981. The 14-spotted propylea. Zashch. Rast., 11, 29-30 (in russian).

Lyon J. P., 1971. Les syrphides (Diptères) prédateurs des pucerons de la betterave. Parasitica, 27 (4), 103-111.

Lyon J. P., GMldlin de Tiefenau P., 1974. Les Syrphes prédateurs de pucerons, p. 163-170. In: Les organismes auxiliaires en verger de pommiers, OILB/SROP, broch. 3, $242 \mathrm{p}$.

Mack T. P., Smilowitz Z., 1979. Diel activity of green peach aphid predators as indexed by sticky traps. Environ. Entomol., 8 (5), 799 801.

Magalhâes G. S., 1980. Note in the introduction of Aleurothrixus floccosus (Mask.) (Hom. : Aleurodidae) in south Portugal and its control by Cales noacki How. (Hym. : Aphelinidae), p. 572-573. In: Russ K., Berger H., (edit.), Proceedings International Symposium of IOBC/WPRS on integrated control in agriculture and forestry. Vienna, 8th-12th Oct. 1979, 393-605.

Maher-Ali A., Moftah S. A., Rizk G. A., 1983. Evaluation of the impact of certain predators on the population density of egg-masses of the cotton leafworm, Spodoptera littoralis (Boisd.) in cotton fields. Bull. Soc. Entomol. Egypte, 62, 111-116.

Mahmoud T. T., Khalil F. M., Awadalla K. T., 1981. Population dynamics of aphids and enemies on peach trees in Mosul region, Iraq. Mesopotamia J. Agric., 16 (2), 167-183.

Marboutie G., 1976. Premiers résultats d'essais de lutte biologique en vergers de pêchers et de pommiers. Rev. Zool. Agric. Pathol. Vég., 75 (1), 23-30.

Matta V. A., 1979. Enemigos naturales de las conchuelas blancas del olivo en el valle de Azapa, Arica-Chile. Idesia, 5, 231-242.

McMullen R. D., Jong C., 1967a. The influence of three insecticides on predation of the pear psylla, Psylla pyricola. Can. Entomol., 99 (12), 1292-1297.

McMullen R. D., Jong C., 1967b. New records and discussion of predators of the pear psylla, Psylla pyricola Forster, in British Columbia. J. Entomol. Soc. Br. Columbia, 64, 35-40.

Mentzelos I. A., 1967. Contribution to the study of the entomophagous insects of Siphonınus phillyreae Halid. (= inaequalis Gautier) (Aleurodidae) on pear trees in central Macedonia. Rep. Pl. Prot. agric. Res. Stn Thessalonoki, 3, 92-102 (in greek).
Meszleny A., Szalay-Marzso L., 1979. Data on aphids (Hom. : Aphidina) in apple orchard with particular emphasis on their fight dynamics and natural control factors (Studies in apple ecosystems N. 6). Acta Phytopathol. Acad. Sci. Hungaricae, 14 (3/4), 465-479. Mills N. J., 1979. Adelia bipunctata (L.) as a generalist predator of aphids. Thesis, East Anglia University, Norwich, UK., 91 p.

Mills N. J., 1982. Voracity, cannibalism and coccinellid predation. Ann. Appl. Biol., 101 (1), 144-148.

Milne D. L., 1977. Biological control of citrus thrips, Scirtothrips aurantii: what are the prospects? Citrus and Subtropical Fruit Journal, 528, 14-16.

Missonnier J., 1971. Role des ennemis naturels de la pégomyie de la betterave en France. Parasitica, 27 (4), 112-114.

Mitic-Muzina N., 1967. The parasites of the spherical scale (Eulecanium prunastri). Zast. Bilja, 18 (93-95), 183-187.

Molchanov R. V., 1981. Entomological complexes of the undergrowth and saplings of pine forests of Byelorussia. Trudy Vsesoyuznogo Entomol. Obsh., 63, 14-16 (in russian).

Monaco R., 1976. Nota su Metaphycus lounsburyi (How.) (Hym. Encyrtidae) parassita di Saissetia oleae (Uliv.). Entomologica, 12, 143-151.

Monaco R., 1977. Note bio-ecologiche sulla Trabutina leonardii Silv. (Hom. : Coccidae) e suoi predatori. Entomologica, 13, 155163.

Moreau J. P. H., 1983. Aphid pullulations in maize crops : damage induced natural control by antagonists. In : Aphid antagonists. Proceedings of a meeting of the EC Experts' Group, Portici, Italy, 23-24 Nov. 1982 (ed. Cavalloro R.). Rotterdam, Netherlands: A. A. Balkema, 93-99.

Mori P., Vianello G., 1980. Integrated control of Carpocapsa pomonella L. with diflubenzuron (test results), p. 455-457. In : Russ K., Berger H. (edit.), Workshop sessions, Proceedings. International symposium of IOBC/WPRS on integrated control in agriculture and forestry. Vienna, 8th-12th oct. 1979, 393-605.

Morris M. G., 1968. The effect of sprays on the fauna of apple trees. V. DDT/BHC and lead arsenate/nicotine applied at the green cluster stage. J. appl. Ecol., 5 (2) 409-429.

Mostaan M., Seyedoleslami H., Farivar-Mahin G., Farahbakhch G., Daftari K., 1972. Complementary study of the biology and methods of control of Lepidosaphes malicola Borkh. in Iran. Entomol. Phytopathol. Appl., 33, 4-20 (in iranian).

Murashevskaya Z. S., 1969. Species of Chilocorus. Zashch. Rast., 14 (11), 36-38 (in russian).

Myrzin A. S., Luk'yanchikov V. P., 1981. Aphid enemies on rice. Zashch. Rast., 11, 44 (in russian).

Narzikulov M. N., Umarov S. A., 1975. The theory and practice of integrated control of cotton pests. Entomol. Obozr., 54 (1), 3-16 (in russian).

Natskova V., 1971. The parasites and predators of aphids on roses. Rast. Zashch., 19 (11), 19-22 (in bulgarian).

Natskova V., 1973. The effect of aphid predators on the abundance of aphids on peppers. Rast. Zashch., 21 (1), 20-22 (in bulgarian).

Natskova V., 1977. Natural enemies of aphids on vegetable crops. Rast. Zashch., 25 (2), 7-10.

Nguyen T. X., Delvare G., 1984. Biocoenose des psylles du poirier (Psylla pyri L. et Psylla pyrisuga Foerster) dans la région toulousaine, France, p. 191-197. In: Colloque international sur la lutte incegrée contre les psylles du poirier. Toulouse, 27-29 sept. 1983, Bull. OILB/SROP, VII (5), 388 p.

Nguyen T. X., Bouyjou B., Delvare G., 198 . Les psylles du poirier et leur complexe parasitaire. La défense des végétaux, 209, 221-226.

Nickel J. L., Shimizu J. T., Wong T. T. Y., 1965. Studies in natural control of pear psylla in California. J. econ. Entomol., 58 (5), 970-976.

Niemczyk E., 1967. Psallus ambiguus (Fall.) (Het.: Miridae). Part I. Morphology and biology. Polskie Pismo entomol., 37 (4), 797-842.

Niemczyk E., 1968. Psallus ambiguus (Fall.) (Heteroptera, Miridae). Part II. Its nutrition and role in orchard biocoenoses. Polskie Pismo entomol., 38 (2), 387-416 (in polish).

Niemczyk E., 1969. The occurence of Heteroptera in sprayed and 
unsprayed apple orchards. Prace Inst. Sadow. Skiern., 12, 355-363 (in polish).

Niemczyk E., 1970. The development and fecundity of the bark bug Anthocoris nemorum (L.) (Het. Anthocoridae) reared on the eggs of the Angoumois grain moth Sitotroga cerealella Oliv. (Lep. : Gelechiidae). Polskie Pismo Entomol., 40 (4), 857-865.

Niemczyck E., 1978a. Food requirement searching abilities and role of Orius minutus L. (Het. Anthocoridae) in controlling the twospotted mite Tetranychus urticae Koch. Polskie Pismo Entomol., 48 (3), 445-451.

Niemczyk E., 1978b. Orius minutus (L.) (Het. : Anthocoridae) : the occurence in apple orchards, biology and effect of different food on the development. Polskie Pismo Entomol., 48 (2), 203-209.

Niemczyk E., 1978c. The role of Orius minutus (L.) in controlling the European mite Panonychus ulmi Koch on young apple trees. Polskie Pismo Entomol., 48 (2), 211-229.

Niemezyk E., Miszczak M., Nowakowski Z., 1972. The influence of pesticides on some predacious insects. In: Wegorek $W$. (edit.), Papers presented at the 12th Scientific Session of the Institute for Plant Protection 3rd-5th Feb. 1972. Biul. Inst. Ochr. Roslin, 52, 556 p. (in polish).

Nordlander G., 1977. Observations on the insect fauna in apple trees in connection with tests on insecticides for integrated control. Wäxtskyddsnotiser, 41 (2), 39-48 (in swedish).

Notario A., Castresana Estrada L., Iglesias Gonzalez L., 1978. Contribucion al estudio biologico de Coccinella septempunctata $\mathrm{L}$. (Col. : Coccinellidae). An. Inst. Nac. Invest. Agrar., Prot. Veg., 8, 65-77.

Novokhatka V. G., Krivovyaz I. Z., Dubovoi V. I., 1980. Towards control of the cereal aphid. Zashch. Rast., 10, 41 (in russian).

Obrycki J. J., Nechols J. R., Tauber M. J., 1982. Establishment of European lady beetle in New York State. New York's Food and Life Sci. Bull., 94, 4 p.

Onder F., 1982. The turkish fauna of Anthocoridae (Heteroptera) : Taxonomic and faunistic studies. Ege Univ. Ziraat Fak. Yayinlari, 459,159 p. (in turkish).

Ongoren K., Kaya N., Turkmen S., 1975. Investigations on the identification of the species of red spider-mites injurious to vegetables in the Aegean region, and on the biology, control measures and natural enemies of the most widely distributed species, the twospotted spider-mite Tetranychus urticae (Koch). Bitki Koruma Bül., 15 (1), 3-29 (in turkish).

Overmeer W. P. J., 1961. Investigations on species of pear psyllids in the Netherlands. Tijdschr. Plziekt., 67 (4), 281-289.

Palaniswami M. S., Pillai K. S., 1980. Parasites on Aphis gossypii G. infesting taro and tannia. Current Science, 49 (21), 830.

Panis A., 1980. Dégâts de Coccidae et Pseudococcidae (Hom. : Coccoidea) citrus en France et effets particuliers de quelques pesticides sur l'entomocénose du verger. Fruits, 35 (12), 779-782.

Pantyukhov G. A., 1968. On the photoperiodic reaction of Chilocorus renipustulatus Scriba (Col. : Coccinellidae). Entomol. Obozr., 47 (1), $45-50$ (in russian). Entomol. Rev., 47 (1), 26-29.

Papaioannou-Soulioti P., 1980. A simple technique for breeding Panonychus ulmi (Koch) (Acarina: Tetranychidae). Ann. Inst. Phytopathol. Benaki, 12 (2), 179-182.

Parker N. J. B., 1975. An investigation of reproductive diapause in two British populations of Anthocoris nemorum (Hem. : Anthocoridae). J. Entomol. (A), 49 (2), 173-178.

Parker N. J. B., 1981. A method of mass rearing the aphid predator Anthocoris nemorum. Ann. Appl. Biol., 99 (3), 217-223.

Pasqualini E., 1979. Evoluzione delle popolazioni di Panonychus ulmi Koch (Acarina : Tetranychidae) e del suo predatore Stethorus punctillum Weise (Col. : Coccinellidae) su melo. Boll. Ist. Entomol. Univ. St. Bologna, 34, 1-14.

Pasqualini E., Briolini G., Memmi M., 1982. Indagini preliminari sul danno da Panonychus ulmi Koch (Acarina: Tetranychidae) su melo in Emilia Romagna. Boll. Ist. Entomol. Univ. St. Bologna, $36,173-190$.

Pass B. C., Parr J. C., 1971. Seasonal occurence of the pea aphid and a Braconid parasite Aphidius smithi in Kentucky. J. econ. Entomol., 64 (5), 1150-1153.

Patnaik N. C., Satpathy J. M., Bhagat K. C., 1977. Note on the occurence of aphidophagous insect predators in Puri district
(Orissa) and their predation on the sorghum aphid Longiunguis sacchari (Zhnt.). Indian J. Agric. Sci., 47 (11), 585-586.

Pauriene P., 1970. Predacious mites on orchards plants in the Lithuanian SSR. Acta Entomol. Lituanica, 1, 178-179 (in russian).

Pek L. V., 1975. Predacious hoverflies of Kirgizia (Dipt. : Syrphidae), p. 79-82. In Protsenko A. I. (edit.), Entomological investigations in Kirgizia. Vol. 10. Izdatel'stvo " Ilim », 136 p. (in russian).

Pelov V., Trenchev G., 1973. The pear whitefly and its natural enemies. Rast. Zashch., 21 (11), 26-27 (in bulgarian).

Pericart J., 1972. Hémiptères, Anthocoridae, Cimicidae et Microphysidae de l'Ouest-Paléarctique. Faune de l'Europe et du Bassin méditerranéen, 7, 402 p., Masson \& Cie éd., Paris.

Pezzi A., 1982. Osservazioni sulle fluttuazioni delle popolazioni della Psylla pyri e del suo predatore Anthocoris nemoralis (F.). Inf. fitopatol., 32 (3), 51-53.

Philogene B. J. R., Chang J. F., 1978. New records of parasitic chalcidoids of pear psylla (Hom. : Psyllidae) in Ontario, with observations on the current world status of its parasitoids and predators. Proc. Entomol. Soc. Ontario, 53-60.

Picco D., Picco A. M., 1978. Even the pear psylla (Psylla pyri L.) can be placed under control by its natural biotic enemy complex, in the protection of Pomaceae by " complementary control ». Not. Mal. Piante, 98/99, 101-117.

Plugaru S. G., 1969. On the biology of the oak leaf-beetle in Moldavia. Vred. polez. Fauna Bespozyon. Moldavii, 4/5, 56-64 (in russian).

Podsiadlo E., 1981. Parasitic wasps (Hym. : Chalcidoidea) reared from females of the globose scale Sphaerolecanium prunastri (Fonscolombe) in Warsaw (Hom. Coccidae). Polskie Pismo Entomol., 51 (1), 153-158 (in polish).

Pollard E., 1969. The effect of removal of arthropod predators on an infestation of Brevicoryne brassicae (Hem. : Aphididae) on brussels sprouts. Entomol. exp. appl., 12 (1), 118-124.

Popova A. 1., 1971. Chilocorus in the control of the California scale. Zasch. Rast., 16 (12), $42-43$ (in russian).

Popova A. I., 1974. Parasites of the males of the California scale. Zasch. Rast., 3, 56 (in russian).

Principi M. M., Canard M., 1974. Les Névroptères, p. 151-162. In : Les organismes auxiliaires en verger de pommiers. OILB/SROP, broch. 3, 242 p.

Priore R., 1969. Il Dialeurodes citri (Ashmead) (Hom. Aleyrodidae) in Campania. (Note di morfologia e biologia). Boll. Lab. Entomol. Agrar. Filippo Silvestri, Portici, 27, 287-316.

Pruszynski S., Lipa J. J., 1971. The occurence of predatory Coccinellidae on alfalfa crops. Ekologia Polska, 19 (26), 365-386.

Puchkov A. V., 1980. Particulars of the biology of predacious Nabis spp. Zashch. Rast., 8, 44 (in russian).

Pukinskaya G. A., Solov'eva O. M., Didenko I. V., 1981. Aphidophagous insects and the numbers of ceral aphids. Zashch. Rast., 9, 25 (in russian).

Radev R., 1968. Studies on the bioecology of the cotton leaf aphid Aphis gossypii Glov. (Hom. : Aphididae) on cotton. Rast. Nauki, 5 (10), 109-131 (in bulgarian).

Radke S. G., Barwad W. L., 1978. New record of parasite Aphidencyrtus aphidivorus (Mayr) (Hym. : Encyrtidae) on Rhopalosiphum maidis (Fitch) and the efficacy of the various insecticides on the host and effect on parasitism. Indian J. Entomol., 40 (1), 59-62. 62.

Radwan Z., Lovei G. L., 1982. Distribution and bionomics of ladybird beetles (Col. Coccinellidae) living in an apple orchard near Budapest, Hungary. Z. Angew. Entomol., 94 (2), 169-175.

Radzivilovskaya M. A., 1980. The chrysopid against aphids on cotton. Zashch. Rast., 10, 26 (in russian).

Ramakers P. M. J., 1978. Possibilities for biological control of Thrips tabaci Lind (Thysanoptera: Thripidae) in glasshouses, p. 463-469. In : XXX International Symposium on crop protection. Mededelingen van de Faculteit Landbouwwetenschapen Rijksuniversiteit Gent, 43 (2, I ; 2, II), ix + 351-908; iii + 909-1322.

Rao V., Ghani M. A., 1972. Studies on predators of Adelges spp. in the Himalayas. Misc. publ. Commonwealth Inst. Biol. Control, Trinidad, 3, $116 \mathrm{p}$.

Rautapaa J., 1977. Evaluation of predator-prey ratio using 
Chrysopa carnea Stephens in control of Rhopalosiphum padi (L.). Ann. Agric. Fenniae, 16, 103-109.

Remaudiere G., Leclant F., 1971. Le complexe des ennemis naturels des aphides du pêcher dans la moyenne vallée du Rhône. Entomophaga, 16 (3), 255-267.

Rezk G. N., Iss-Hak R. R., Ragab Z., 1975. Competition between three different species of predator insects and their effect on the population density of Aphis gossypii Glov., in cotton fields. $Z$. Angew. Entomol., 78 (2), 181-185.

Rosen D., Kfir R., 1983. A hyperparasite of coccids develops as a primary parasite of fly puparia. Entomophaga, 28 (1), 83-87.

Roy P., Basu S. K., 1978. Bionomics of aphidophagous syrphid flies. Indian J. Entomol., 39 (2), 165-174.

Ruschka F., 1923. Beitrage zur Kenntnis eineger Encyrtidengattunge (Hym. : Chalcidoidea). Verh. Zool. Bot. Ges. Wien, 72, 13.

Russel R. J., 1970. The effectiveness of Anthocoris nemorum and A. confusus (Hem. : Anthocoridae) as predators of the sycamore aphid. Drepanosiphum platanoides. I. The number of aphids consumed during development. Entomol. exp. \& appl., 13, 194-207.

Russel R. J., 1972. Defensive responses of the aphid Drepanosiphum platanoides in encounters with the bug Anthocoris nemorum. Oikos, 23, 264-267.

Rustamova M. R., 1981. Entomophagous insects on cotton. Zashch. Rast., 3, 36 (in russian).

Rybchin V. E., 1982. Enemies of root-nodule weevils. Zasch. Rast., 2, 30-31 (in russian).

Saddik A., El-Miniawi S. F., 1978. A study on infestation of artichoke Cynara cardunculus v. scolvmus L. by looper caterpillars and other pests, p. 179-187. In : Proceedings of the Fourth Conference of Pest Control, Sept. 30-Oct. 3, 1978 (Part 1), $(2+)$ vii +677 p.

Santas L. A., 1979. Distribution of aphids of citrus and cotton and their parasites in Greece. Biol. Gallo-Hellenica, 9, 315-319.

Scaltriti G. P., 1982. Osservazioni biologiche sulla Euphilippia olivina Berl. \& Silv. nel Veneto (Hom. : Coccidae). Mem. Soc. Entomol. Italiana, 60 (2), 289-297.

Scheurer R., Ruzette M. A., Fluck V., 1975. Effects of treatment with an insect growth regulator on the pear psylla (Psylla pyri L.) under field conditions. Z. Angew. Entomol., 78 (3), 313-316.

Selim A. A., 1977. Some notes on the activity of certain insects predators and parasites of the Hammam Al-Alil area. Mesopotamia $J$. Agric., 12 61), 65-73.

Sem'yanov V. P., 1981. New data on the parasites and predators of Coccinella septempunctata L. (Col. : Coccinellidae). Irud. Vsesoy. Entomol. Obshch., 63, 11-14 (in russian).

Serantes de Gonzalez H., Sierra de Nunez A., 1976. Microlophium carnosum (Buckton, 1876) (Hom. : Aphididae). Rev. Soc. Entomol. Argentina, 35 (1/4), 11-16.

Setti M., 1973. Ricerche sulla attivita di alcune specie di sirfidi (Diptera) predatori di afidi del melo. Boll. Ist. Entomol. Univ. St. Bologna, 30, 103-132.

Shalamberidze N., 1980. The pear psyllid. Zashch. Rast., 7, 27 (in russian).

Shands W. A., Simpson G. W., Muesebeck C. F. W., Wave H. E., 1965. Parasites of potato-infesting aphids in northeastern Maine. Bull. Me agric. Exp. Stn, T 19, 77 p.

Shi D. S., 1982. Studies on the hymenopterous parasite complex and its fluctuation on the cotton aphid (Aphis gossypii Glover) in Shangai. Contrib., Shangai Inst. Entomol., 1, 215-219 (in chinese).

Shlyakhovoi N. A., Bobonich V. M., 1975. Natural regulators of the numbers of pests. Zashch. Rast., 5, 31 (in russian).

Shurovenkov B. G., 1981. Indigenous natural enemies of rose sowthistle. Zashch. Rast., 10, 54-55 (in russian).

Sidlyarevich V. I., 1965. The importance of predacious mites and bugs in reducing the numbers of Metatetranychus ulmi Koch in the Byelorussian SSR. Trud. Inst. Zashch. Rast., 24, 240, 247 (in russian).

Sidlyarevich V. I., 1968. Predacious bugs of the families Anthocoridae and Miridae, their biology and useful activities in the orchards of Byelorussia, p. 256-266. In : Zimin L. S. (edit.), The biological method of plant protection. Trud. vses. Zashch. Rast., 31, $448 \mathrm{p}$. (in russian).

Sinha T. B., Pandey R. K., Rajendra Singh, Tripathi C. P. M.,
Kumar A., 1982. The functional response of Coccinella septempunctata L., a coccinellid predator of mustard aphid Lipaphis erysimi Kalt. Entomon, 7 (1), 7-10.

Skanland H. T., 1981. Studies on the arthropod fauna of a Norwegian apple orchard. Fauna Norvegica, B, 28 (1), 25-34.

Slabospitskii A. I., 1980. Insect enemies of cabbage pests. Zashch. Rast., 5, 23 (in russian).

Smetanin A. N., 1970. Entomophagous arthropods in seed producing forest area. Zashch. Rast., 15 (1), 48 (in russian).

Smith J. G., 1976. Influence of crop background on natural enemies of aphids on Brussels sprouts. Ann. Appl. Biol., 83 (1), 15-29. Smith J. W., Scott W. P., Parencia C. R., 1978. Predator-prey ratios for control of Heliothis species on cotton, p. 111-113. In Brown J. M. (edit. ), 1978 Proceedings, Beltwide Cotton Production Research Conferences, Jan. 9-11, 1978, Dallas, Texas, iv + $225 \mathrm{p}$.

Smith R. W., Whittaker J. B., 1980. Factors affecting Gastrophysa viridula populations (Col. : Chrysomelidae) in different habitats. $J$. Anim. Ecol., 49 (2), 537-548.

Smolarz S., 1970. The biology of the mealy plum aphid Hyalopterus pruni (Geoff.) (Hom. : Aphidoidea). Polskie Pismo Entomol., 40 (2), 287-328 (in polish)

Solomon M. G., 1982. Phytophagous mites and their predators in apple orchards. Ann. Appl. Biol., 101 (1), 201-203.

Sotherton N. W., 1982. Predation of a chrysomelid beetle (Gastrophysa polygoni) in cereals by polyphagous predators. Ann. Appl. Biol., 101 (1), 196-199.

Soylu O. Z., 1980. Investigations on the biology and control of citrus whitefly Dialeurodes citri Ashmead, injurious in citrus orchards in the mediterranean region of Turkey. Bitki Koruma Bül., 20 (1/4), 36-53 (in turkish).

Soylu O. Z., Urel N., 1977. Investigations on the parasites and predators of insects injurious to citrus orchards in the region of South Anatolia. Bitki Koruma Bül., 17 (2/4), $77-112$ (in turkish).

Stary P., 1970. Host life-cycle and adaptation of parasites of the sycamore aphid, Drepanosiphum platanoides (Schrank) in central Europe. Acta Entomol. Bohemoslov., 67 (6), 351-359.

Steiner H., 1974. Carabidae, Staphylinidae, Cantharidae, p. $122-$ 124. In: Les organismes auxiliaires en verger de pommiers. $O I L B / S R O P$, broch. 3, 242 p.

Stimmel J. F., 1982. Seasonal history of the white peach scale, Pseudaulacaspis pentagona (Targ.-Tozz.) (Hom. : Diaspididae) in northeastern Pennsylvania. Proc. Entomol. Soc. Washington, 84 (1), 128-133.

Straka F., 1976. Biological and economic effectiveness of aphidophagous enemies of the green cabbage aphid (Brevicoryne brassicae L.). Rast. Nauka, 4, 82-91 (in bulgarian)

Sugonyaev E. S., Babaev T., 1978. On the chalcidoid (Hym. : Chalcidoidea) parasites of the false scales (Hom. : Coccoidea) in Tadzhikistan. Entomol. Obozr., 57 (1), 148-167 (in russian).

Sukhoruchenko G. I., Smirnova A. A., Vikar E. V., Kapitan A. I., 1981. The effects of pyrethroids on arthropods of the cotton agrobiocoenosis. Entomol. Obozr., 60 (1), 5-15 (in russian).

Summy K. R., Gilstrap F. E., Corcoran S. M., 1979. Parasitization of green-bugs and corn leaf aphids in west Texas. Southwestern Entomol., 4 (3), 176-180.

Sunderland K. D., 1975. The diet of some predatory arthropods in cereal crops. J. Appl. Ecol., 12 (2), 507-515.

Sunderland K. D., Vickerman G. P., 1980. Aphid feeding by some polyphagous predators in relation to aphid density in cereal fields. J. Appl. Ecol., 17 (2), 389-396.

Swirski E., 1954. The bionomics of the pear psylla, Psylla pyricola Foerst. in Israel. Ktavim (Engl. edn), 4 (4), 61-68

Szabo S., Szentkiralyi F., 1981. Communities of Chrysopidae and Hemerobiidae (Neuroptera) in some apple orchards. Acta Phytopathol. Acad. Sci. Hungaricae, 16 (1/2), 157-169.

Takaoka I., 1975. Ecological studies on aphid and their natural enemies, p. 1-8. In : Yasumatsu K., Mori H. (edit.), Approaches to biological control. Tokyo, Japan: Japanese Committee for the International Biological Program, University of Tokyo Press, viii + $142 \mathrm{p}$.

Talati G., Butani P. G., 1979. Predatory capacity of Coccinella septempunctata on groundnut aphid. Indian. J. Plant Prot., 7 (1), 107. 
Talhouk A. S., 1977. Contribution to the knowledge of almond pests in East Mediterranean countries. VI. The sap-sucking pests. $Z$. Angew. Entomol., 83 (3), 248-257.

Talitskii V. I., 1966. Hymenoptera that are parasites of the pear sucker (Psylla pyri L.) in Moldavia. Trudy moldav. nauchno-issled. Inst. Sadov. Vinogr. Vinod., 13, 191-221 (in russian).

Tanke W., 1976. Bemerkungen zur Dauerzucht von Epistrophe balteata Deg. (Dipt. : Syrphidae). Nach. Deutsch. Pflanz., 28 (4), 5556.

Tawfik M. F. S., Ata A. M., 1974. The life-history of Orius laevigatus (Fieber) (Hem. : Anthocoridae). Bull. Soc. Entomol. Egypte, 57, 145-151.

Tawfik M. F. S., Abul-Nasr S., Saad B. M., 1974a. On the feeding habits of Scymnus interruptus Goeze (Col. : Coccinellidae). Bull. Soc. Entomol. Egypte, 57, 41-54.

Tawfik M. F. S., Abul-Nasr S., Saad B. M., 1974b. The biology of Scymnus interruptus Goeze (Col. : Coccinellidae). Bull. Sac. Entomol. Egypte, 57, 9-26.

Tedders W. L., Angalet G. W., 1981. Colonization of Coccinella septempunctata L. in Georgia. J. Georgia Entomol. Soc., 16 (1), 47-53.

Teodorescu I., 1980. Beneficial insect fauna (predators) in the woods of northern Oltenia. St. Cercetari Biol., Biol. Anim., 32 (1), 3-6 (in rumanian)

Thalji R., 1981. Natural enemies of the aphid Brachycaudus helichrysi Kalt. (Hom. Aphididae), a pest of sunflower in Vojvodina. Zastita Bilja, 32 (2), 147-153 (in Yugoslavian).

Thontadarya T. S., Bhumannavar B. S., Govindan R., 1976. Parasitization of the safflower aphid by Aphidencyrtus aphidivorus (Meyr) (Hym. : Encyrtidae). Current Science, 45 (22), 811-812.

Thontadarya T. S., Rao K. J., Awaknavar J. S., 1979. Addition to the list of insects that predate the sorghum earhead midge Contarinia sorghicola (Coq.). Current Research, 8 (4), 64-65.

Thygesen T., Esbjerg P., Eiberg H., 1973. Fireblight transmission by insects. Tidsskrift Plant., 77, 324-336 (in danish).

Togoshi I., 1976. Insect community associated with a large chestnut aphid (Hem. : Aphididae). (Insect fauna of chestnut orchards in Ishikawa Prefecture II). Mushi, 49 (9), 87-93.

Tremblay E., 1968. Osservazioni sui punteruoli della canapa ( $\mathrm{Col}$. Curculionidae). Note morfologiche, biologiche e lotta chimica. Boll. Lab. Entomol. agrar. Filippo Silvestri, 26, 139-190.

Tremblay E., 1969. Il controllo del Siphoninus phillyreae (Haliday) in Campania. Studi del gruppo di lavoro del C.N.R. per la lotta integrata contro i nemici animali delle piante : XL. Boll. Lab. Entomol. Agrar. Filippo Silvestri, Portici, 27, 161-176.

Tsachev S., 1972. The integrated control of the cabbage aphid. Rast. Zashch., 20 (7), 32-34 (in bulgarian).

Tsachev S., 1978. The mussel scale of apple and its parasites. Rast. Zashch., 26 (7), 26-28 (in bulgarian).

Tsybul'skaya G. N., Kryzhanovskaya T. V., Pham van Lam, 1977. Neuropteroides inhabiting windbreaks in the Kiev region. Entomol. Obozr., 56 (4), 758-761 (in russian).

Upadhyay V. R., Kaul C. L., Talati G. M., 1981. Seasonal incidence of aphid, Dactynotus carthami and coccinellids in correlation to weather conditions. Indian J. Plant Prot., 8 (2), 117-121,

Usda, 1980. A mirid bug (Deraeocoris ruber). New Jersey, new state record. Cooperative Plant Pest Report, 5 (31), 585.

Varvara M., Patrascanu E., Sava L., 1982. Investigations on the biology, ecology and the economic importance of the predacious insect Coccinella septempunctata L. in Moldavia. Analele Stiintifice de Universitatii « Al. I. Cuza » din Iasi, Biologie, 28, 95-98.

Vereshchagina V. V., 1981. An experiment on the integrated protection of apple. Zashch. Rast., 1, 34-35 (in russian).

Vidano C., Arzone A., Meotto F., 1977/78. Fitofagi preoccupanti di attualità in frutteti piemontesi. Annali Accad. Agric. Torino, $120,65-78$.

Viggiani G., 1971. Osservazioni biologiche sul Miride predatore Deraeocoris ruber (L.) (Rhynchota, Heteroptera). Boll. Lab. Entomol. agrar. Filippo Silvestri, 29, 270-286.

Viswanathan T. R., Ananthakrishnan T. N., 1974. Population fluctuations of 3 species of anthophilous Thysanoptera in relation to the numerical response of their predator, Orius minutus L. (Hem. : Anthocoridae). Current Science, 43 (1), 19-20.
Vrabl S., Matis G., 1977. A contribution to the knowledge of the biology of the pear psyllids (Psyllidae, Homoptera) in Slovenia, and the possibilities of its control. Zastita Bilja, 28 (1), 41-52.

Wadhi S. R., Parshad B., 1980. Some new records of Coccinellidae from Nepal Himalayas. Bull. Entomol., 21 (1/2), 144-147.

Wagner E., Weber H. H., 1964. Hétéroptères Miridae. In : Faune de France, 67, 589 p., Féd. Fse Soc. Sci. Nat., Paris.

Walker A. L., Bottrell D. G., Cate J. R. Jr., 1973. Hymenopterous parasites of biotype $\mathrm{C}$ greenbug in the high plains of Texas. Ann. Entomol. Soc. Am., 66 (1), 173-176.

Westigard P. H., 1979. Integrated pest management of insects and mites of pear, p. 151-202. In : Pest Management programs for deciduous tree fruits and nuts. D. J. Boethel \& R. D. Eikenbary edit., Plenum Press, N. Y., $256 \mathrm{p}$

Westigard P. H., Gentner L. G., Berry D. W., 1968. Present status of biological control of the pear psylla in southern Oregon. J. econ. Entomol., 61 (3), 740-743.

Whalon M. E., Elsner E. A., 1982. Impact of insecticides on Illinoia pepperi and its predators. J. econ. Entomol. 75 (2), 356-358.

Whalon M. E., Parker B. L., 1978. Immunological identification of tarnished plant bug predators. Ann. Entomol. Soc. Am., 71 (3), 453-456,

Wheeler A. G. Jr., Stimmel J. F., 1979. Bean aphid on ornamental Euonymus : seasonal history and damage. Melsheimer Entomol. Series, 27, 26-29.

Wiackowski S. K., Wiackowska I., 1968. Investigations on the entomofauna accompanying aphids occuring on fruit trees and bushes. Polskie Pismo entomol., 38 (2), 255-283.

Wilde W. H. A., 1962. Bionomics of the pear psylla, Psylla pyricola Foerster, in pear orchards of the Kootenay Valley of British Columbia, 1960. Can. Entomol., 94, 845-849.

Wille H. P., 1950. Untersuchungen über Psylla pyri L. und andere Birnblattsaugerarten im Wallis. Promotionsarb. eidg. tech. Hochsch. Zürich, $113 \mathrm{p}$

Wilson L. T., Gutierrez A. P., 1980. Within-plant distribution of predators on cotton : comments on sampling and predator efficiencies. Hilgardia, 48 (2), 3-11.

Witsack W., 1971. Zur Biologie und Okologie von Synharmonia lyncea Ol. (Col. : Coccinellidae). Entomol. Nachrichten, 15 (2), 1620.

Wnuk A., 1972. Studies on the species composition of predacious hoverflies (Syrphidae, Diptera) occuring in aphid colonies on fruit trees and bushes. Polskie Pismo Entomol., 42 (1), 235-247 (in polish).

Wnuk A., 1977. Evaluation of the effectiveness of Episyrphus balteatus (Deg.) (Dipt. : Syrphidae) in the control of Aphis pomi Deg. (Hom. : Aphididae). Polskie Pismo Entomol., 47 (4), 755-760 (in polish).

Wojnarowska P., 1962. Psylla pyrisuga Foerst. - a pest of pears. Prace nauk. Inst. Ochr. Kost., 4 (2), 153-177.

Wojnarowska P., Baranowna I., Lipowa I., 1960. Psylla pyri L. a pest of pears. Prace nauk. Inst. Ochr. Rosl., 2 (1), 143-161 (in polish).

Wu Y., Li Y. P., Jiang D. Z., 1981. Integrated control of cotton pests in Nanyang region. Acta Entomol. Sinica, 24 (1), 34-41 (in chinese).

Yakhontov V. V., 1929. List of pests of economic plants in the region of Bokhara and their parasites and insect predators. Trudui Shirabud. opuitn. s-kh. Sta. otdel Zashch. Rast., 2, 46 p. (in russian)

Yarkulov F. Y., 1978. A test of the biological protection of cucumbers in the Maritime Region. Zashch. Rast., 6, 9 (in russian).

Yastrebov I. O., 1979. Enemies of cabbage pests. Zashch. Rast., 1, 34 (in russian).

Zeleny J., 1978. Les fluctuations spatio-temporelles des populations de Névroptères (Planipennia) comme élément indicateur de leur spécificité, p. 359-366. In : Colloque Franco-Tchécoslovaque sur la «Spécificité des entomophages » (C. R. Antibes) (26 sept. au I ${ }^{\text {er }}$ oct. 1977) (INRA). Ann. Zool. Ecol. Anim., 10 (3), 315-459.

Zeletzki C., Rinnhofer G., 1966. Uber Vorkommen und Wirksamkeit von Praedatoren in Obstanlagen I. Eine Mitteilung über Ergebnisse zweijähriger Klopffänge an Apfelbäumen. Beitr. Entomol., 16 (5/6), 713-720. 
Zhang C. R., Feng S. C., Shi G. Y., Li Y., 1982. A preliminary report on Orius minutus L. - an important predator of injurious mites in apple orchards. Kunchong Zhishi, 19 (4), 13-15 (in chinese).

Zheng L. Y., 1982. Two new species of Orius Wolff from China (Hem. : Anthocoridae). Acta Entomol. Sinica, 25 (2), 191-194 (in chinese).
Ziarkiewicz T., 1976. Heteroptera occuring in an agrocoenosis of potato in Felin near Lublin in 1971-73. Polskie Pismo Entomol., 46 (3), 483-487 (in polish).

Ziarkiewicz T., Kozlowska A., 1973. Contribution to the knowledge of the species composition of hoverflies (Syrphidae, Diptera) occuring among colonies of aphids on ornamental shrubs. Polskie Pismo Entomol., 43 (3), 621-626 (in polish). 